\title{
Perichondrial arthroplasty of the knee
}

Citation for published version (APA):

Homminga, G. N. (1989). Perichondrial arthroplasty of the knee. [Doctoral Thesis, Maastricht University]. Rijksuniversiteit Limburg. https://doi.org/10.26481/dis.19891109gh

Document status and date:

Published: 01/01/1989

DOI:

10.26481/dis.19891109gh

Document Version:

Publisher's PDF, also known as Version of record

\section{Please check the document version of this publication:}

- A submitted manuscript is the version of the article upon submission and before peer-review. There can be important differences between the submitted version and the official published version of record.

People interested in the research are advised to contact the author for the final version of the publication, or visit the DOI to the publisher's website.

- The final author version and the galley proof are versions of the publication after peer review.

- The final published version features the final layout of the paper including the volume, issue and page numbers.

Link to publication

\footnotetext{
General rights rights.

- You may freely distribute the URL identifying the publication in the public portal. please follow below link for the End User Agreement:

www.umlib.nl/taverne-license

Take down policy

If you believe that this document breaches copyright please contact us at:

repository@maastrichtuniversity.nl

providing details and we will investigate your claim.
}

Copyright and moral rights for the publications made accessible in the public portal are retained by the authors and/or other copyright owners and it is a condition of accessing publications that users recognise and abide by the legal requirements associated with these

- Users may download and print one copy of any publication from the public portal for the purpose of private study or research.

- You may not further distribute the material or use it for any profit-making activity or commercial gain

If the publication is distributed under the terms of Article $25 \mathrm{fa}$ of the Dutch Copyright Act, indicated by the "Taverne" license above, 


\section{PERICHONDRIAL ARTHROPLASTY OF THE KNEE}

\section{Proefschrift}

ter verkrijging van de graad van doctor aan de Rijksuniversiteit Limburg te Maastricht, op gezag van de Rector Magnificus, Prof. Dr. F.I.M. Bonke, volgens het besluit van het College van Dekanen, in het openbaar te verdedigen op donderdag, 9 november 1989 om 16.00 uur

door

George Nicolaas Homminga

geboren te Franeker in 1952 
Promotor: Prof. dr. A. J. van der Linden

Beoordelingscommisssie:

Prof. dr. G. Kootstra,

Prof. dr. J. Arends,

Prof, dr. J. Drukker,

Prof, dr. $J$ van Engelshoven.

Prof. dr. J. K. van der Korst, Amsterdam.

CIP-DATA Koninklijke Bibliotheek, Den Haag

Homminga. George Nicolaas

Perichondrial arthroplasty of the knee/George Nicolaas Homminga, Maastricht:

Datawyse. 1II. Thesis Maastricht. With ref. -With summary in Dutch.

ISBN 90-5291-007-3

SISO 605.18 UDC 616-089.8:616.72 (043.3)

Subject heading: perichondrial arthroplasty : knees.

Publication of this thesis was made possible by the financial support of the following companies:

BOURNONVILL PHARMA, IMMUNO, MERCK, ORTOMED, OUDSHOORN, SOMAS,

STOPLER, van STRATEN, STRYKER, WEST.

Druk: DataWyse Maastricht/Krips repro Meppel

Omslag en Vormgeving / DTP: Guus van Rooy, Maastricht 
Every change of form brings about a change of function

Charles Darwin (1859) in "On the origin of species by means of natural selection." 



\section{CONTENTS \\ "PERICHONDRIAL ARTHROPLASTY OF THE KNEE".}

CHAPTER ONE:

CHAPTER TWO:

CHAPTER THREE:

3.1 Etiology

3.2 Types of lesions

3.3 The natural course of cartilage lesions

3.4 Inhibition and stimulation of cartilage repair

CHAPTER FOUR:

4.1 Anatomy and histology

4.2 The chondrogenic capacity of perichondrium

4.3 In vitro formation of cartilage generated from perichondrium

4.4 Orientation of the perichondrial graft

4.5 Biochemical properties of cartilage generated from a perichondrial graft

4.6 Long term results of perichondrial grafting

4.7 Biomechanical properties

4.8 Technical aspects

4.9 Clinical application

4.10 Summary

4.11 Conclusions and considerations

CHAPTER FIVE:

Fibrin glue

5.1 Introduction

5.2 Composition and mode of action

5.3 Bonding capacity

5.4 The use of fibrin glue in the fixation of osteochondral fragments.

5.5 Biocompatibility and risk of contamination

5.6 Summary 
CHAPTER SIX:
6.1. Introduction
6.2 Materials and methods
6.3 Results
6.4 Conclusions

CHAPTER SEVEN: The chondrogenic capacity of adult human perichondrium

7.1 Introduction

7.2 Material and methods

7.3 In vitro culture technique

7.4 Histology

7.5 Autoradiography

7.6 Results

7.7 Histology of explant before culture

7.8 Histology after 7 days of culture

7.9 Histology after 10 days of culture

7.10 Results of autoradiography

7.11 Discussion

CHAPTER EIGHT: Perichondrial arthroplasty of the human knee

8.1 Introduction

8.2 Materials and methods

8.3 Surgical procedure

8.4 Results

CHAPTER NINE:

8.5 Discussion

CHAPTER TEN:

Summary

Samenvatting

ACKNOWLEDGEMENTS

CURRICULUM VITAE 


\section{Introduction}

Damaged articular cartilage of the knee is a common cause of pain and discomfort. With the increasing use of the arthroscope the diagnosis is made more often and at an earlier stage. Gillquist et al. (1977) found in 10 percent and Dehaven (1980) in 6 percent of acute knee injuries significant damage of the articular cartilage of the knee. Most patients with a cartilage lesion of the knee do not mention a specific trauma: there has been a slow increase of symptoms leading to an unacceptable level of pain or level of activity.

Pain during and after exercise, intermittent swelling, giving way and signs of locking are the most frequently uttered complaints. Especially when the cartilage is partially inflicted, the diagnosis may be delayed (Johnson-Nurse and Dandy 1985).

Spontaneous healing of lesions of hyaline cartilage is limited. Moreover these lesions have a tendency to develop to arthrosis (Ficat et al. 1978). Conservative treatment such as restriction of activities, muscle strengthening and knee stabilizing exercises, physiotechnical applications or antalgetics may relieve the symptoms. In most cases full loading activities will remain troublesome and will interfere with the patient's job and daily life activities. This not only causes discomfort to a person's life because of pain and functional impairment, but it may also have serious consequences for his occupational and social status (Hopkinson et al. 1985).

Chondral lesions of the knee have been treated surgically in animal experiments by placing loose chondrocytes of the epiphysis into the defect (Bentley and Greer 1971), by autologous transplantation of apophyseal cartilage (Benum 1974), by costal cartilage (Hjertquist and Lempberg 1969), by periost (Rubak et al.1982, Niedermann et al. 1985, O'Driscoll and Salter 1984) and by osteochondral allografts (Lane et al. 1977, Cziltrom et al. 1986). In experimental studies the best results haven been achieved with periost, autologous cartilage and osteochondral grafts. Interposing structures like skin, dura, fascia, fat, of artificial tissues like collagen sponge (Speer et al. 1979) and carbon fibres (Minns et al. 1982) have been used to fill cartilage defects.

Hernborg and Nillson (1977) studied the natural course of gonarthrosis and 
concluded that the course of the disease is usually unfavourable. More than $50 \%$ of the patients did not improve with time passing but got more symptoms with increasing roentgenological signs of arthrosis.

The most advocated and applied clinical treatment of cartilage lesions is to excise the loose and sick cartilage and to drill the subchondral bone according to Pridie (1956). The application of autologous cartilage transplantation is limited by the availability of articular cartilage. In 1985 Niederman et al. reported excellent results of periostal grafting in 4 patients with osteochondritis dissecans in the knee. The clinical experience with this technique is limited. The use of osteochondral allografts in patients is confined to younger patients (Oakeshott et al. 1988) with traumatic articular cartilage lesions (McDermott et al. 1985) and restricted to those who tolerate the rehabilitation regime, which includes 12 months in an ischial-bearing weight relieving long-leg caliper.

Osteotomies and arthroplasties are now being used to an increasing extent for the treatment of gonarthrosis. High tibial osteotomies are indicated in unicompartimental arthrosis with varus or valgus deformity. After a longterm follow-up study of 60 knees Marmor (1988) concluded that unicompartimental knee arthroplasty may be a good alternative, especially in elderly patients.

Nowadays total replacement of the knee with an artificial prosthesis is a common procedure in advanced gonartrosis. The major causes of failure in total knee arthroplasty are loosening, instability, sepsis, extensor mechanism power loss, poor range of motion, bone fractures and prosthesis fracture. Apart from these local problems, general problems may occur in artificial implants: corrosion, allergic reactions, long-term toxicity, and the possible induction of neoplasma (Hamblen and Carter 1984).

In summary, there are three main reasons to look for methods of biological repair of cartilage lesions or arthrosis of the knee:

-The natural repair process is insufficient and the natural course is unfavourable.

-Unsatisfactory results of the current treatment of localised cartilage defects.

-The implantation of artificial knee joints gives too many complications, especially in the younger patient.

Our attention was drawn to the structure which is responsible for appositional growth of cartilage throughout fetal life and-at a slower rate-during the growth period in childhood and puberty i.e. perichondrium.

In animal experiments it was established that perichondrium, when placed in the knee joint, develops into hyaline cartilage. The qualities of this newly formed cartilage are histologically "visco-elastically (Woo et al. 1987), biochemically (Amiel et al. 1985) and at long term (Amiel et al. 1988) comparable with normal hyaline cartilage. 
In clinical practice perichondrial arthroplasty has only been applied in smaller joints. For application in larger joints like the knee, graft fixation is the major problem. Fibrin glue seems to be suitable for temporary fixation of the perichondrial graft. It has proven to be effective in adhering other tissues without negative side-effects. Moreover it is biodegradable within two weeks time (Staindl and Galvan 1982).

The purpose of this thesis is:

-To observe and to describe the development of perichondrium when placed in a chondral defect of the rabbit knee, and to compare the result with that of a non-treated cartilage defect in the other knee.

-To test the effectiviness of fibrin glue in fixing perichondrium to the subchondral bone of an artificially created cartilage defect of the rabbit knee.

-To describe the technique of perichondrial grafting in man and to study the development of the graft by arthroscopy until one year after operation.

-To study the change in clinical condition by perichondrial arthroplasty of the knee.

-To study and describe the histological characteristics of the tissue derived from a perichondrial graft.

-To describe the radiological changes of the knee after perichondrial grafting of a cartilage defect. 


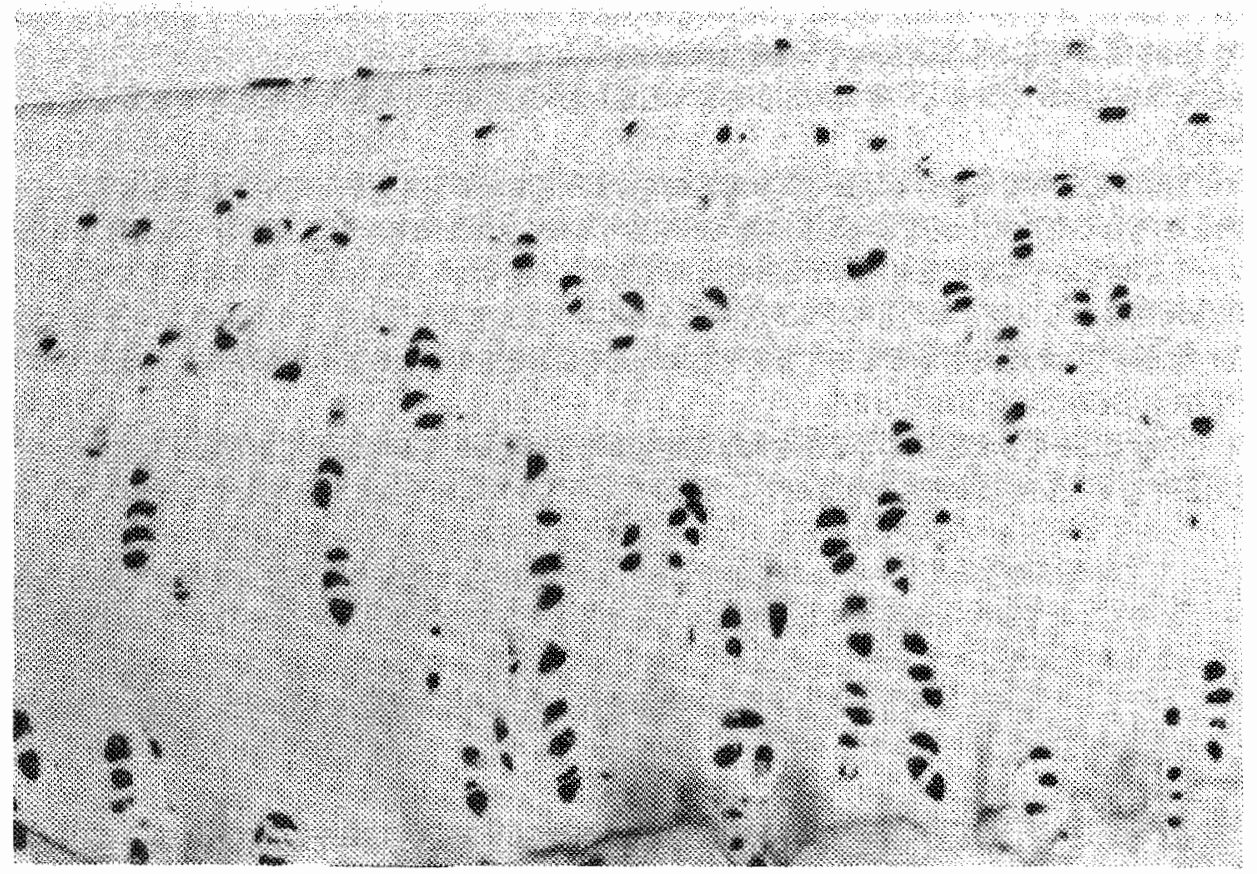

Figure 2.1.

Normal articular cartilage with its various layers. See text. HE $\times 144$. 


\section{Articular cartilage}

Articular cartilage is a specialized form of connective tissue. It has unique histological (Figure 2.1), mechanical and biochemical properties, and the tissue is suitable for its role as a shock absorber and a gliding surface for the synovial joint.

in the human embryo the first indication of joint formation occurs at embryonic size of about $12 \mathrm{~mm}$. The indication of the development of a future joint cavity is seen at the interzone, a remnant of unchondrified blastemal cells remaining between the cartilages (Streeter 1949). When the fetus has reached the size of $21 \mathrm{~mm}$, the interzones of some of the joints have lost their homogenous character. The chondrogenous layer of the two denser zones of cells, parallel to the surface of the cartilage skeleton, are peripherally continuous with the perichondrium. In this way a complete investment for the end of each skeletal structure is formed. When the fetus is $34 \mathrm{~mm}$, the cavity of the major joints is well formed and contains a number of recognizable structures. The cartilage adjacent to the ossification nucleus is calcified and gradually fades into normal hyaline cartilage. The cells begin to enlarge and one frequently sees two cells in one lacuna. When the skeleton reaches maturity, the cartilage which was provisionally calcified, is limited by a denser wavy, granular line of deep-blue staining material seen on the haematoxylin-eosin sections, called the "tidemark" (Fawn and Landells 1953). The bone subadjacent to the calcified cartilage developes into a continuous lamellar plate seen in the gross specimen as the subchondral bone.

Articular cartilage is referred to as hyaline because of its homogenous, glossy appearance in gross observation. Young cartilage looks bluishwhite; in adults it has a yellow-white colour. Normally the surface is smooth and the consistency is solid.

By light microscopy a homogenous structure is seen with four different zones: the superficial, gliding layer with elongated cells, lying parallel to the surface; the transitional zone with plump cells; the radial zone with round cells lined up in columns or palisades, running at right angles to the surface; and the calcified zone lying adjacent to the subchondral bone with large cells (Figure 2.1).

Stockwell (1977) studied these cells with the electron-microscope and 
found the most metabolically active chondrocytes in the transitional zone. The major characteristic of cartilage is not only its sparse cellularity but more so its remarkable "isolation" from the rest of the body. Adult articular cartilage has no nerve, blood or lymphatic supply. The matrix contains approximately $80 \%$ water, macromolecular aggregates: proteoglycans

(GAG's) and a special type of collagen, type $\mathrm{II}$, rather than the more prevalent collagen type I found in bone and tendon. The strength of cartilage depends on the retention of an aqueous proteoglycan gel within the loaded matrix and on the tensile strength of the collagen network which acts to immobilize the gel. Irreversible structure failure in cartilage is more likely to occur in the collagen fiber mesh than in the proteoglycan gel.

The mechanical properties of articular cartilage fullfill three main functiones: reduction of stresses applied to the subchondral bone; prevention of abrasion between the articulating bone extremities and provision of low friction bearing surfaces (Kempson 1979). 


\section{Damage to the articular cartilage of the knee.}

\subsection{Etiology}

Lesions of articular cartilage occur when too much force is applied to normal cartilage or when normal forces affect sick or weakened cartilage. Trauma is a major cause of cartilage damage of the knee and occurs especially in sports activities like soccer, football, rugby, basketball etc. Very often it will be combined with or preceded by lesions of the collateral or cruciate ligaments, or the medial or lateral meniscus. It may be assumed that these structures, by giving stability to the knee, give a restriction to the extent of forces that may act upon the cartilage. Another predisposing factor for cartilage damage is malalignements as in genua vara, genua valga, patella alta and baja, and a subluxating patella. The last may be caused by an abnormal form of the patella, as described by Wiberg in 1941. When it comes to a complete luxation of the patella, considerable damage may be done to the patella cartilage. Displaced chondral frag ments will become loose bodies.

Chondral fractures, with or without a shelf of bone are caused by three types of forces: compaction, shearing or avulsion.

Compaction damage results from a direct force applied perpendicularly to the joint surface. The mechanism of compaction is exemplified by a direct blow over the patella crushing the patellar cartilage against the femoral cartilage. The type of injury causing a tibial plateau fracture may, when smaller in force, cause compaction of the tibial cartilage by the convexity of the femoral condyle. The femoral part of the knee joint may be damaged by either the patella or the tibia. When the knee is forcefully extended the intercondylar facies of the medial femoral condyle knocks to the anterior horn of the medial meniscus. This leads to impaction and contusion of this part of the surface. Compression of the medial femoral condyle may also occur when axial loading is combined with extreme rotation of the lower leg (Kennedy et al. 1966).

Shearing forces are the result of a blow glancing almost tangentially to the articular surface. The patellar luxation is an example of this kind of mechanism. The cartilage of the patella may be sheared off by the quadriceps 
tendon, the medial retinaculum or the patella tendon. Sometimes the cartilage of the femoral condyle is knocked off "in most cases with a small fragment of bone.

Avulsion of a piece of cartilage, with or without a piece of bone, is caused, for example, by forceful traction of the anterior cruciate ligament on the tibial tuberosity. The posterior ligament may avulse from the medial femoral condyle. The medial retinaculum may separate a plece of the patellar cartilage when it is luxated.

The studies of Landells (1957) have clarified that forces applied to articular cartilage have their main impact on the junction of calcified and uncalcified cartilage. In adolescents there is little calcified cartilage and a strong bond between cartilage and bone, so the tangential forces are directed to the underlying bone. Therefore this age group has a high incidence of osteochondral fractures whereas in adults pure chondral fractures are more frequent (Matthewson and Dandy 1978).

Osteochondritis dissecans, another frequent cause of chondral lesions, is believed to be the result of a trauma (Rosenberg 1964, O'Donoghue 1966). Infarction of the subchondral bone, visible on a X-ray, will lead to insufficient support of the overlying cartilage. Although the nutrition of the cartilage takes place through the synovial fluid, it will be more susceptible to forces as it depends on the mechanical properties of its bony bed (Radin and Rose 1986). In other cases the overlying cartilage will become separated from its bed, forming a loose body in the joint; a full-thickness cartilage defect will remain, exposing the subchondral bone.

Minor contusions may also damage the cartilage, foilowed by degeneration and necrosis of chondrocytes as described by Ficat et al. in 1978. These chondral contusions may lead to cartilage defects and eventually to arthrosis.

Chondromalacia patellae is a distinct clinical entity, characterized by pain in the anterior part of the knee. Trauma, osteochondritis or malalignement may play a role in the etiology. In many cases the cartilage of the patella is macroscopically intact. This is best demonstrated with the arthroscope (Bentley elt al.1983). A hook will demonstrate the very soft consistency. Also normal forces may damage the articular structure of the patella, especially the medial facet. This will lead to large surfaces of fibrillation, chondral flaps and in the end to complete full thickness defects, exposing the underlying subchondral bone.

In the case of crystalarthropathy like chondrocalcinosis, pseudogout and gout, the cartilage weakens not only by the changed metabolism, but ais by the reactive response of the synovium and the changed consistency of the synovial fluid. After a septic or reactive arthritis and traumatic or postoperative haemarthros of the knee the articular cartilage will be more susceptible to damage. This could be explained by diminished muscular control, due to a temporary loss of propriocepsis. 


\subsection{Different types of cartilage lesions}

Johnson-Nurse and Dandy (1985) reported on 76 knees with fracture separation of the articular cartilage. They made a distinction between full- and partial-thickness lesions. They assessed that full-thickness lesions extended to the subchondral bone and occurred most commonly in the third decade of life. Partial-thickness lesions were found more frequently in the fourth decade, and osteochondral fractures in adolescents or young adults. Morscher (1979) described three types of impression fractures of the cartilage of the femoral condyle after trauma:

In the "Kantenimpressionen" the subchondral bone is impressed, together with its overlying cartilage, forming a step in the articular surface. The same phenomenon is seen in a true intra-articular fracture.

In the "federnde" bonecartilage impression type, the cartilage surface stays smooth but the underlying subchondral bone is impressed.

The "muldenformige" impression type shows a depression or thinning of the cartilage. This is caused by a direct force which is mainly directed at the lateral part of the medial femoral condyle. Contusion of hyaline cartilage may lead to softening and change of colour from white to yellow-brown. Outerbridge (1961) graded cartilage lesions of the patella mainly to the extent of the involvement of the cartilage:

Grade I: fibrillation or fissuring in an area of less than $0.5 \mathrm{~cm}$.

Grade 2: fibrillation or fissuring in an area of $0.5-1 \mathrm{~cm}$.

Grade 3: fibrillation or fissuring in an area of $1-2 \mathrm{~cm}$.

Grade 4: fibrillation or fissuring in an area exceeding $2 \mathrm{~cm}$ without exposure of the subchondral bone.

The macroscopic appearance of articular cartilage lesions, as seen with the arthroscope, is well recognized but a hook should always be used to asses the exact extension of the lesion (Dzioba 1988).

Bauer and Jackson (1988) developed a classification scheme primarily based on arthroscopic appearance:

Type one:

The linear-crack lesion is usually split-thickness but sometimes down to the subchondral bone. In the last case it resembles the "Kantenimpression" as described by Morscher.

Type two:

The stellate-fracture type. Here a system of diverging cracks is apparent, often with a central flaking of cartilage.

Type three:

The flap type represents a flap of articular cartilage, lifted off at its apex but attached at its base. These lesions are usual triangular. 
Type four:

In the crater type a piece of cartilage, usually full-thickness, is missing.

Type five:

The fibrillation type is characterized by a fine, fibrillated appearance. There may be partial and full-thickness defects, which should be established by using a hook.

Type six:

The degrading-type lesion is degenerative and soft with major and minor pieces of cartilage breaking away from the surface.

An exact description of cartilage lesions is essential when the results of the natural course and different ways of treatment must be evaluated and compared. In our opinion the classification of Bauer and Jackson meets this condition.

In some cartilage lesions, especially in osteochondritis dissecans and long existing degenerative lesions, the subchondral bone plate is missing. This may have a considerable influence on the progression of arthrosis as was suggested by Radin and Rose (1986). Furthermore it may influence the development of a graft placed in the cartilage defect.

We suggest that the description of cartilage lesions should include the following four points:

1. Location

2. Type of lesion according to the classification of Bauer and Jackson.

3. Estimated extension of the lesion.

4. Presence of the subchondral bone or exposion of the cancellous bone.

\subsection{The natural course of lesions of the articular cartilage}

Wound healing of hyaline cartilage differs mainly from that of other tissues by the lack of vascularity. The response of articular cartilage to injuries has been studied extensively in animals. In most of these experiments a lesion was made by a trauma and the way of healing observed over some period of time. Despite the large data accumulated over the years there are still some controversies as to the nature of reaction of the cartilage to different types of injuries.

Hunter stated in 1743 that "from Hippocrates to the present age it is universily accepted that ulcerated cartilage is a troublesome thing and that, once destroyed, it is not repaired". In his classical article: "On the healing of wounds in articular cartilage" Redfern (1851) concluded that "wounds in articular cartilage undoutedly are capable of perfect union by the formation of fibrous tissue out of the texture of the cut surfaces". Leidy (1849), Kolliker (1853) and Paget (1853) disagreed with the qualification "perfect union" and stated that a rupture of cartilage fragments is never united. The articular cartilage lacks regenerative power; a gap in a fracture extending into a joint will be filled with tough fibrous tissue. 
Fisher (1923), Ito (1924), Shands (1931), Bennet et al. (1932), Callandruccio and Gilmer (1962), Campbell (1969) and many others came to the following conclusions:

1. The reaction of the injuried cartilage is restricted to marginal necrosis of chondrocytes and reactive "clustering". Ingrowth of undifferentiated cells seems to arise from the superficial layer.

2. Complete defects into the bone heal inconsistently either with fibrous tissue, fibrocartilaginous tissue or abnormal hyaline cartilage.

3. Apart form Calandruccio and Gilmer (1962) there is agreement about the fact that superficial defects do not heal.

Carlson (1957) created superficial defects in the central portion of the patellar cartilage of 98 adult and 21 immature rabbits. Only in two cases the defect was completely filled with hyaline cartilage. This insufficient repair reaction was confirmed by observations of Füller and Ghadially (1972) and Ghadially et al.(1977) by means of a scanning electron microscope study. They found no evidence of repair in superficial defects not in young animals and not after two years.

Ito (1924) made a full-thickness defect of the cartilage of the femoral condyle in rats. He observed that the gap filled up inconsistently with fibrous or fibrocartilaginous tissue. Puhl and Dustmann (1973) reported that deep osteochondral defects heal with granulation tissue. This connective tissue mainly contains fibrocytes, which become increasingly round and differentiate to chondrocytes. At the marginal area of the defect cluster formation was observed. These localised areas of an increased number of chondrocytes is called clumping (Campbell 1969).

Tanaka and Shirino (1971) excised the articular cartilage of the knee of male mature rabbits. In 7 to 10 months fibrocartilage was formed and in a small number of cases hyaline cartilage. To assess the functional activity of the regenerated tissue, the authors determined alkaline-phosphatase, UDPG-glycogen transferase and acid-phosphatase. All these enzymes reached a maximum after 3 to 4 months and stabilised after 8 months. As indices of energy metabolism lactate dehydrogenase as an anaerobic and succinate dehydrogenase as an aerobic enzyme were determined. Lactate dehydrogenase showed a high activity from 2 to 7 months, while succinate dehydrogenate remained at a constant low level. Only when hyaline cartilage was formed the enzyme activity reached the level as is normal in mature articular cartilage.

Mitchell and Sheppard (1976) and Furukuwa et al. (1980) studied deep cartilage defects penetrating the subchondral bone. They found that the primary fibrous repair cells change, through a process of metaplasia and differentiation, into chondrocytes. The formed matrix contains several biochemical characteristics of hyaline cartilage. Hexosamine content and galactosamine-glucosamine ratios vary in different studies but usually show a decrease. There is a shift from collagen type I to collagen type II. However, after one year the tissue appears to be more fibrous than cartilagi- 
nous, has no tangential collagen layers and an element of type-ll collagen remains.

Covenry et al. (1972) reported on a different repair reaction in defects between 3 and $9 \mathrm{~mm}$. The first, small defects, showed complete repair after three months; the larger defects formed fibrous tissue, fibrocartilage or hypercellular hyaline-like cartilage.

Nelson et al. (1988) measured contact pressures of the repair tissue of osteochondral defects in dog knees. The results suggest that the repair tissue is of poor mechanical quality and does not contribute appreciably to weight bearing.

It seems likely that the most common form of cartilage damage is caused by excessive repetitive impulse loading resulting in contusion of the articular cartilage. This type of injury was studied by Radin et al. (1978) who found a $20 \%$ decrease in hexosamine concentration and increased incorporation rates for both ${ }^{3} \mathrm{H}$ thymidine and ${ }^{35} \mathrm{~S}$ sulphate. After one week bone stiffness had increased $20 \%$. These findings suggest that the cartilage is undergoing early osteoarthritic changes. Shear and axial longitudinal loading was simultaneously applied to rabitt knee joints by Dekel and Weismann (1978). Examination of the cartilage by histology and scanning electron microscopy showed cellular degeneration, disturbed arrangement of cells with cluster formation, fibrillation and penetration of subchondral capillaries into the calcified layer of the cartilage.

Lindahl (1948) found an increased water content of the articular cartilage in osteoarthrosis. The content of collagen remains unchanged in this condition (Mankin and Lippiello 1970).

\subsection{Inhibition and stimulation of cartilage repair}

The reaction of cartilage to experimental trauma seems to be insufficient; it exhibits cell multiplication and matrix secretion. Chemical and physical factors may influence the cartilage nutrition and metabolism.

Simmons and Crismann (1965) demonstrated that salicylates prevent the usual degenerative sequelae of experimental scarification in the rabbit, permitting a considerable degree of incision healing.

Experiments with growth hormone by Crismann (1975) showed a positive effect on the healing of traumatic cartilage lesions.

In the embryonic stage mechanical stimulation is found to be of great importance among the factors determing the differentiation of mesenchymal cells (Fell 1932, Basset 1962, Hall 1969).

Movement is an essential quality of synovial joints. For its nutrition the articular cartilage of an adult completely depends on the synovial fluid (Honner and Thompson 1971). Its viscosity as well as its volume varies from joint to joint and is affected by joint disease, trauma and exercise or immobility (Davies 1967).

Olijhoek et al.(1988) studied the influence of 3 drugs on the cartilage of 
arthrotic rabbit knees. These drugs were: Trasilol( $R)$, aprotinin, an inhibitor of proteinase activity: arteparon, a composite glycosaminoglycan polysulphate and Kenacort(R), a glycocorticoid. Increased contents of glycosaminoglycans were assessed in all three cases. No positive effect could be observed on the tidemark and the grade of arthrosis. Only arteparon had a positive effect on the integrity of the articular surface.

Finsterbush and Friedman (1973), among others, studied the early changes in immobilized knee joints with the help of light and electron microscopy. After two weeks of immobilization articular cartilage cells did not appear abnormal; after 4 weeks marked proliferation of the fusiform cells in the superficial zone was present. The amount of matrix between the cells was decreased. In a number of cells in the middle zone intracytoplasmic filaments and large aggregates of glycogen were found. The changes are considered to be characteristic of traumatic arthritis. Erronen et al. (1978) immmobilized the right knee of rabbits and found a decreased glycosamineglycan (GAG) concentration and an increased synthesis rate of sulphated GAG, measured by an increased uptake of ${ }^{35}$ S sulphate.

Salter et al. (1980) observed the histological effect of continuous passive motion (CPM) on the healing of full-thickness defects in articular cartilage. The results were compared with the effects of immobilization and intermittent active motion. $44-50 \%$ of the rabbits who had CPM healed with hyaline cartilage whereas the maximum number of regeneration to hyaline cartilage in the other two groups was less than $10 \%$.

Rubak et al. (1982) immobilized the knee joints of rabbits for four weeks after periosteal grafting of cartilage defects. Under this condition only fibrous tissue developed. After remobilization the cartilage formation recovered. It was concluded that immobilization has an inhibitory effect on chondrogenesis.

O'Driscoll et al. (1984) grafted cartilage defects with periost and predominantly found bone formation and fibrous tissue in the grafts of immobilized limbs. In 59 per cent of the grafts in the limbs exposed to continuous passive motion cartilage was the predominant tissue. In 1986 the same authors reported about the biochemical analyses of cartilage defects treated with autogenous periosteal grafts with and without continuous passive motion. In the CPM group the total hexosamine content, the levels of chondroitin sulphate and keratan sulphate, and the ratio of galactosamine to glucosamine were all comparable with values of normal articular cartilage. In the groups treated with immobilization, intermittent active motion, or only two weeks of CPM, 32 to 47 per cent of the total collagen was type II, while the group with four weeks CPM had 70 per cent collagen type II. in summary it can be stated that:

Motion and especially continuous passive motion, is a stimulating factor of chondrogenesis while immobilization is an inhibitor of the regeneration of hyaline cartilage. 


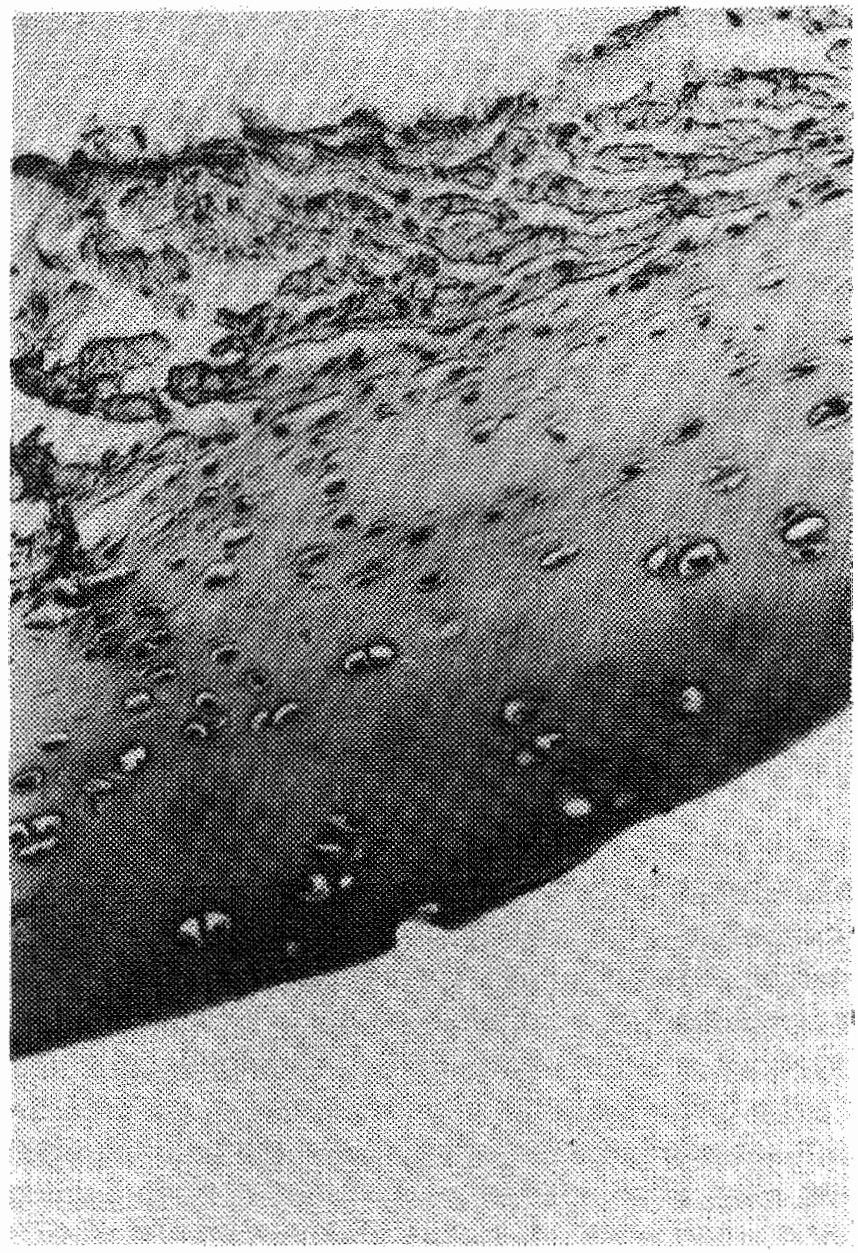

Figure 4.1.

Costal perichondrium of a rabbit. At the top the superficial layer with fibrocytes; an intermediate layer with oval cells and the layer adjacent to the cartilaginous part of the rib at the bottom. HE $\times 91$. 


\section{Perichondrium}

\subsection{Anatomy and histology}

During the embryonic period the mesenchyme surrounding the area in which cartilage develops remains closely applied to the forming cartilage and becomes its perichondrium. In the adult state the superficial part of non-articular cartilage, like that of the ears, the ventromedial part of the ribs, the tracheal and bronchial rings and the nasal septum consists of perichondrium.

Figure 4.1 shows the histological picture of costal perichondrium of a rabbit. Three different layers can be discerned:

The outer layer consists of loosely arranged flat cells, resembling fibrocytes. The intermediate layer is more compact, with cells arranged in a more orderly way. The elongated cells are placed longitudinally and contain ovalshaped nuclei.

Inside this zone there is an inner basal layer with more separated and slightly larger cells with round nuclei, resembling chondrocytes.

When dissecting the perichondrium from the cartilage, a layer of natural separation is easily found. Luxembourger et al.(1974) performed an electron microscopical study of the transitional region between perichondrium and the cartilage in the epiphyseal plate of the fetal quinea pig. He saw an oriented fibrous layer separating cartilage and perichondrium. Unlike the chondrocytes, the perichondrial cells contain a large number of irregular intracellular inclusions with vesicles.

Apart from interstitial growth, cartilage grows in extent by apposition, in which process new layers are deposited on its surface by cells of the perichondrium.

Clark and Clark (1942) microscopically observed the ears of rabbits from four to twenty months with permanent transparent chambers. After cutting a hole in the cartilage new cartilage arose from elongated motile cells. These cells contained uniformly distributed granules and became stationary and spherical. At the same time a clear homogenous substance (matrix) appeared between the cells. The regenerating "blastema" extended forward from the cut end of the old cartilage (Joseph and Dyson, 1966) and merged 
at the sides with the perichondrium. From these observations it may be concluded that the intermediate layer of the perichondrium is chondrogenic.

\subsection{The chondrogenic capacity of perichondrium}

From the midst of the 19th century scientists have tried to demonstrate the chondrogenic, i.e. the cartilage producing capacity of perichondrium. In his "Lectures of surgical pathology" Paget (1853) wrote: "In the healing of wounds of cartilage perichondrium is essential".

Archangelski (1868) concluded from his experimental study in dogs, that cartilage was produced by perichondrium.

Tizzoni (1878) reported that the repair of perichondrium covered cartilage is derived from perichondrium. Matsuoka (1904) described the regeneration of ear cartilage which was only observed when perichondrium was present. The same phenomenon was seen by Malatesta (1906) and by Haas (1914) who incised the costal cartilage of rabbits and saw the perichondrium proliferating actively to form new cartilage tissue. They concluded that perichondrium plays a decisive role in cartilage repair. Haas wrote in his conclusion: "In the regeneration of cartilage and bone it has been shown that the perichondrium and the periosteum take an analogous part in the formation of their respective new tissues. The periost is a direct derivate of the perichondrium."

Lester (1959) resected the costal cartilage subperichondrially in two patients, in order to reshape the funnel depression of the chest. One year later the depression showed itself again and at reoperation he found regeneration of costal cartilage.

Skoog et al. $(1972,1975)$ removed a segment of ear cartilage in 2 month-old rabbits. In one group a strip of perichondrium was raised as a flap and sutured back afterwards; in the other (control)group the covering perichondrium was resected together with the cartilage. In the presence of perichondrium a progressive regeneration of cartilage took place: in the control study no new cartilage developed.

Thus is the cauliflower ear, a common disfugerement that besets wrestlers, explained: new cartilage is formed in the blood-filled space between cartilage and perichondrium.

Sohn and Ohlsen (1974) used free perichondrial grafts from the ear of young rabbits to fill surgically-created tracheal defects. At the grafted sites new cartilage developed. In control areas, where a simple removal of a cartilage segment had been performed, only non-specific granulation tissue was found.

Ear perichondrium from 2 week-old rabbits, fixed in a cartilage defect of the right femur with catgut $6-0$, proved to have formed normal cartilage after one or two years (Ritsila and Alhopuro, 1975). On the control side, the bare bone and rounded edges of the defect were clearly visible.

Engkvist et al.(1975) resected the cartilage of the cavum glenoidalis down 
to cancellous bone in 30 grown-up rabbits. Perichondrium from the ear was grafted to the bare bone and anchored with sutures. In all cases regeneration of new cartilage occurred.

Wasteson and Ohlsén (1977) placed free perichondrial grafts of the ear in cartilage defects of the trachea of rabbits. On the 25th day after surgery all rabbits were injected with ${ }^{35} \mathrm{~S}$ sulphate which was incorporated in the newly formed cartilage. This favours the view that the functional properties of the regenerated cartilage are equal to those of the original tissue.

Engkvist et al. (1979) compared the chondrogenic potential of the rabbit ear with that of the rib in vivo and in vitro. In most cases of grafted or cultured costal perichondrium new cartilage was found. Grafts or cultures of ear perichondrium formed cartilage only in a minority of the cases.

Ear perichondrium has been transplanted to several other places in the body: the subcutaneous tissue in the neck, the muscles of the back and the parenchyma of the liver (Ohlsén and de la Fuente 1976, Ohlsén 1978). Cartilage was formed when a blood clot was added to the graft; none was formed by the grafts inserted without a clot.

Brent and Ott(1978) sutured perichondro-cutaneous grafts from the ear in a paravertebral skin defect in rabbits. Maruyama (1979) transplanted ear perichondrium in patients to a periostal defect of the nose, to a head defect and to the subcutaneous tissue. In the majority of these cases cartilage was formed.

In 1975 Engkvist et al. reported the use of ear perichondrium for the grafting of the subchondral bone of the glenoid of the humero-scapular joint, which was denuded of its overlying cartilage. The operated limb was amputated at wrist level to prevent weight bearing. In 12 out of 14 rabbits regeneration of cartilage occurred, whereas in 4 out of 10 small areas of mature cartilage were seen. This was a confirmation of the report of Ritsila and Alhopuro(1975): perichondrium is capable of restoring articular cartilage defects.

Rib perichondrium covering cartilage defects of femoral condyles of immature and mature rabbits formed cartilage within 13 weeks (Engkvist and Wilander 1979). Using the technique of intra-articular administration of triated thymidine, mitotic activity was found in the superficial zone of the regenerated cartilage indicating that the proliferation of cells is initiated from the perichondrium.

Engkvist and Ohlsen (1979) used free autologous perichondrial grafts to reconstruct the patellar articular cartilage in adult dogs to find out whether perichondrium can be used in high pressure surfaces. They found that after 12 months the neocartilage showed degenerative changes. In contradiction with this, Amiel (1988) found normal hyaline cartilage one year after grafting a defect of the femoral condyle. The difference in long term results may be contributed the initial period of immobilization ( 3 weeks) used in the patella group.

Skoog et al.(1975) compared cartilage formation from a perichondrial flap of 
the ear in rabbits with and without a clot of blood. With a blood clot growth of new cartilage was found in 13 out of 18 rabbits; without the use of a blood clot, the development of large amounts of cartilage was rarely observed. Ohisen (1976) placed free perichondrial grafts in different tissues of the rabbit and concluded that blood is essential for the formation of cartilage. "Blood seems to create a substrate suitable for mobilisation of the inhibited cells, resulting in a cellular migration into the culture medium".

\section{3 In vitro formation of cartilage from perichondrium}

Engkvist et al.(1979) took organ cultures of ear and rib perichondrium from 6 week old rabbits. Explants of this were removed and kept in tissue culture medium. The culture was terminated after one, two and three weeks. Chondrocytes developed from one week onwards from both ear (2 out of 5) and costal perichondrium ( 5 out of 5 ). The cells were surrounded by intercellular matrix staining with saffranin $\mathrm{O}$, indicating the presence of proteoglycans. From this study it may be concluded that loose cells taken from perichondrium (perichiondrocytes) develop to chondrocytes in a culture medium. These cells proved to have the ability to produce intercellular ground substance as is found in normal articular cartilage.

Upton et al.(1981) isolated perichondrocytes from the ear and placed the cells in a tissue culture. This was done to compare their properties with those of differentiated chondrocytes and fibroblasts from the skin. Unlike fibroblasts the survival of chondrocytes in vitro was serum independent. Rabbit ear perichondrocytes displayed characteristics in vitro more similar to chondrocytes than to fibroblasts with regard to chondroitin sulphate synthesis and incorporation of ${ }^{35} \mathrm{~S}$ sulphate.

\subsection{Orientation of the perichondrial graft}

The orientation of the perichondrial graft may influence the regeneration of cartilage. Kon (1981) compared the results of two groups of perichondrial grafting techniques for the coverage of a cartilage defect of the tibia plateau of rabbits. In the first group the graft faced the joint cavity with the chondral side which resulted in complete healing in 22 out of 25 rabbits. In the other group the fibrous (external) layer was turned to the joint cavity giving repair of the articular cartilage in 10 out 25 cases.

Kulick et al. (1984) covered the eburnated surface of the patella of rabbits with ear perichondrium. In one group they placed the graft with the "cartilage-producing surface" towards the joint cavity. In the other group it was turned towards the subchondral bone. According to their observation no difference in histologic appearance or thickness of neocartilage was found. 
Upton et al. (1981) biochemically characterized the neocartilage formed out of ear perichondrium transplanted to the patella of rabbits. Variable histological patterns were found from cartilage or fibrocartilage to fibrous tissue. Analysis documented the variability of the neocartilage. Of the two specimens which were biochemically analyzed, one showed a high hexosamine and galactosamine content and a low glucosamine/galactosamine ratio which is consistent with its histological appearance of nearly normal cartilage. The low hexosamine content and high glucosamine/galactosamine ratio of the other specimen is consistent with its fibrocartilaginous appearance.

$\begin{array}{rcr}\text { Total } & \begin{array}{r}\text { Collagen Types } \\ \text { Collagen }\end{array} & \begin{array}{r}\text { Glycosaminglycans } \\ \text { Per Cent }\end{array} \\ \text { (mg hexosamine } \\ \text { (mg/gm dry tissue) } & \text { Type I Type II } & \text { perg dry tissue) }\end{array}$

\begin{tabular}{lll|llll|lr}
\hline $\begin{array}{l}\text { Normal articular } \\
\text { cartilage of the } \\
\text { femoral condyle }\end{array}$ & $603 \pm 12$ & & - & 98 & 38 & \pm 3 \\
$\begin{array}{l}\text { Perichondrium } \\
\text { from the rib }\end{array}$ & 412 & \pm 6 & 74 & \pm 3 & 26 & \pm 3 & 7 & \pm 1 \\
$\begin{array}{l}\text { Reparative tissue } \\
\text { after perichondrial }\end{array}$ & & & & & & & & \\
$\begin{array}{l}\text { grafting } \\
6 \text { weeks }\end{array}$ & 532 & \pm 28 & 45 & \pm 4 & 55 & \pm 4 & 25 & \pm 4 \\
12 weeks & 566 & \pm 35 & 38 & \pm 4 & 62 & \pm 4 & 31 & \pm 3 \\
18 weeks & 560 & \pm 19 & 34 & \pm 3 & 66 & \pm 3 & 26 & \pm 2 \\
26 weeks & 576 & \pm 10 & 21 & \pm 2 & 79 & \pm 2 & 28 & \pm 3 \\
52 weeks & 583 & \pm 8 & 18 & \pm 2 & 82 & \pm 2 & 30 & \pm 4
\end{tabular}

TABLE 4.1. A Comparison of Biochemical Parameters of Hyaline Cartilage, Ribperichondrium and Perichondrial Grafts (Amiel et al. 1988).

Amiel et al (1985) reported the histological and biochemical results of rib perichondrial grafts for the repair of full-thickness defects of the femoral condyle of rabbits. In spite of a $50 \%$ failure rate due to an insufficient graft technique with a core of bone, they were able to determine the results of the rest of the perichondrial grafts after six and twelve weeks. A comparison was made with the values of nomal articular cartilage for the following parameters (Tabel I): Total collagen ( $\mathrm{mg} / \mathrm{g}$ dry tissue), the percentage of collagen type I or type II and the total glycosaminoglycans (hexosamine/g 
dry tissue). A significant difference in total collagen was found between perichondrium ( $412+\%-6$ ) and the perichondrial graft at six weeks ( 532 $\mathrm{mg}$ ) and twelve weeks ( $566 \mathrm{mg}$ ) and normal hyaline cartilage ( $603 \mathrm{mg}$ ). The percentage of type $1 /$ collagen increased considerably from 25 in perichondrium to 55 in the reparative tissue after six weeks and 65 per cent after twelve weeks. In normal articular cartilage the percentage of type II collagen is more than 95 per cent. The total of glycosaminoglycans increased from $7 \mathrm{mg}$ in perichondrium to $32 \mathrm{mg}$ after 6 weeks and $35 \mathrm{mg}$ after 12 weeks. Analysis showed that the values of the 6 and 12-week perichondrial grafts were statistically different $(p<0.005)$ when compared with costal perichondrium $(8 \mathrm{mg})$ and normal articular cartilage $(42 \mathrm{mg})$.

\subsection{Long term results of perichondrial grafting}

Engkvist and Ohlsen (1979) reported deterioration of the perichondrial graft, placed in a cartilage defect of the rabbit's knee, after one year.

Amiel et al. (1988) published the results of chondrogenesis of rib perichondrial grafts studied in rabbits after one year. Apart from failures due to fractures or infections the defects showed complete filling, with apparent attachment of neocartilage to the host articular cartilage at the periphery. Histologically the neocartilage showed a mature appearance with maintenance of a hyaline cartilage-like pattern from the superficial to the deep zones. The results of the biochemical analyses are summarized in table 4.1. It was concluded that after 52 weeks the collagen content in neocartilage was not statistically significant different from normal cartilage (58 versus 60 per cent). After 52 weeks type $\|$ collagen accounted for 82 per cent of the total amount of collagen versus $>95$ per cent in normal articular cartilage. No further statistical increase in hexosamine concentration was observed at 52 weeks post surgery.

\subsection{Biomechanical properties}

Woo et al. (1987) studied the biomechanical properties of neocartilaginous tissues, formed out of rib perichondrial grafts which were placed in fullthickness articular defects in the rabbit's medial femoral condyle. A dynamic shear-testing apparatus was used to measure the viscoelastic properties of the neocartilage. The results were compared with those obtained from fresh rib perichondrium and with normal articular cartilage from the contralateral medial femoral condyles of 6-weeks old rabbit knees. The measured values for the complete shear modulus for both the regenerated cartilage and the rest of the cartilage of the same knee were within the range of shear modulus reported for normal rabbit articular cartilage. At 26 weeks the viscoelastic properties of the neocartilage approached those of normal articular cartilage. 


\subsection{Technical aspects}

The technical aspects of perichondrial grafting were studied by Coutts et a. (1984) by varying the graft location and the time of immobilization. The graft was secured to the bleeding bone bij drill holes and the joint was immobilized by a Kirschner wire connecting the tibia and femur. The medial femoral condyle, intercondylar groove and patella were compared as recipient sites: The grafts placed on the patella showed a significant failure rate by loosening. An immobilization period of 10 to 14 days proved to be necessary for an adequate fixation of the graft. In addition, the longer the joint was immobilized, the greater the amount of pannus around the graft.

In most studies the graft was sutured to the underlying bone or surrounding cartilage.

Ohlsen and Widenfalk (1983) were the first to use fibrin glue for the fixation of perichondrial grafts. The graft was placed on the bleeding cancellous bone. A close fixation was achieved between graft and underlying bone. With this method of graft fixation immobilization of the knee joint is mandatory for at least ten days or dislocation of the graft may take place (Widenfalk et al. 1986).

\subsection{Clinical application}

In 1959 Lester reported cartilage formation in the 7th rib of a boy of seventeen months, whose rib had been resected subperichondrially one year before. Skoog (1974) used perichondrium of the ear and used it in an otoplasty for protruding ears. In this way the congenital deformities of the ears were reconstructed with a free perichondrial graft.

Engkvist et al. (1975) transplanted costal perichondrium to reconstruct five clinical cases of arthritis of the smaller joints of the hand. Regeneration of new articular cartilage took place.

Skoog and Johansson (1975 and 1976) and Johansson and Engkvist (1981) described total reconstruction of articular cartilage in the destroyed joints of the fingers, using perichondrium from the sixth or seventh rib. An interposing silicone rubber spacer was used to prevent an overgrowth of cartilage and complete cartilaginous fusion of the joint after prolonged immobilization (Ohisen and de la Fuente, 1976). The microscopic section of the biopsy of the new joint showed hyaline cartilage, similar to normal articular cartilage and of usual thickness. A 20 year old carpenter developed arthrosis of the metacarpophalangeal joint, after a septic arthritis. Treatment by perichondrial grafting from the rib gave an excellent result. Four patients, from 50 to 65 years old, with degenerative arthrosis of the MCP-joint of the thumb improved by perichondrial arthroplasty, though some residual pain and restriction of movement remained.

Tajima et al. (1978) resected a small piece of bone in the ankylotic temporomandibular joint of six patients. The bony surface was covered with auto- 
genous rib perichondrium. After one year new joint surfaces were formed with encouraging clinical results.

Maruyama(1979) used perichondrial grafts in various clinical cases: For the repair of the external ear, the nose, the eyelid and an ankylotic temporomandibular joint. In some cases a cutaneous graft was used as recommended by Brent and Ott(1978).

Wilbrand and Engkvist (1979) and Engkvist and Johansson (1980) reported the results of perichondrial arthroplasty of the small joints of the hand and foot in 26 patients. The follow-up period varied from 3 to 42 months. The results of 13 patients were classified as excellent. In 3 cases range of motion and power improved, though some pain remained. Ten cases did not improve. Failures were considered to be due to improper selection. They recommended another type of operation when pain is present together with pronounced rigidity.

In the clinical studies of Pastacaldi and Engkvist (1979), Sully et al. (1980) and Jackson et al. (1981) perichondrial arthroplasty of the wrist and hand were described in rheumatoid arthritis. Relief of pain was obtained, though the range of motion varied. At the time of removal of the spacer, smooth, glistening joint surfaces were seen with a mottled yellowish colour. In more than half of the cases biopsies showed a layer of mixed fibrous tissue with cartilage islands. These histological findings are not in agreement with those found in the specimens obtained by Skoog and Johansson(1976) after post-traumatic metarcarpophalangeal joint reconstruction, in which case mature cartilage was demonstrated. The age of the patient, the underlying disease and the state of the recipient bed may be the main reason for this.

In a case study Hvid and Andersen(1981) reported perichondrial arthroplasty of the knee. A 55 year old lady with a traumatic cartilage lesion of the patella was treated succesfully with autografting of rib perichondrium. The graft was secured by dexon sutured through boreholes made in the patella. Arthroscopy 4 years after operation showed the medial facet covered with tissue resembling cartilage.

Seradge et al. (1984) tried to define indication and contraindication for perichondrial arthroplasty of MP and IP joints of the hand. In joints healed after pyarthrosis, systemic diseases with joint involvement, concomitant tendon reconstruction and in patients aged over 40 years the results were unsatisfactory.

Engkvist and Johansson(1980) performed perichondrial arthroplasty in 26 patients with painfull and/or rigid small joints of hand and foot. The mean age in the 'failure'group appeared to be less than in the 'excellent'group. So in this group the patient's age did not influence the result.

\subsection{Summary}

-Perichondrium taken from a rib and transplanted to a cartilage defect of the 
knee forms histologically, biomechanically and biochemically normal hyaline cartilage.

- Grafting of costal perichondrium gives superior results compared with perichondrium taken from the ear.

-Perichondrium keeps its chondrogenic capacity in adulthood.

-Two clinical reports are contradictory: it is not clear whether the age of the patient influences the result of perichondrial grafting.

-The influence of the graft orientation on the formation of cartilage remains a point of discussion. Good results are always achieved when the chondral side is facing the joint cavity.

-There is no agreement whether perichondrial grafts placed in cartilage defects of the rabbit's knees do or do not deteriorate after a longer period of time. Most clinical studies report good results after more than one year. The overall impression is, that cartilage formed out of perichondrium keeps its qualities also after one year follow-up.

- The recipient bed of the perichondrial may play a role in the formation of cartilage. In comparative studies it was concluded that the presence of a blood clot stimulates the formation of cartilage. Therefore it was recommended that the subchondral bone be removed and the perichondrial graft placed on the cancellous bone.

\subsection{Conclusions and considerations}

Animal experiments and clinical studies justify the use of perichondrium for repair of articular cartilage of destroyed joints. Cartilage damage is mostly limited to the non-osseous structure of the joint, leaving the subchondral bone intact. Graft fixation in a larger joint like the knee, should be performed with materials that do not damage or inflict the normal healthy cartilage. Moreover the material must be biodegradable and should not interfere with neochondrogenesis. Last but not least: with the ideal fixation device a secure and safe adhesion must be achieved between graft and recipient site. Fibrin glue develops minimal useful bonding but seems superior to cyanoacrylates and polymethylmethacrylate in terms of biological wound healing, biodegradability and non-toxicity (Weber and Chapman 1983). 


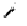




\section{Fibrin glue}

\section{1 introduction}

Clotting and wound healing are two phenomena closely linked together. Physiologically the process of wound closure starts when bleeding ceases. In places where injured blood vessels lie open, haemostatic clots are formed. They consist of platelets, red blood cells, and fibrinogen becoming more and more stable. Further steps in this process are fibrin cross-linking due to the action of factor XIII, and clot reaction where plasma is squeezed out. As various cells begin to proliferate into the retracted blood clot, wound healing sets in.

Young and Medawar (1940) were the first to try biological tissue synthesis with fibrinogen by fixing the cut sciatic nerve in rabbits. Because of poor strength and stability the results were disappointing until Matras et al.(1972) employed a special cryoprecipitate of highly concentrated fibrinogen with an increased factor XIII content. Additional problems such as the inhibition of fibrinolysis and the early onset of fibrin degradation, were solved by the introduction of aprotinin.

\subsection{Composition and mode of action of fibrin glue}

Tissucol (Immuno, Vienna, Austria) is a highly concentrated fibrinogen cryoprecipitate made out of human serum. It is a two component fibrin glue. The first component contains mainly fibrinogen, together with plasmaproteins as fibronectin (cold insoluble globulin, CIG) albumin and factor XIII. The second component contains thrombin and calciumchloride. Aprotinin is added as a fibrinolytic inhibitor. When these two components are mixed the following reaction takes place: 
Thrombin

Calciumchloride

Fibrinogen $_{>}$Fibrin(monomer $_{T}>$ Fibrin(polymer) $_{T}>$ Fibrindegradat.

Factor XIII $\rightarrow$ Factor XIIla $\rightarrow$

Aprotinin

Coagulation

Cross linking

Fibrinolysis

Thrombin transforms fibrinogen into fibrin monomers, which aggregate and form a gell. At the same time thrombin activates factor XIII to factor XIIIa in the presence of calcium ions. Factor XIIla crosslinks the aggregated fibrin monomers to a high molecular weight polymer; through this reaction the rigidity of the sealing and the resistance to fibrinolytic degradation are increased. The stability of the clot is further established. Factor XIIIa crosslinks the fibronectin, which is present in Tissucol, and probably crosslinks fibrin and fibronectin with the collagen of the tissue to which the sealant was applied. In the course of the wound healing process, plasminogen activators derived from the surrounding tissue activate the small amount of plasminogen, present in Tissucol to plasmin. By this reaction the crosslinked fibrin is eventually lysed into soluble fibrin degradation products. This process is retarded depending on the aprotinin concentration chosen. The purpose of the added aprotinin is to prevent the early dissolution of the glue in the body (Redl et al. 1982).

The clotting time depends on the thrombin concentration: with a concentration of $4 \mathrm{I.U} / \mathrm{ml}$ and a temperature of $37^{\circ} \mathrm{C}$ it is one minute; with a concentration of $500 \mathrm{I} . \mathrm{U} / \mathrm{ml}$ it is less than 10 seconds (Figure 5.1). The higher con-

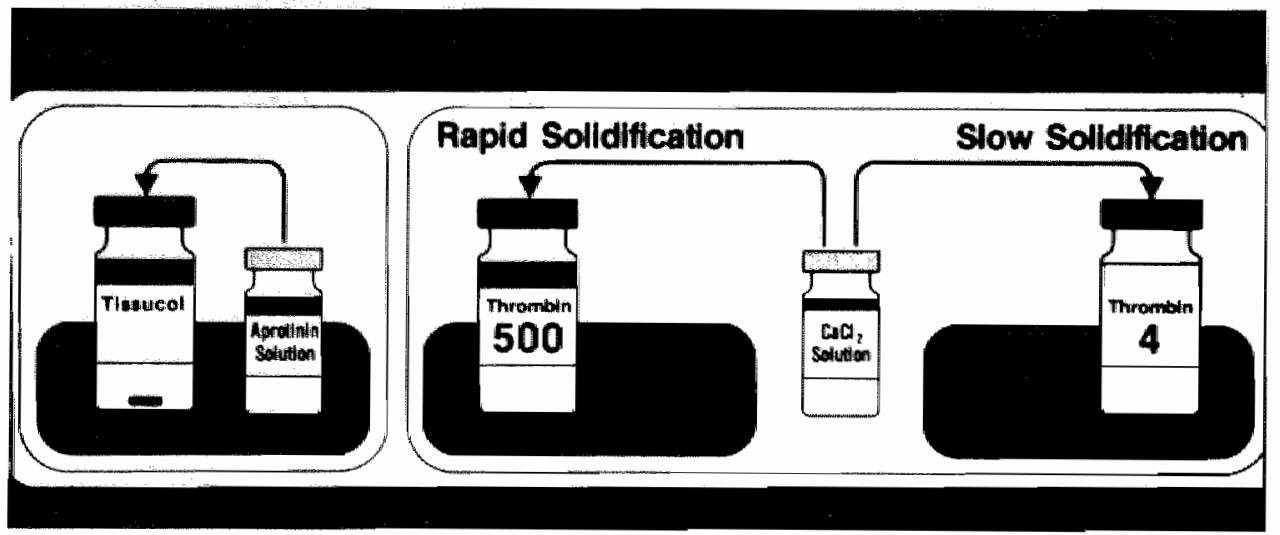

Figure 5.1.

Schematic drawing of the mixing of the fibrin components. 
centration of thrombin is used to stop bleeding, the lower concentration is more applicable in cases of tissue adhesion when more time is needed to adapt the two tissues.

For the manufacturing of $1 \mathrm{ml}$ Tissucol solution the following active components are needed:

-The sealer Protein Concentrate of which fibrinogen plasma fibronectin (CIG) Factor XIII

-Aprotinin solution

-Thrombin 4, lyophilized (bovin) after solution $1 \mathrm{ml}$ contains

Or:

-Thrombin 500, lyophilized (bovin) after solution $1 \mathrm{ml}$ contains -Calcium chloride solution

$$
\begin{aligned}
& 75-115 \mathrm{mg} \\
& 70-10 \mathrm{mg} \\
& 2-9 \mathrm{mg} \\
& 10-50 \mathrm{E} \\
& 3000 \mathrm{KIE} / \mathrm{m} 1
\end{aligned}
$$

4 I.U.

500 I.U.

$40 \mathrm{mmol} \mathrm{CaCl}_{2} / \mathrm{ml}$

Freeze-dried Tissucol is reconstituted with an aprotinin solution by stirring at $37^{\circ} \mathrm{C}$. It is also possible to place the vial in a thermostatically controlled waterbath in which it is swirled with a circular motion. Heating beyond $40^{\circ} \mathrm{C}$ should be avoided, as heat-sensitive protein can be denatured.

In order to facilitate a quick reconstitution of the freeze-dried constituents, the Fibrinotherm, a combined warming and stirring device, has been develloped.

Wound healing starts when fibroblasts from the surrounding tissue begin to invade the blood clot or fibrin sealant. The fibrin structure serves as a matrix for ingrowing fibroblasts. Their adhesion to fibrin is due to fibronectin, a surface protein of fibroblasts, which is crosslinked with fibrin by factor XIIla. Collagen synthesis from the fibroblasts marks the beginning of connective tissue formation.

Dinges et al. (1986) compared the ingrowth of fibroblast in cavities of spongiosa with and without fibrin sealant. The fibroblast-stimulating effect of the sealant was significant compared with the control group (16 per cent fibroblast per volume granulation tissue in the control group, 22 per cent in the fibrin sealant group).

To test the osteo-inductive property of fibrin glue, Zilch and Wolff (1987) made three holes of $4 \mathrm{~mm}$ diameter and $2 \mathrm{~mm}$ depth into the diaphysis of both femora of 12 adult dogs. The defects were either filled with pure fibrin glue or with glue containing aprotinin (a supposed inhibitor of osteogenesis): 3 holes remained vacant. No statistically significant difference was 
seen between the three groups regarding the quantitity of new bone. It was concluded that fibrin glue has no osteo-inductive property. In conclusion it can be stated that there is still no certainty about the osteo-inductive capacity of fibrin glue, but that it imitates the normal function of physiological fibrin (Schlag and Redl 1988).

\subsection{Bonding capacity}

In both tensile and shear tests the strength of cartilage to cartilage and cartilage to bone adhesion was tested in one year old cows, using fibrinogen adhesive (Claes et al. 1981). After 30 minutes a tensile strength of $7.1 \pm$ $2.8 \mathrm{~N} / \mathrm{cm}^{2}(n=21)$ and a shear strength of $4.6 \pm 1.6 \mathrm{~N} / \mathrm{cm} 2(n=15)$ was measured between cartilage and cartilage. The shear strenght between bone and cartilage was $4.2 \pm 2.4 \mathrm{~N} / \mathrm{cm} 2$.

A chondral flake fragment of the rabbit knee was fixed with a mixture of fibrinogen, thrombin and factor XllI concentrate (Braun et al. 1982). The influence of immobilization and fibrin application was assessed after different periods of time. The number of succesfully glued fractures was highest in the group of 14 days postoperative fixation followed by 4 weeks of free movement.

Keller et al. (1985) fixed standardized osteochondral fractures in the femoral condyle in 19 adult mongrel dogs with either fibrin sealant or Kirschner wires. Although the initial strength of the fibrin glue was low, the tendency of displacement in this group was less than in the K-wire group. After 4 days the maximum strength of the fibrin sealed fragment had increased approximately sevenfold $\left(5.1 \pm 0.8 \mathrm{~N} / \mathrm{cm}^{2}\right)$.

In a review article about "Adhesives in Orthopaedic Surgery" Weber and Chapman(1983) described and tested the in vitro bonding strenghts of bone-bonding agents like cyanoacrylates, polymethylmethacrylates and fibrin adhesives in cortical bone. Fibrin adhesives developed minimally useful bonding (Mean $0.0006 \mathrm{MPa}$ ) and were inferior in adhesion to both long- and short-chain cyanoacrylates (Mean 0.127 MPa). PMMA was the best bonding agent tested (Mean 1.01 MPa). For reference: The mean strength of intact bone is $5.77 \mathrm{MPa}$ (SD 2.19). Therefore fibrin adhesives have insufficient adhesion for osteosynthesis unless the fracture configuration has considerable inherent stability.

\subsection{The use of fibrin glue in the fixation of (osteo)chondral fragments}

Pure articular cartilage fragments were transplanted into the knee joint of sheep, using fibrin sealant to fix the transplant to the recipient site. Light and electron microscopic studies revealed viable transplants up to 7 months and a stable bony union with the host through endochondral as well as subchondral bone formation (Passl et al. 1976). In 10 animals the chondral transplant was fixed with cyanoacrylate. In this group the results of only 
2 grafts were macroscopically and light microscopically satisfactory.

Braun et al.(1979) compared the results of reimplantation and fixation with fibrin glue of osteochondral fragments in the knee joint of rabbits between three groups: a group without immobilization, a group with temporary immobilization with an external fixation for two weeks and a group with 6 weeks of immobilization. He concluded that immobilization of the joint for two weeks gives the best results.

Experimentally produced osteochondral fractures of the radial head and femoral condyle in dogs were fixed with a fibrin sealant, containing fibrinogen, thrombin and a fibrinolytic inhibitor. Contralateral control fractures were fixed with $5-\mathrm{mm}$ Kirschner wires. No external immobilization was utilized. All fractures consolidated uneventfully after 8 weeks. Osseous repair seemed to be stimulated by the sealant and to occur faster than in the fractures fixed with pins (Meyers and Herron 1984).

Autologous, homologous and heterologous (canine) chondral transplants were placed into defects of tibia plateau and medial femoral condyle of the knee joints of sheep and fixed with the fibrinogen adhesive system or Histoacryl (R), a cyanoacrylate (Plenk and Passl 1980). The transplants fixed with fibrin glue fused with the subchondral bone after 4 weeks. At the same time new mineralisation of cartilage and bone took place as can be concluded from tetracycline-labelling upon the trabeculae and the base of the transplant. 7 Months after transplantation a total fusion between transplant and surrounding cartilage had taken place. After this period of time the borderline to the subchondral bone showed a marked elevation beyond most of the grafts. In the group of transplants fixed with Histoacryl (R) all but one were lost. A layer of granulation tissue with multinucleated giant cells, surrounding remnants of Histoacryl (R), separated the graft from the subchondral bone which showed resorption. The same sort of granulation tissue was found in the empty beds of the lost transplants. After heterologous transplantation an inflammation of the operated knee was observed and the grafts were covered with pannus formation. Some of them were fused with the subchondral bone.

The succesful clinical application of fibrin adhesive is demonstrated by the same authors in 4 cases after replantation of traumatically cut-off, large cartilage fragments: All patients became free of symptoms with a full range of motion of the operated joint.

Zilch (1980) carried out an experiment on revascularization of glued osteochondral fragments: a chiseled part of the medial femoral condyle of the knee joint of the rabbit was fixed on the right side with an acryl adhesive and on the left side with a fibrinogen adhesive system (FAS), consisting of highly concentrated fibrinogen, thrombin and factor XIII. The animals were killed after $3,6,10$ and 28 days. The FAS was changed into granulation tissue rich in vessels and therefore a quick revascularization of the fragments was found after three days. On the other hand the acryl adhesive is a foreign body and prevents ingrowth of capillaries. Immobilization proved to 
be necessary to prevent the fragment from gliding off.

Chondrocytes, isolated from the epiphyses of human fetus, were stored in liquid nitrogen, thawed, resuspended in thrombin solution and applied together with fibrin adhesive to a cartilaginous defect of a rabbit's knee. Regeneration and formation of new cartilage occurred (Helbing and Burri 1982).

Passi et al.(1979) transplanted autologous cartilage grafts and reimplantated loose fragments of cartilage into the knee and ankle. The graft was fixed with fibrin glue. Excellent clinical results were reported.

Clinical use of fibrin glue for adhesion of chondrall and osteochondral fractures of the femoral head, the knee and talus has been reported to give good results (Bohler and Gaudernak 1984). External fixation of the joint was given when larger pieces of cartilage were dislocated (18 out of 39 cases). Paar et al.(1984) treated 44 chondral and osteochondral fractures of the knee and the talus. 4 Patients with pure chondral separations had to be reoperated because of dislocation of the fragment after initial fixation with fibrin glue. In 6 patients with old cartilage defects in the weight bearing area of the medial,femoral condyle autologous cartilage was transplanted and fixed with fibrin glue. In 5 cases a reoperation was necessary because of redislocation of the chondral fragment. The best results were achieved in fresh traumatic cartilage defects.

Glückert and Weselch(1982) replaced 7 osteochondral fragments of the knee with fibrin glue and immobilized the knee for 6 weeks. Arthroscopic control in 6 cases after 18-42 months showed weakened and softened areas of cartilage of the replaced fragments in 4 patients. In 2 patients the surface of the replaced chondral fragments was smooth, solid and of the same colour as the rest of the cartilage. When refixation of the chondral fragment was performed, within a limited period after separation, good results were achieved.

Rupp and Stemberger (1978) used the technique of the autologous osteochondral exchange in the knee joint for the repair of a destroyed cartilage surface. Fixation was carried out with fibrin glue followed by two weeks of immobilization and three months of non-weight bearing. All patients were reported to be without symptoms after eight months.

Bernett et al.(1982) reported the results of gluing chondral and osteochondral tragments of the knee, the ankle and elbow in 26 patients. The clinical results are encouraging. In 3 patients arthroscopy was performed (follow-up 3-12 months): The refixated fragment seemed completely reincorporated and resembled the surrounding cartilage.

Zilch and Friedebold (1982) treated 20 patients with dissecates caused by osteochondritis dissecans and 12 traumatic osteochondral fractures by adhesion with fibrin glue. He reported favourable early results but considered immobilization of the joint mandatory for three weeks. Fixation of chondral fragments should only be attempted when fragments extend to the bone. In these cases the authors consider opening of the subchondral bone 
necessary:

in summary it may be concluded that fixation of loose cartilage fragments with fibrin glue gives good results in clinical practice. A temporary immobilization of the joint for 2 weeks seems to be necessary, otherwise there is a risk of loosening of the fragment. This conclusion is in agreement with the animal experiments of Widenfalk et al.(1986) who fixed a perichondrial graft in a cartilage defect of the rabbit's knee with different periods of external immobilization: only after 10 days of joint immobilization $100 \%$ of the grafts stayed in their original position.

\subsection{Biocompatibility and risk of contamination}

Clinical application of fibrin adhesive for fixation of perichondrium to the underlying bone depends, apart from its bonding strength, on its toxicity, local tissue reaction, and biodegradability. Preparations made out of human plasma carry a possible risk of transferring viral infections like the Auantigen, which is responsible for hepatitis-B, and HIV, responsible for the aquired immune deficiency system (AIDS). Allergic and toxic reactions of fibrin glue have not been reported. However, the use of concentrated blood products carries a slight risk of hepatitis (Giebel and Rimpler 1981).

In a prospective study Scheele et al.(1981) compared two groups of 155 patients after general surgery. In the first group a fibrin adhesive system was used; the second group served as a control. The incidence of postoperative hepatitis B infection was comparable in both groups i.e. $2.9 \%$ and $3.7 \%$ respectively. So far no irrmunologic reactions have been reported in homologous systems. In heterologous systems immunologic reactions are possible which are humorally mediated. These reactions become effective when preceded by sensibilization or when the fibrin adhesive is retained in the body for more than 7 days (Braun 1975). In the series of rabbits with preoperative immunization against bovine fibrinogen-cryoprecipitate a full thickness autologous skin graft was completely discharged and the healing procedure of the defect was retarded.

Scheele and Pesch (1982) studied the morphological aspects of fibrin degradation in parenchymous organs and in the trachea of rabbits and dogs. In the kidney and in the liver cellular infiltration occurred after three days and after 15 days a strong, hypervascular seam was found without any remnants of fibrin glue. The time of total elimination did not only vary between different organs but also between the two animal species. In general the fibrin survived longer in the rabbit than in the dog. In the same animal, fibrin was eliminated faster in parenchymous organs than in the trachea. Although human fibrinogen was used, no glue-induced tissue damage was seen. Giebel and Rimpler(1981) found biological resorption of the adhesive within a few days.

Staindl and Galvan (1982) studied the resorption time of fibrin glue in 9 patients with a basalioma or spinalioma in the face. The tumor was resected 
and the defect was covered with a regional skin flap or full-thickness skin graft. The fibrinogen was labeled with 1251 . The absorption rate was checked postoperatively by daily isotope determination. The investigation was carried out in two groups: whereas the fibrin adhesive was used only in group a), a factor XIII was added in group b) for fibrin stabilization. Various fibrinolytic curves show a rapid degradation of the fibrin glue in the first ten days. This process is delayed by adding factor XIII-concentrate.

\subsection{Summary}

-So far no toxic or allergic reactions have been reported on the fibrin adhesive system.

-The risk of transferring hepatitis-B or HIV seems, with the present precautions, minimal or absent.

-Absorption and degradation of fibrinogen takes place within 14 days and can be delayed by adding factor XIII-concentrate.

-When a chondral graft is transplanted and fixed to the subchondral bone the base of the graft is mineralised.

-The initial bonding capacity of fibrin glue is low. In the use of adhesion of a chondral or osteochondral fragment, or the fixation of a perichondrial graft in a joint, immobilization of the joint is necessary for 14 days. 


\section{Perichondrial arthroplasty of the rabbit knee}

-A comparison with spontaneous healing of articular cartilage defects-

\section{Based on:}

Repair of articular defects by perichondrial grafts: experiments in the rabbit. Homminga GN, van der Linden AJ, Terwindt-Rouwenhorst EAW and Drukker J. Acta Orthop Scand 1989;60:324-30.

\subsection{Introduction}

In order to test a model for the clinical application of perichondrial arthroplasty, three conditions have to be fulfilled:

1. Costal perichondrium should be able to develop into articular cartilage when placed in a cartilage defect with intact or absent subchondral bone. 2. Fibrin glue, combined with two weeks immobilization of the joint, must be able to give sufficient adhesion of the graft to achieve adequate fixation.

3. Perichondrial arthroplasty must give better results than the spontaneous healing process of articular cartilage defects.

In an experimental study with rabbits these prerogatives were tested (Figure 6.1).
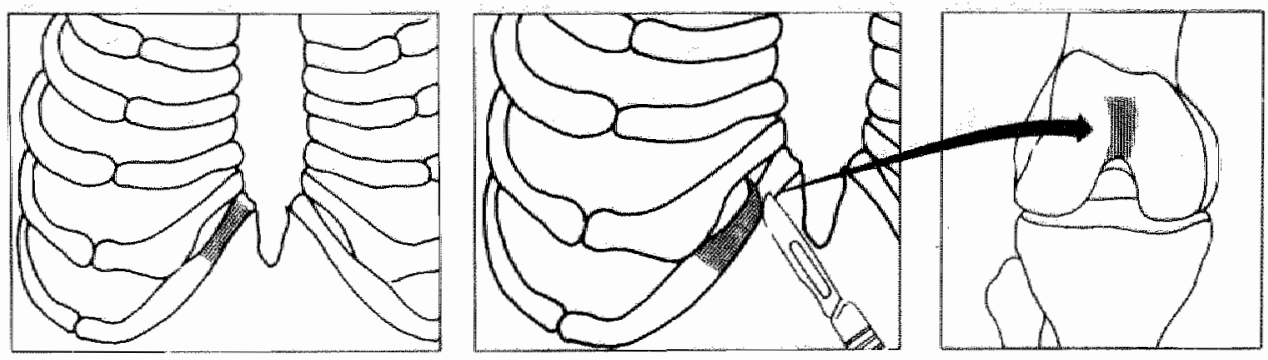

Figure 6.1.

Schematic drawing of the animal experiments. A piece of perichondrium is dissected from the cartilaginous part of the rib and placed in a cartilage defect of the knee. 


\subsection{Materials and methods}

Fourty rabbits, cross-bred Flemish giants, weighing $3.5-5 \mathrm{~kg}$ were used. All but one were male. Four groups were formed with a follow-up period of 4,8 , 16 and 52 weeks. For the first three groups young rabbits were used, sixteen to twenty weeks old, with the epiphyses still open. The last group consisted of adult rabbits. Anaesthesia was given by intravenous injection of ketamine hydrochloride $(100 \mathrm{mg} / \mathrm{kg})$ and diazepam $(8 \mathrm{mg} / \mathrm{kg})$. Arthrotomy of both knees was performed by a medial parapatellar incision and the patella was dislocated laterally. With a surgical blade a cartilage defect measuring $10 \times 5 \mathrm{~mm}$ was created in the intercondylar groove down to the subchondral bone. The subchondral bone plate was scraped until pointbleeding started, but not perforated. Subsequently an oblique incision as made over the lower part of the chest wall, exposing the lower ribs. A strip of perichondrium was dissected from the cartilaginous part of one of the lower ribs through its natural cleavage plane. The graft was kept in a normal salline solution.

Tissucol (R), a highly concentrated human fibrin glue, was prepared by mixing fibrinogen $(70-110 \mathrm{mg} / \mathrm{ml})$ and aprotinin $(3000 \mathrm{KIE} / \mathrm{ml})$ and thrombin (4 I.U) with calciumchloride $(40 \mathrm{mmol} / \mathrm{l})$. These mixtures were placed in the Fibrotherm a combined heating and stirring device, and heated to $37^{\circ} \mathrm{C}$.

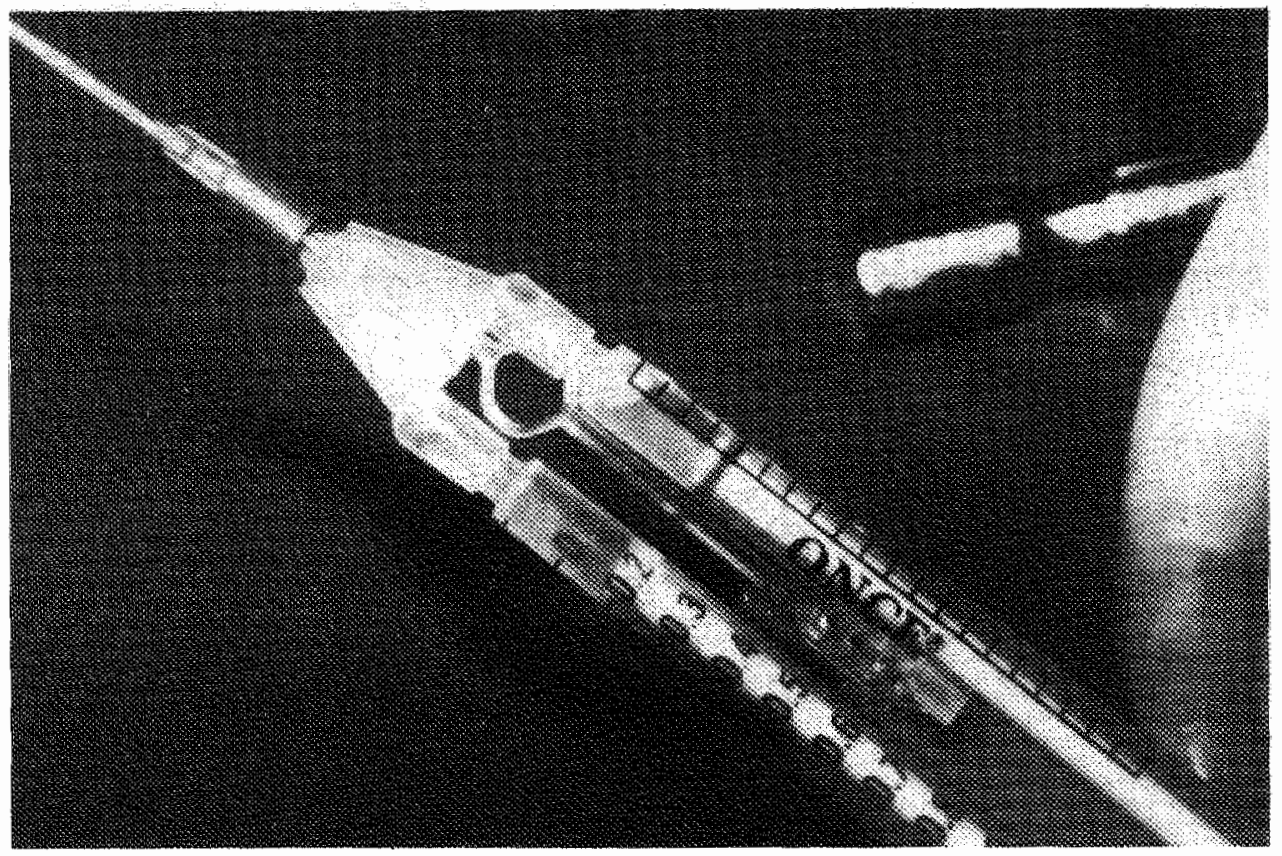

Figure 6.2.

A duploject system is used for simultaneously mixing of the fibrin components. 
Additionally the fibrinogen vial was placed into the opening of the magnetic stirring. Each Tissucol vial contains a stirring bar which is made to rotate by a magnet, revolving with the appliance. By stirring the contents for about 10 minutes optimal reconstitution is ensured.

The setting rate of the sealant depends on the concentration of the thrombin solution. A thrombin concentration of $4 \mathrm{lU} / \mathrm{ml}$ is used i.e. the slow modification rate, which provides sufficient time to place the graft into the defect. For the application of the components the Duploject system is used (Figure 6.2).

This device was especially designed to allow single-handed operation with an intimate mixing of the components which ultimately ensures strength of the Tissucol sealant. The Duploject system consists of a clip for two identical disposable syringes and is designed for the simultaneous operation of two plungers so that equal volumes of the two components are passed through a common joining piece. The two components are thouroughly mixed in the application needle which is attached to the joining piece. The size of the perichondrial graft was adjusted to that of the cartilage defect. The fibrin glue was applied and the graft was placed in the defect with the chondral side facing the knee joint. It was firmly pressed to the subchondral bone with a wet gause during one minute (Figure 6.3).

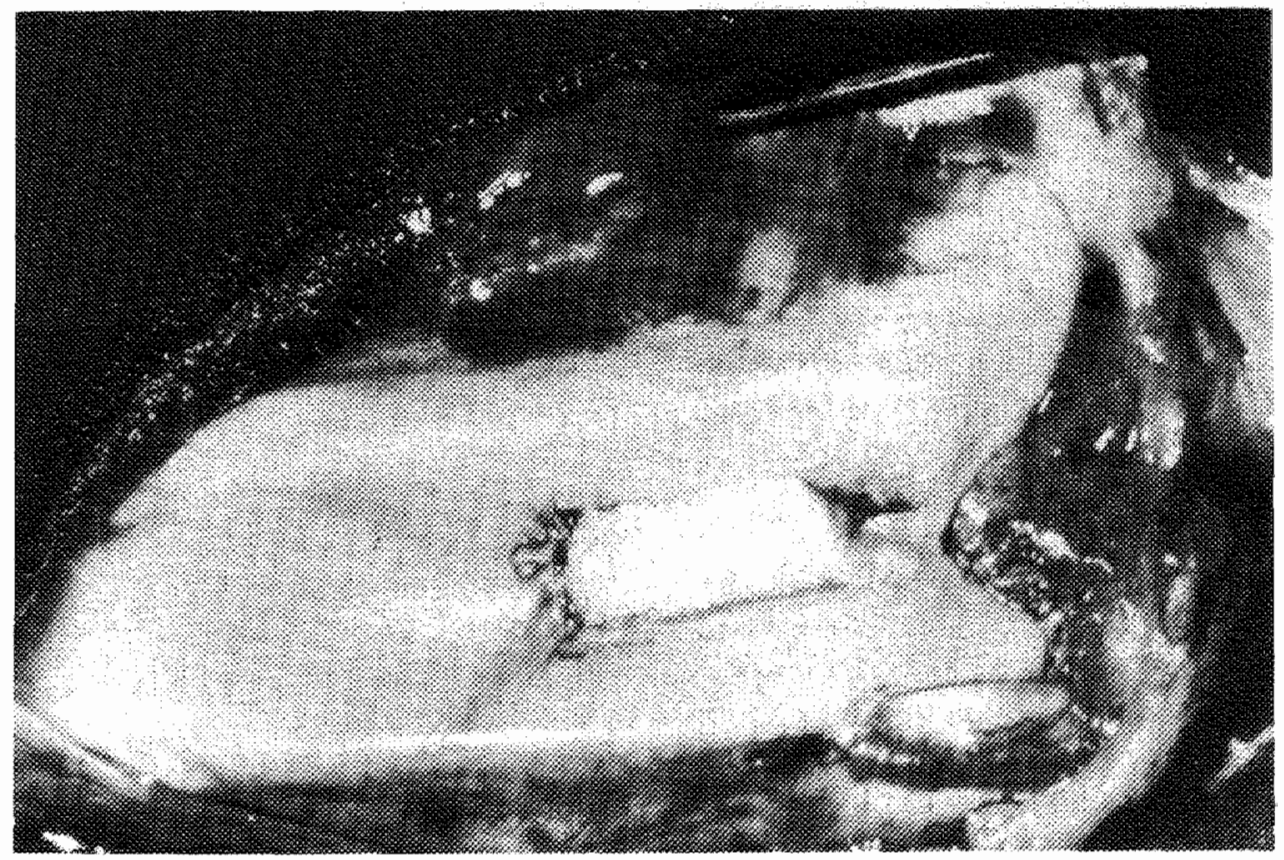

Figure 6.3.

The perichondrial graft is placed in the cartilage defect of the intercondylar groove, the chondral side facing the knee joint. 
The defect in the left knee was filled with fibrin glue but not grafted.

The right knee was immobilized by an external fixation device of K-wires through distal femur and proximal tibia connected by medial and lateral bars. Two weeks later the device was removed and the rabbits were left to move freely in their cage. The left knee was not immobilized.

The animals were killed after 1,2,4 and 12 months giving four groups of ten rabbits. The graft was examined macroscopically and compared with the appearance of the control defect. At gross inspection the following graft qualities were asessed:

Colour: intense white, white, yellow-white (hyaline).

Confluency: the level of the graft compared with the surrounding cartilage: depressed/level/elevated.

Shining aspect: dull or shining and reflecting.

Consistency: soft, semi-solid and solid (hyaline).

Smoothness: rough and irregular, or smooth (hyaline).

Two specimens were taken from the graft location, two from the medial femoral condyle of the sane knee and one from the non-grafted defect of the left knee. From every group one rabbit was selected for a total condylar specimen. The specimens were fixed in neutral formaline, embedded in paraffine, sectioned at $10 \mu \mathrm{m}$ and stained with haematoxylin-eosin, safranin 0 fast green and alcian blue-PAS (Burck 1981).

Micrascopic examination focused on the following items:

-Graft thickness, measured in the middle of the graft, cartilage or defect. -Cell orientation and tissue organisation.

-Formation of palisades.

-Number of cells per $\mathrm{mm}^{2}$ in the deep and in the superficial layer. Cells were counted over an area of $0.5 \times 0.05 \mathrm{~mm}$. Values are mean with standard deviation (S.D.).

Cytologic features and the ratio chondrocytes: fibrocytes.

-The presence of calcium in the the newly formed cartilage.

In the specimens stained with haematoxylin-eosin the number of cells and the organisation structure were studied. Cytologic features and matrix production in the different layers were judged in the safranin O stained specimens (Rosenberg 1971). Acid mucopolysaccharides production, indicating the formation of cartilaginous tissue, was assessed by alcian blue staining (Erronen 1978). The presence of a blue colour in the intercellular substance indicates matrix production by the chondrocytes.

With the calcium staining technique according to Eros the formation of calcium in the newly formed tissue was recorded and compared with that of the biopsy taken from the medial femoral condyle.

Biochemical analysis to determine the amount of collagen II, according to O'Driscoll et al.(1985) was done on two loose bodies found in the knee after 
4 weeks.

After one year tangential $X$-rays in caudo-cranial direction were taken of the intercondylar groove of the right and left knee in $30^{\circ}, 60^{\circ}$ en $90^{\circ}$ using 40 kV-13 mAs.

\subsection{Results}

Four of the 40 grafts had dislocated to form hyaline-like loose bodies in the knee. Microscopically a normal hyalin cartilage structure was seen with chondrocytes in a well staining matrix. The loose bodies contained $100 \%$ collagen II.

One rabbit developed a septic arthritis and in one rabbit the right leg was paralytic after operation. (This complication was probably caused by a misrouted K-wire of the external fixation device, perforating the sciatic nerve). In the one year group two animals died after six and seven months by an unidentified cause.

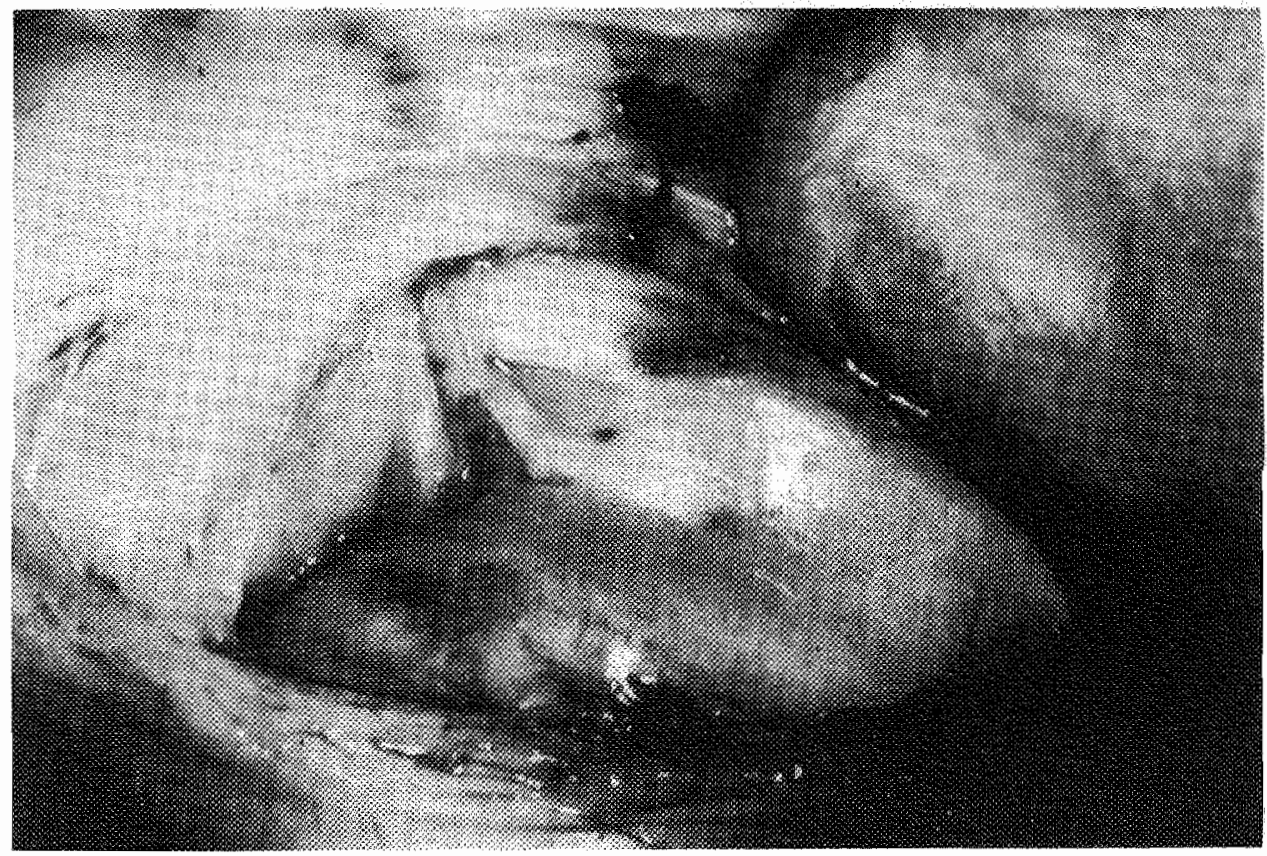

Figure 6.4

Perichondrial graft after 4 weeks: White, slightly elevated and easily imprintable. 


\section{One month $(n=7)$}

An elevated, white, dull, rough and soft tissue had developed at the graft site (Figure 6.4)(table II). Microscopically a thick layer, average $1210 \mu \mathrm{m}$ (SD 360), was seen (Figure 6.5),

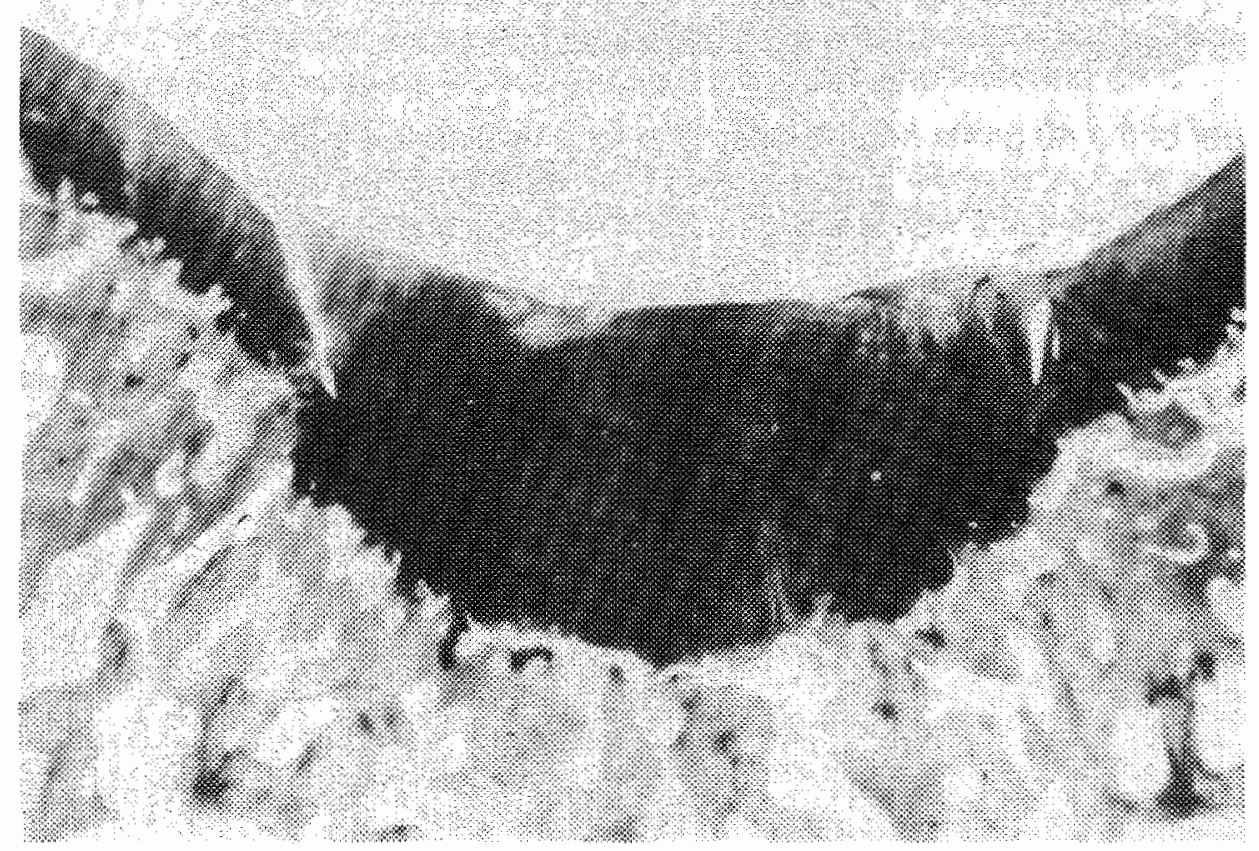

Figure 6.5.

Low-power photomicrograph after 4 weeks: $A$ thick layer densely filled with fibrocytes and chondrocytes in an intensely staining matrix. Safranin O fast green $\times 36$.

with mainly fibrocyte-like cells (Figure 6.6). At the base, near the subchondral bone, some oval -shaped cells were present. The estimated percentage of chondrocytes was 32 (SD 27). No specific organisation such as in hyaline cartilage could be observed and palisades were absent. In the safranin 0-fast green and alcian blue-PAS an intense staining of the matrix was present in all the layers. The transition between the graft and the underlying bone was fluent, without a space separating the two tissues. Between graft and surrounding cartilage occasionally a cleft could be observed and in most cases a clear border was visible. With the calcium staining no increased calcium concentration could be established.

The specimens taken from the medial femoral condyle showed normal hyaline cartilage with an average thickness of $340 \mu \mathrm{m}$ (SD 60).

In the non-treated control defect of the left knee a very thin veil of white, non-reflecting. soft tissue was found at the bottom. Histologically spindle like cells were seen without any sign of matrix production. 


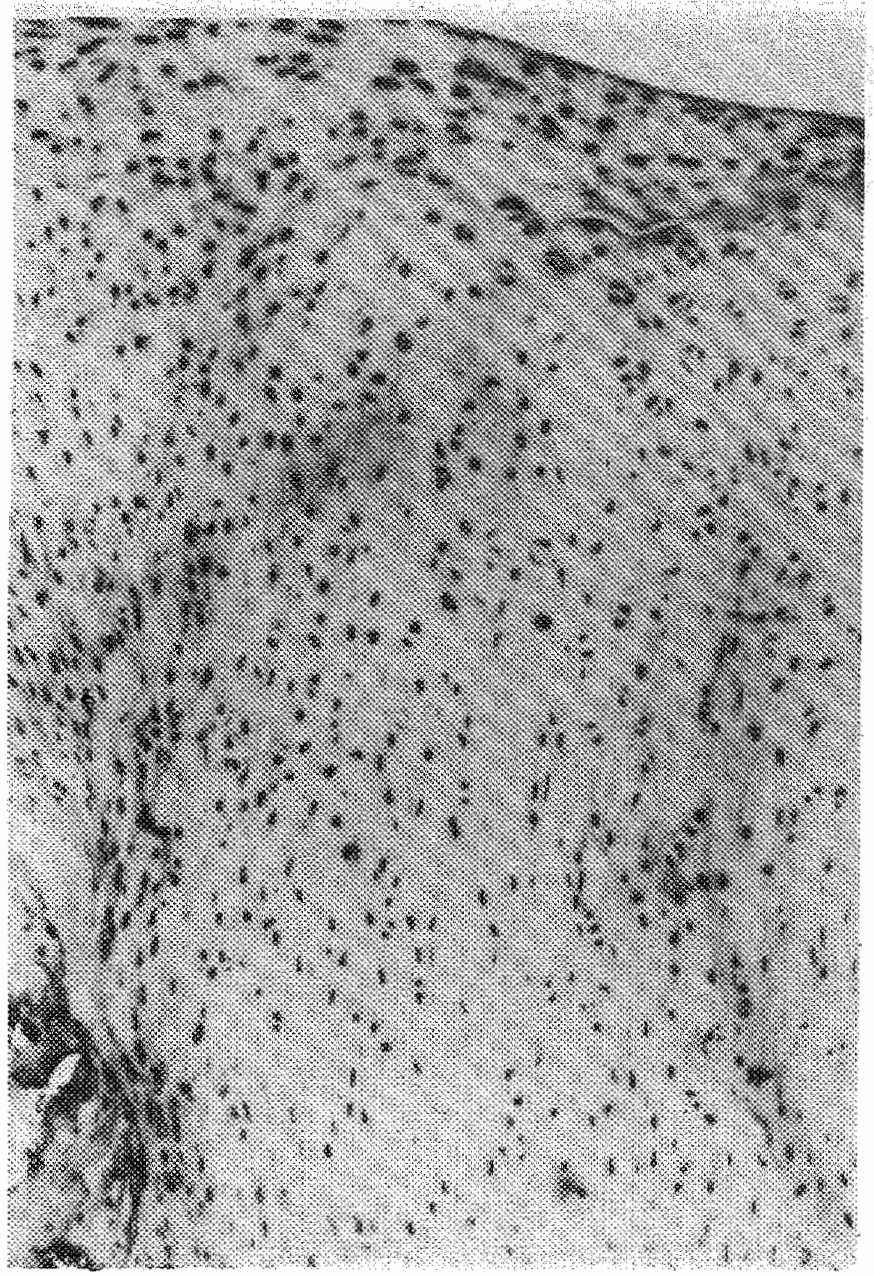

Figure 6.6.

Photomicrograph of the graft after 4 weeks: Note the spindle-like cells resembling fibrocytes. HEX230.

\section{Iwa months $(n=9)$}

Upon gross examination the grafted area was at the same level as the surrounding cartilage looking whitish, shining and smooth and semi-solid at touch (Figure 6.7). Histologically the average graft thickness had decreased to $710 \mathrm{\mu m}$ (SD 440) (Figure 6.8). Most of the cells (83\%) resembled chondrocytes, large in size (Figure 6.9). Matrix staining was moderate and restricted to the basal and intermediate zone. Palisade formation had started in the basal layer. The calcium staining seemed not to be increased. The average thickness of the cartilage of the medial femoral condyle of the right knee was $380 \mu \mathrm{m}$ (SD 180). The control defect of the left knee re- 


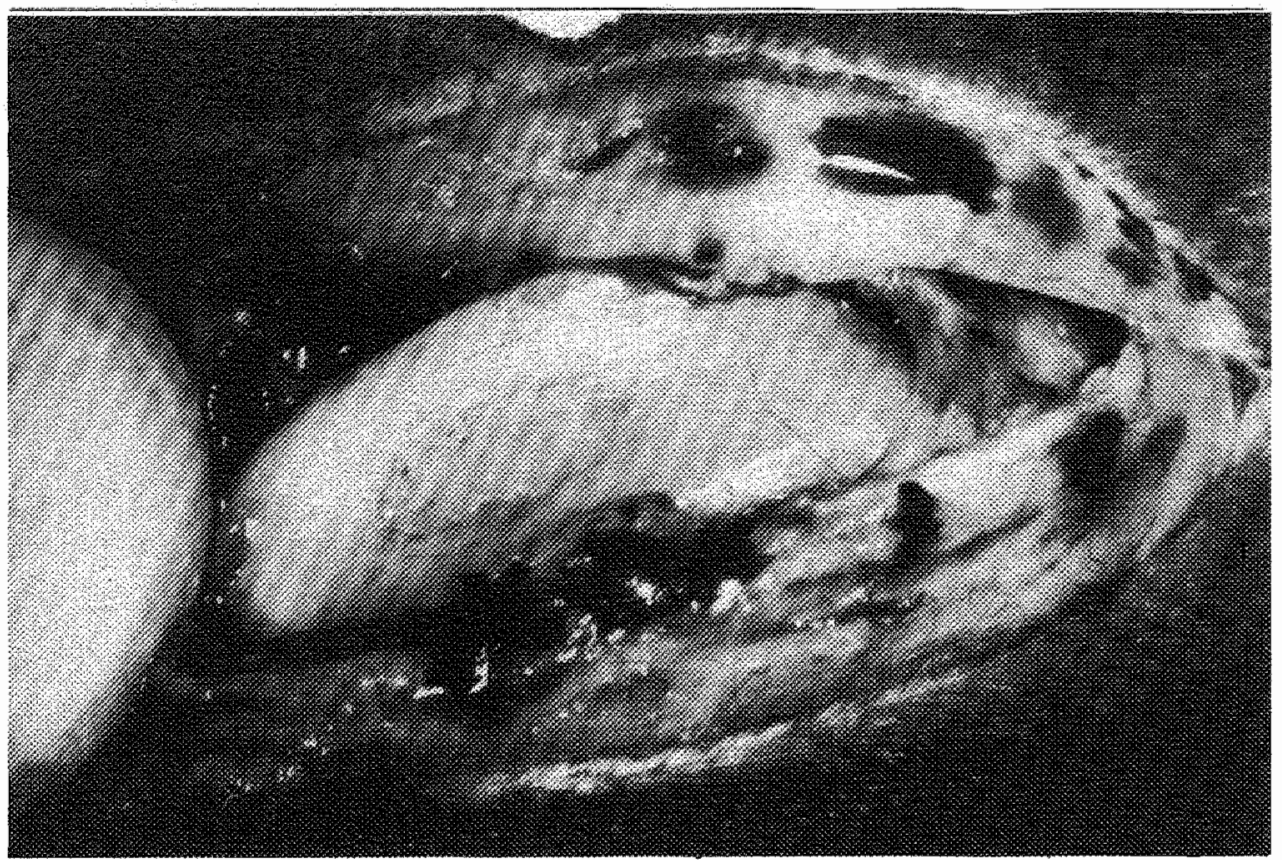

Figure 6.7.

Perichondrial graft after 8 weeks.

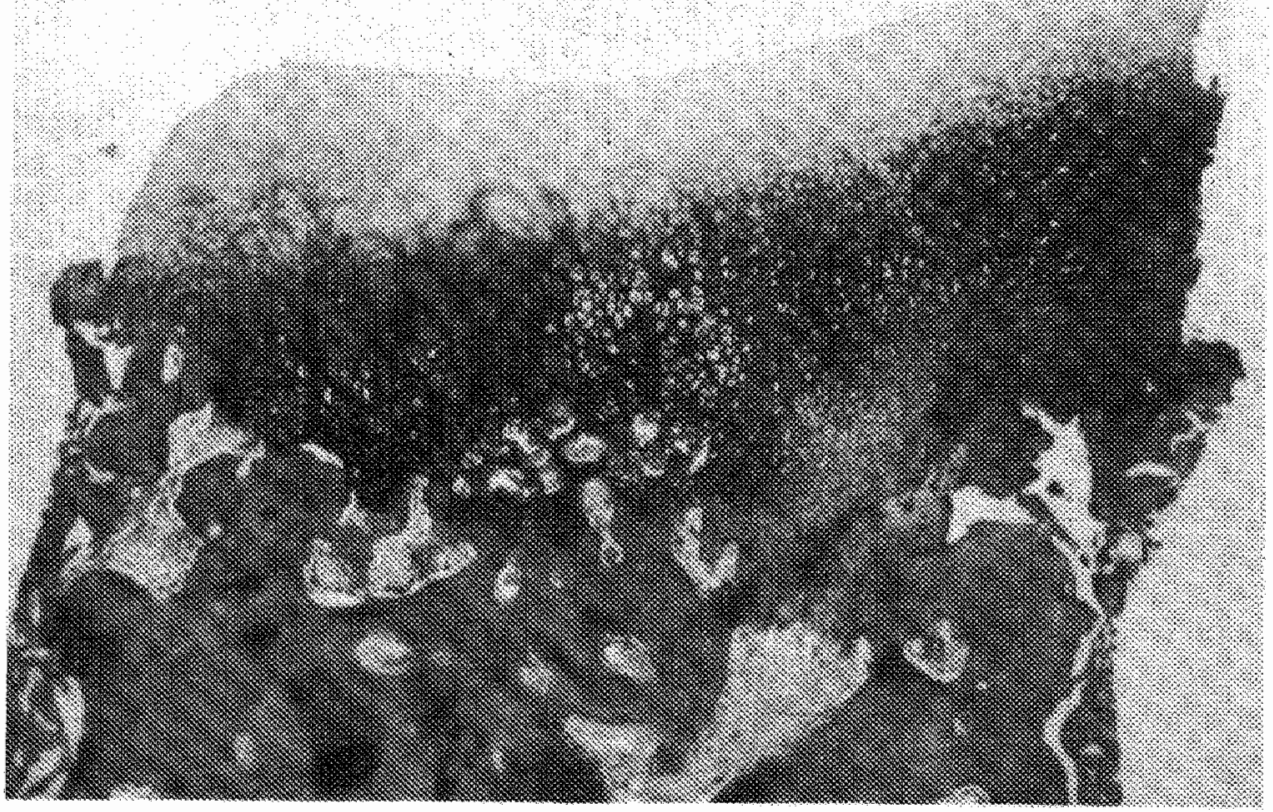

Figure 6.8 .

Low-power photomicrograph of the perichondrial graft after 8 weeks: Densely packed chondracytes in a slightly staining matrix. Alcian Blue PAS $\times 36$. 
mained clearly visible owing to its depressed level and irregular, dull surface. In 7 of the control specimens the shape of the cells had evolved to oval; the cells lying in a slightly staining matrix. In the remaining 3 only spindle-like cells, resembling fibrocytes, were arranged in parallel in a non staining matrix.

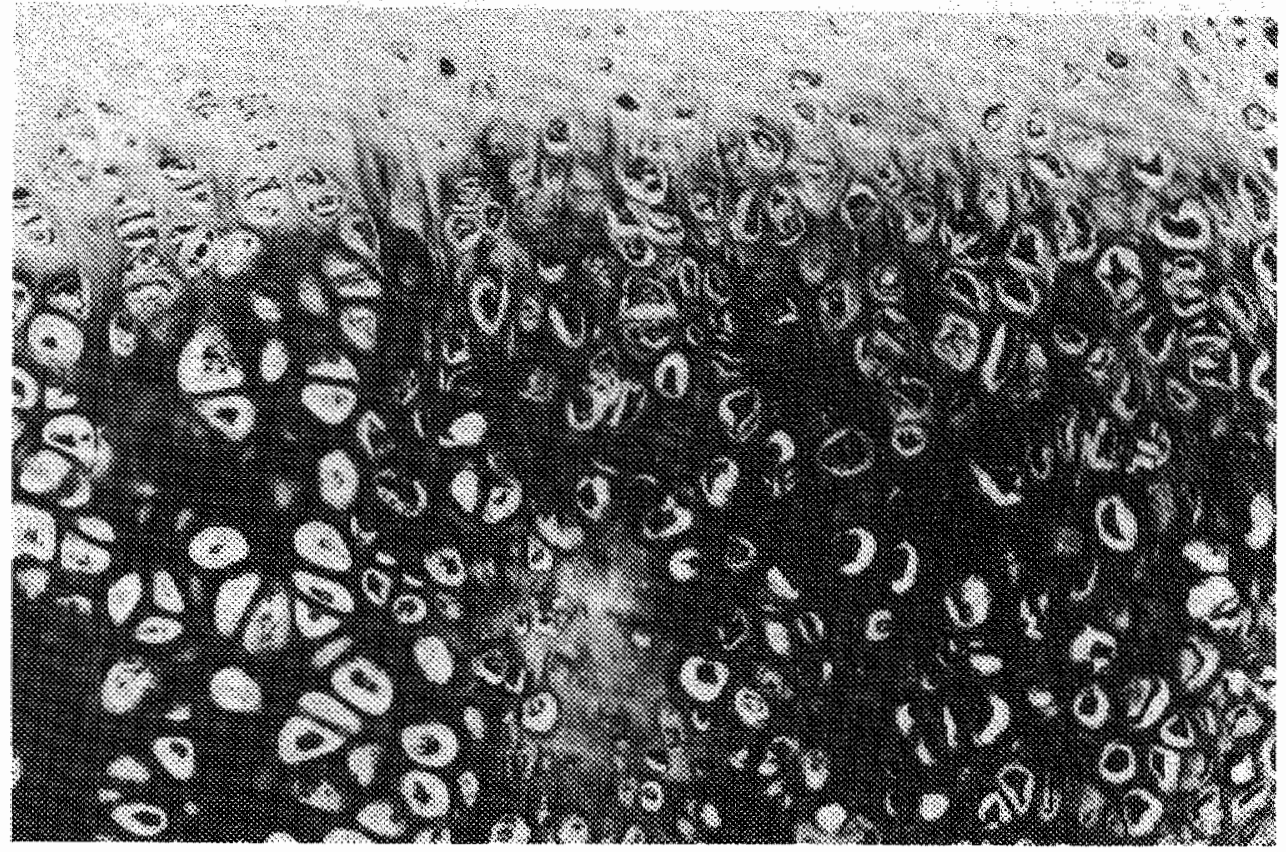

Figure 6.9.

Photomicrograph of the graft after 8 weeks: A high concentration of chondrocytes with large pericellular lacunae. Alcian Blue PAS x230.

\section{Four months $(n=10)$}

Normal appearing cartilage had formed out of the perichondrium. (Figure 6.10). This was microscopically confirmed (Figure 6.11 and 6.12). This neocartilage -average thickness $410 \mu \mathrm{m}$ (SD 240) resembled closely the specimens taken from the medial femoral condyle -average thickness 440 $\mu \mathrm{m}$ (SD 260)-. In the basal layer a very slight increase of the calcium staining could be seen.

The control defects showed partial repair and in all cases a depression was visible; sometimes smooth and dull and sometimes irregular and shining (Figure 6.13). The average thickness was $190 \mu \mathrm{m}$ (SD 140). In 6 specimens incompletely differentiated mesenchymal cells were seen without any sign of matrix production and closely resembling fibrous tissue (Figure 6.14). In 4 specimens a thin layer of chondrocytes had formed, randomly distributed in a scarcely stained matrix, having all the characteristics of fibrocartilage (Figure 6.15). 


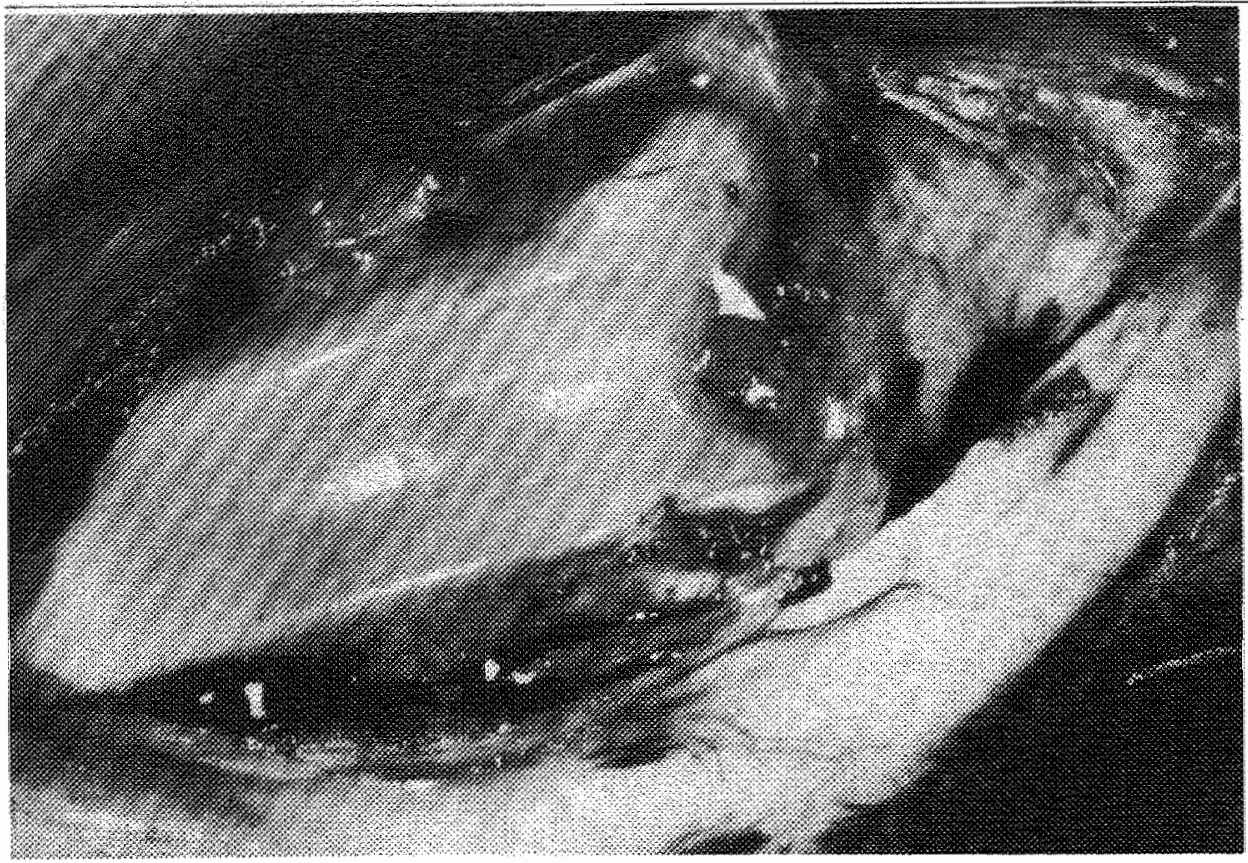

Figure 6.10.

Completely repaired cartilage defect of the intercondylar groove after 16 weeks.

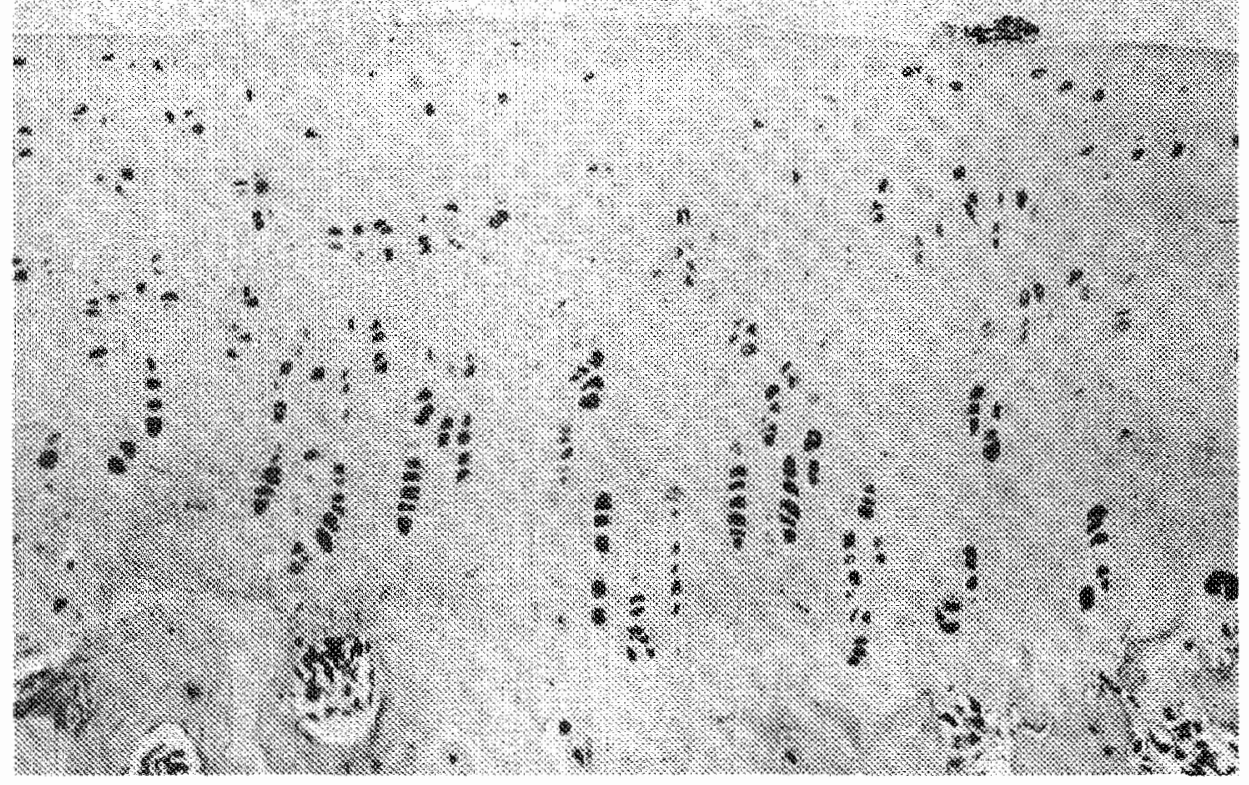

Figure 6.11.

Normal articular cartilage has generated from the perichondrial graft after 16 weeks. HE $\times 91$. 


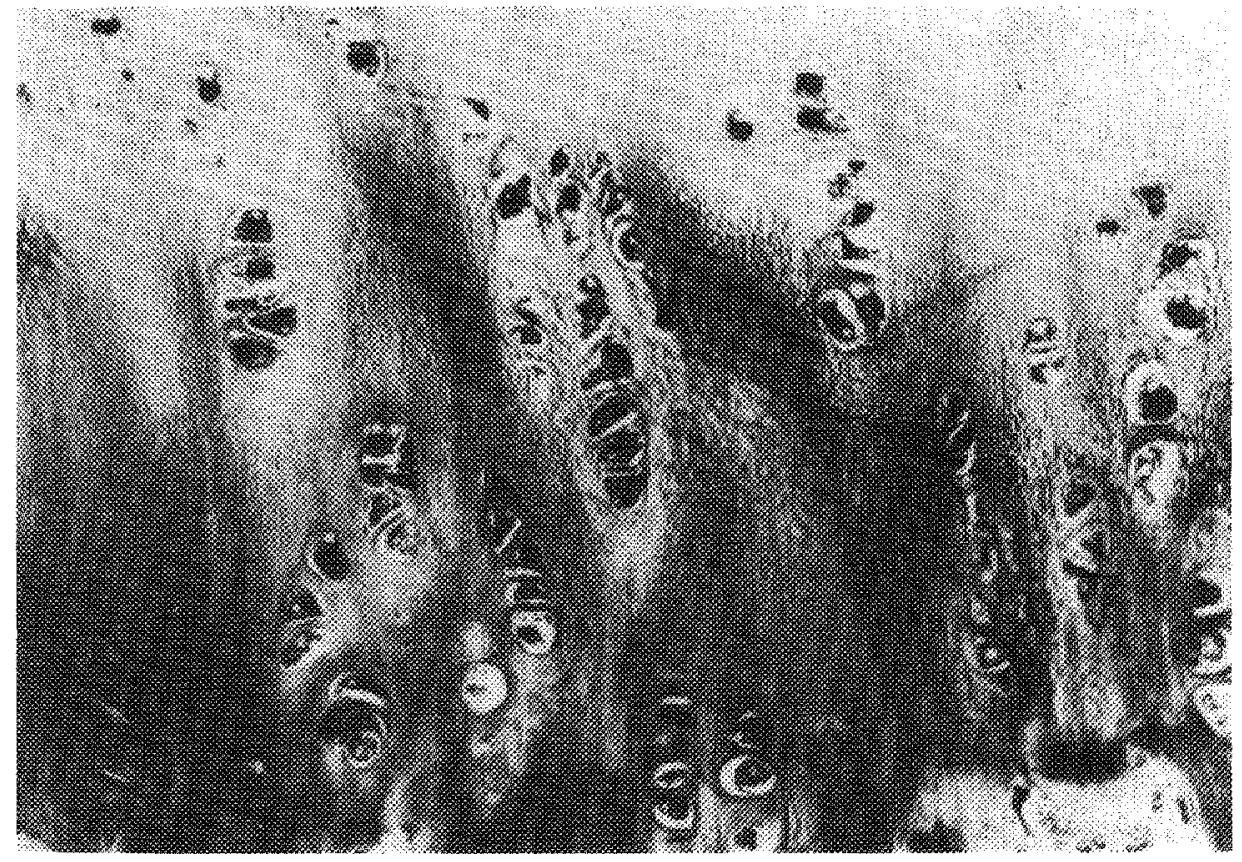

Figure 6.12

16 Weeks after perichondrial grafting: in the basal layer of the neocartilage normal chondrocytes are arranged in parallel; a close bonding between cartilage and subchondral bone is present. HE $\times 360$. 


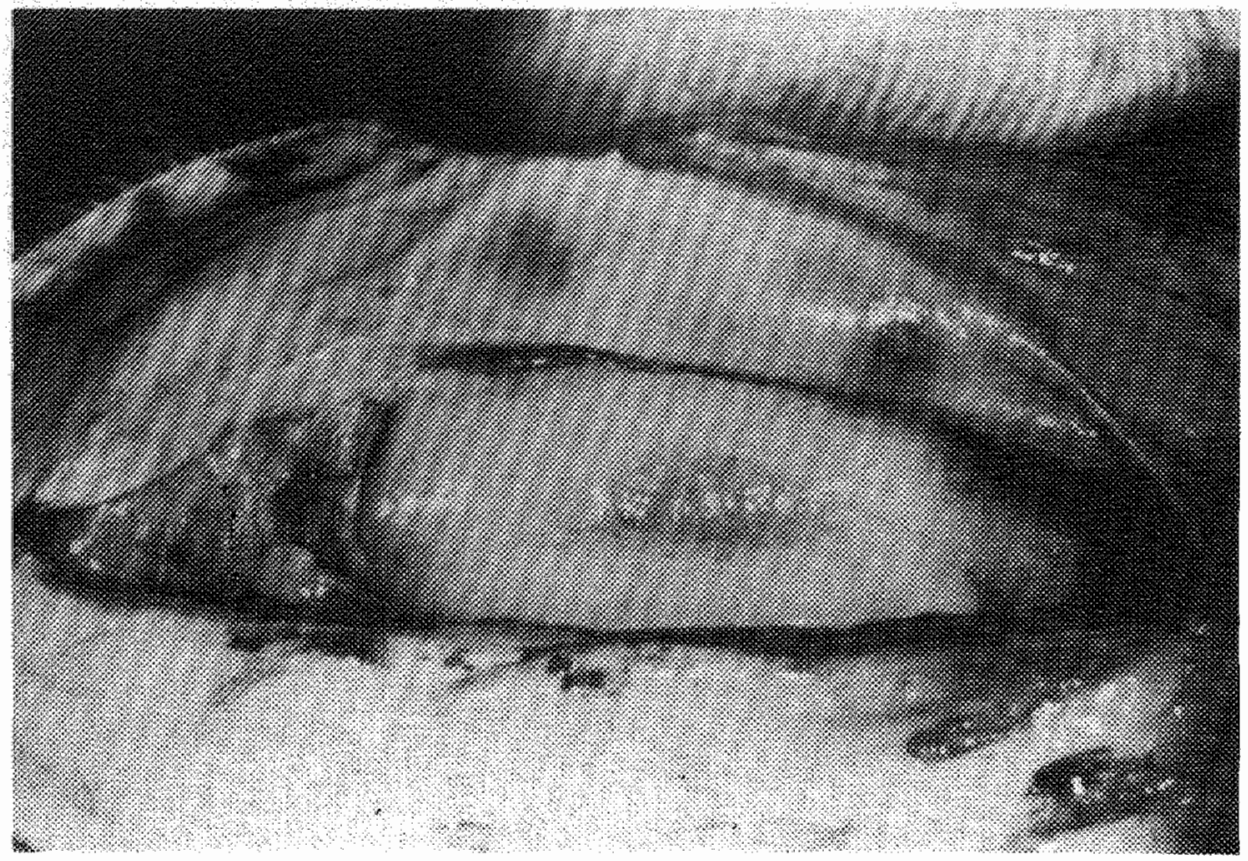

Figure 6.13

The control defect of the left knee after 16 weeks: The surface is irregular and the tissue formed has not reached the level of the joint surface.

\section{One vear $(n=8)$}

Macroscopically and histologically normal articular cartilage had formed, having all the qualities described before. The average thickness of the graft was $320 \mu \mathrm{m}$ (S.D.35) with 100 percent chondrocytes. In the control defect of 6 knees bare bone was found after one year. In the remaining 2 a thin fibrous layer covered the subchondral bone. With the calcium staining according to Eros (1988) an intense red staining of the basal layer of the cartilage was seen (Figure 6.16), which was absent in the biopsy taken from the non-grafted medial femoral condyle (Figure 6.17).

Roentgenograms taken after one year showed a regular and smooth lining of the subchondral bone and a normal mineralisation in the right knee. No calcification was seen in the cartilage layer (6.18). In the left knee the subchondral bone showed an irregular lining with a radiolucent line in the underlying cancellous bone (Figure 6.19). 


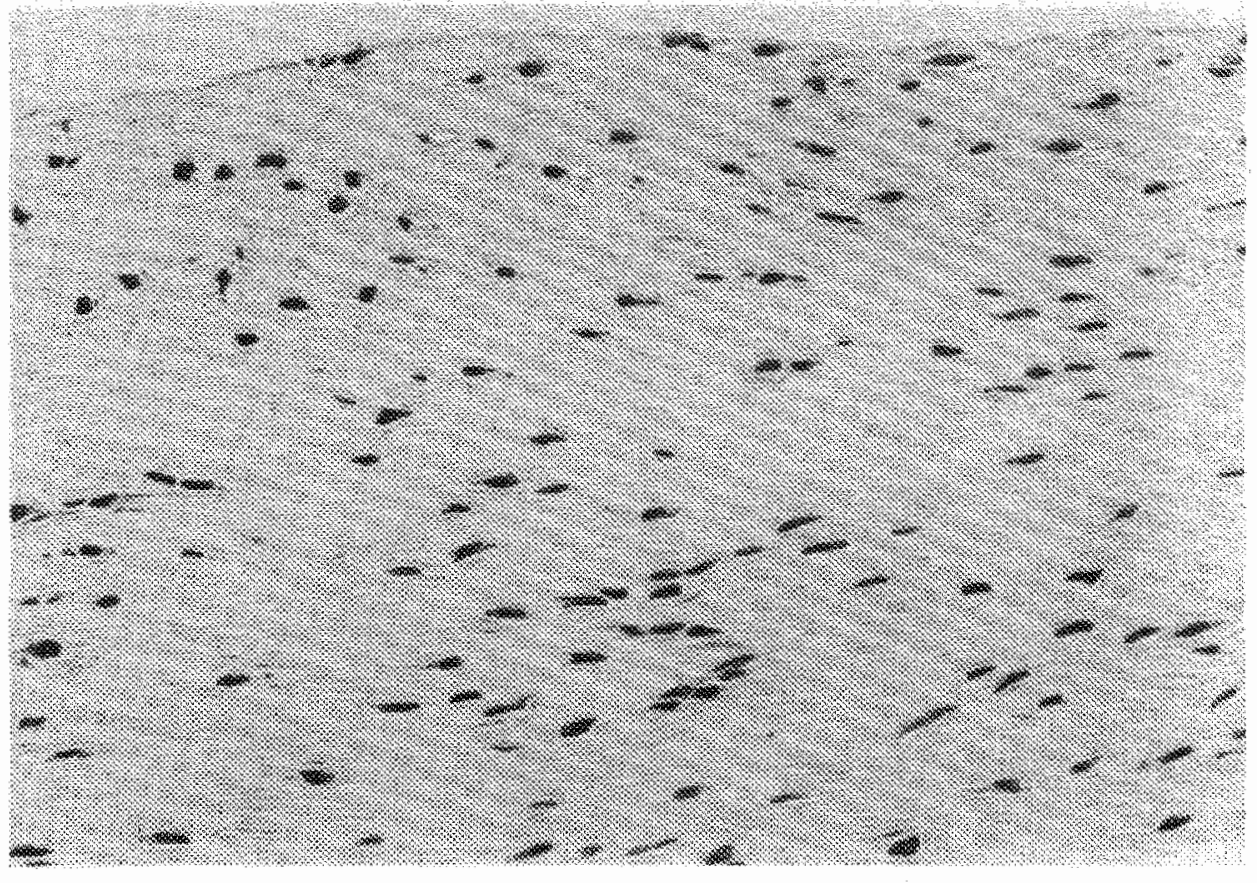

Figure 6.14

Specimen of one of the control defects after 16 weeks: Fibrocytes lying in a nonstaining intercellular matrix. HE $\times 91$.

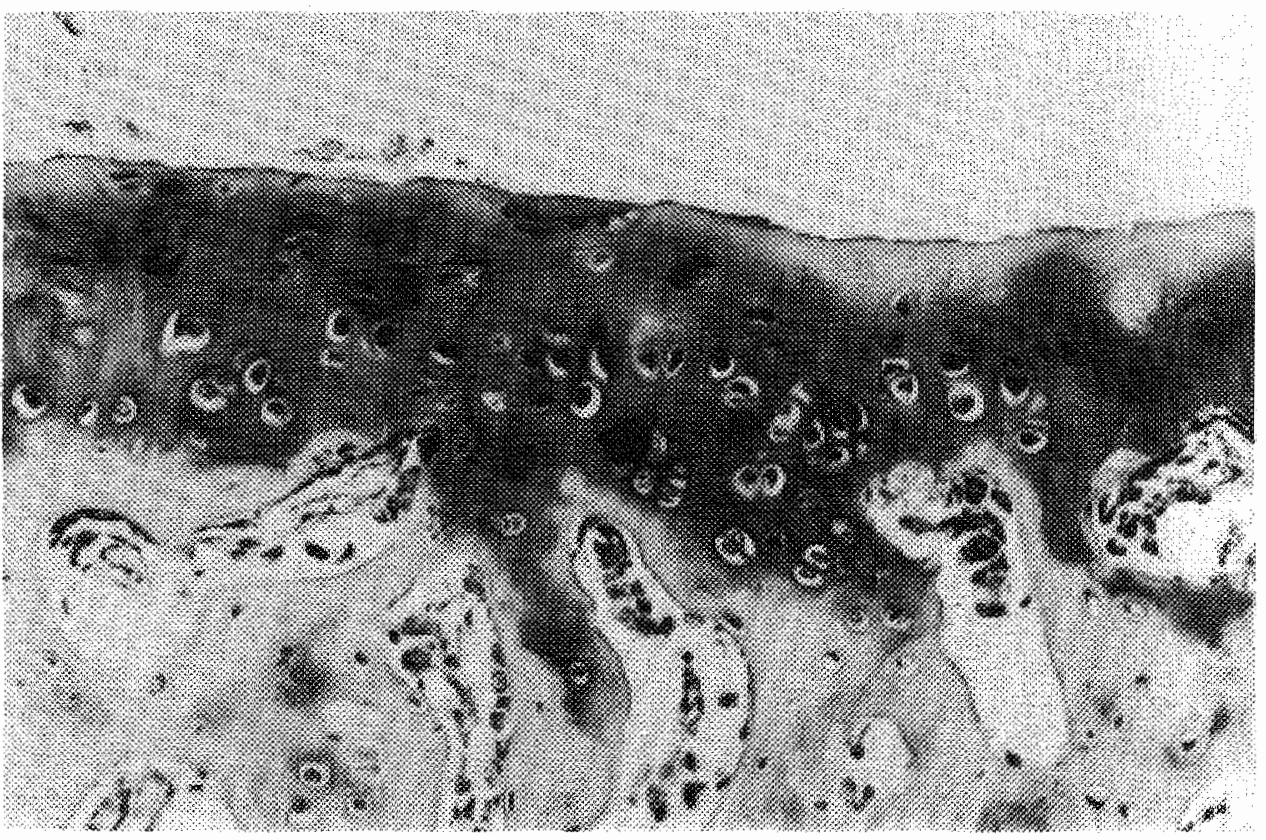

Figure 6.15

After 16 weeks fibrocartilage has developed in a minority of the defects: A thin layer with chondrocytes in a slightly staining matrix. Safranin $O \times 91$. 


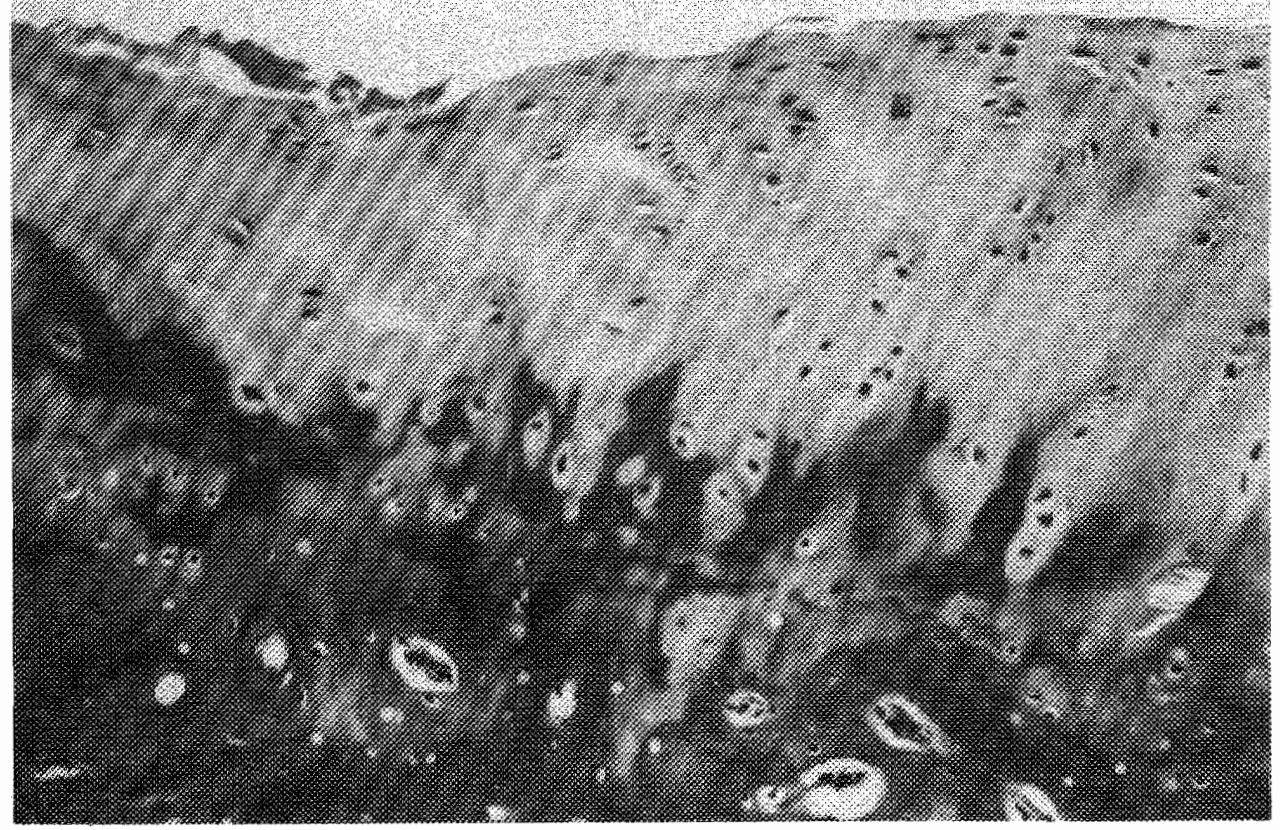

Figure 6.16

Calcium staining of the cartilage generated from a perichondrial graft after one year: Note the calcium staining of the basal layer compared with figure 6.17. Eros $\times 91$.

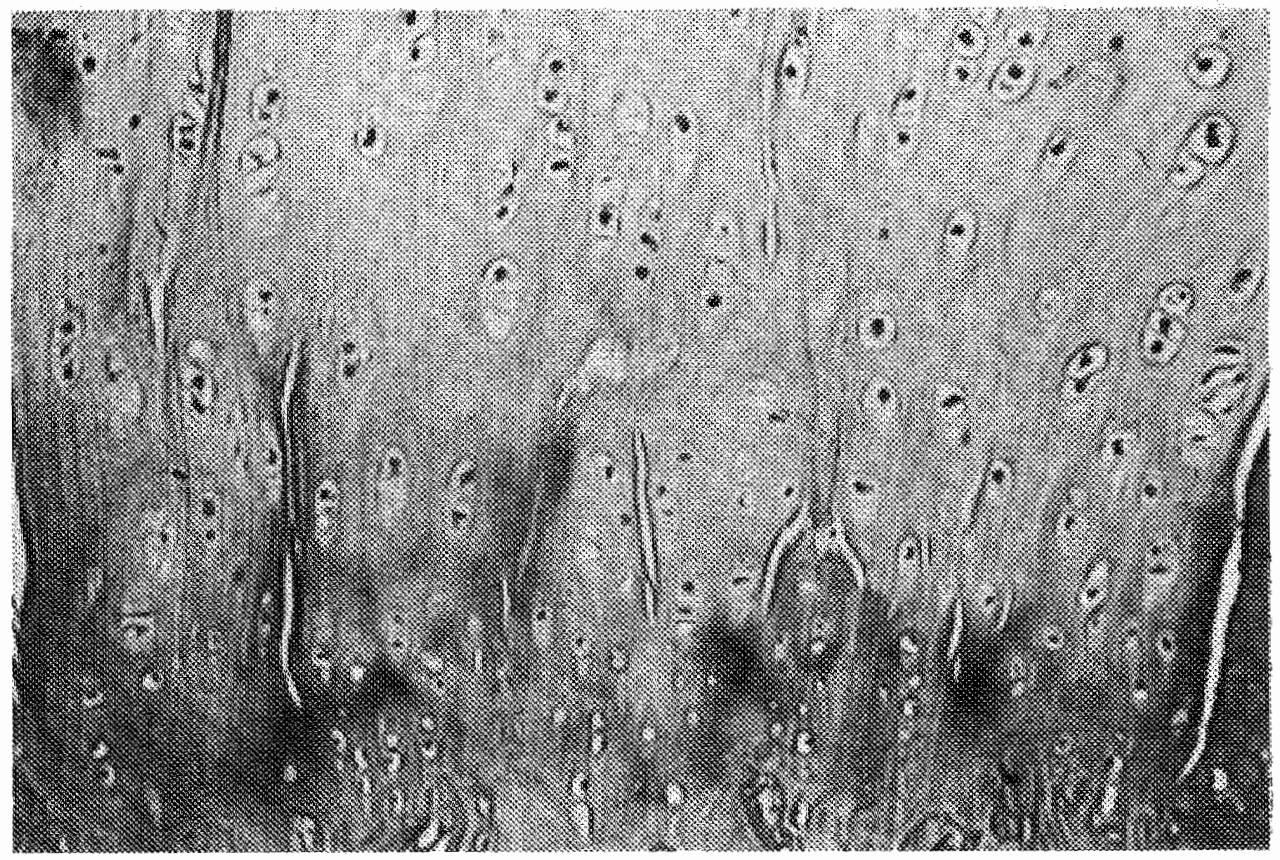

Figure 6.17

Calcium staining of a biopsy taken from the medial femoral condyle for control: No staining of the basal layer is visible. Compare with figure 6.16. Eros $\times 144$. 


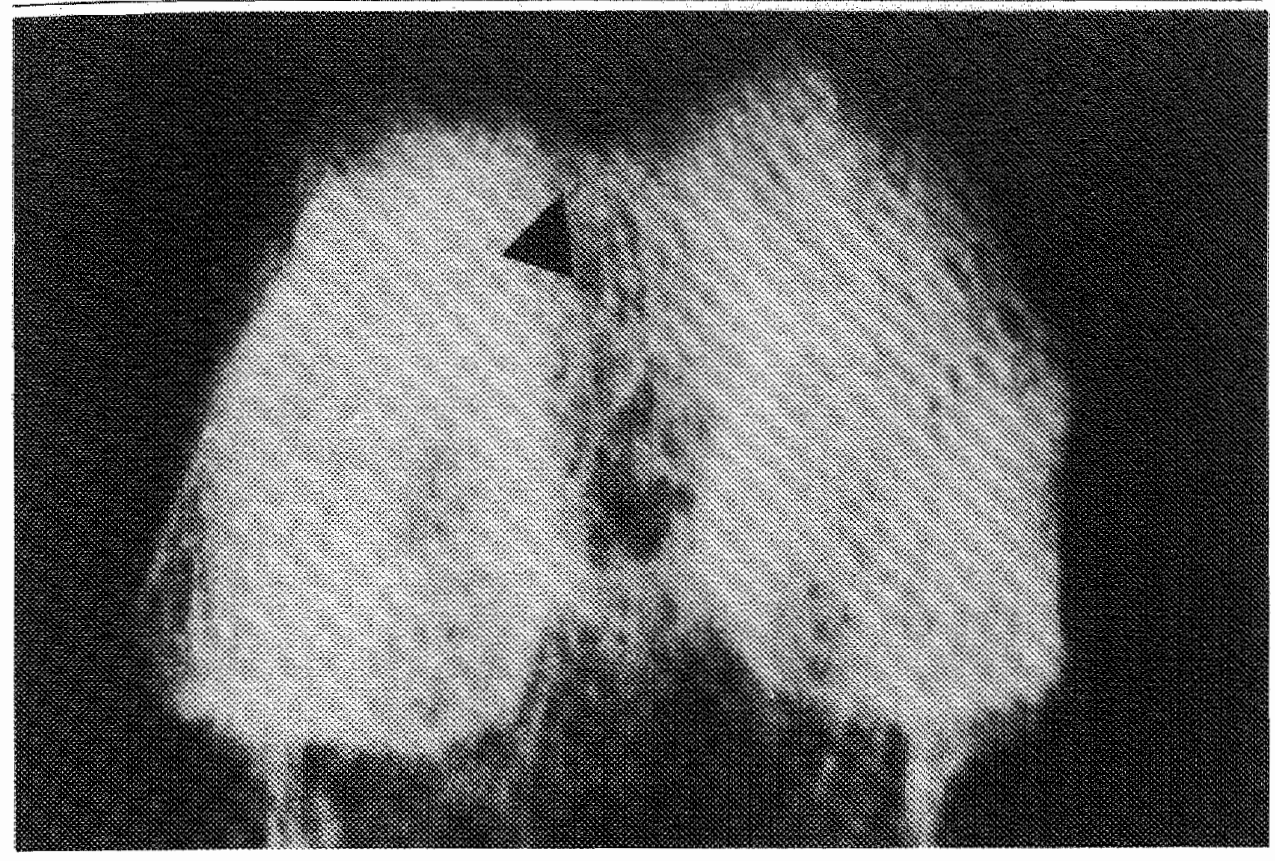

Figure 6.18

Roentgenogram of the rabbit's knee in axial direction one year after perichondrial grafting of the intercondylar groove. The subchondral bone is intact.

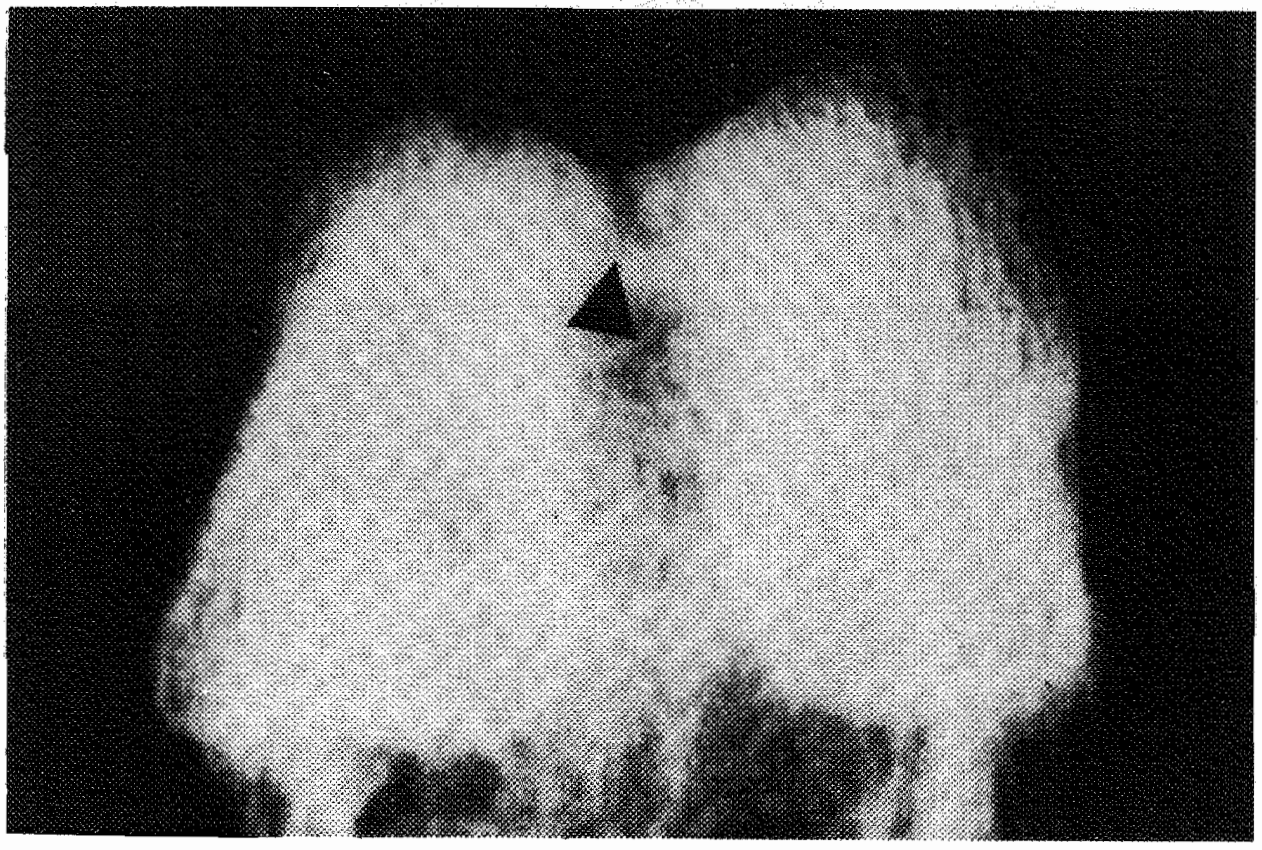

Figure 6.19

Roentgenogram of the rabbit's left knee in axial direction one year after creating a cartilage defect in the intercondylar groove (control): A radiolucent line is visible in the subchondral bone. 


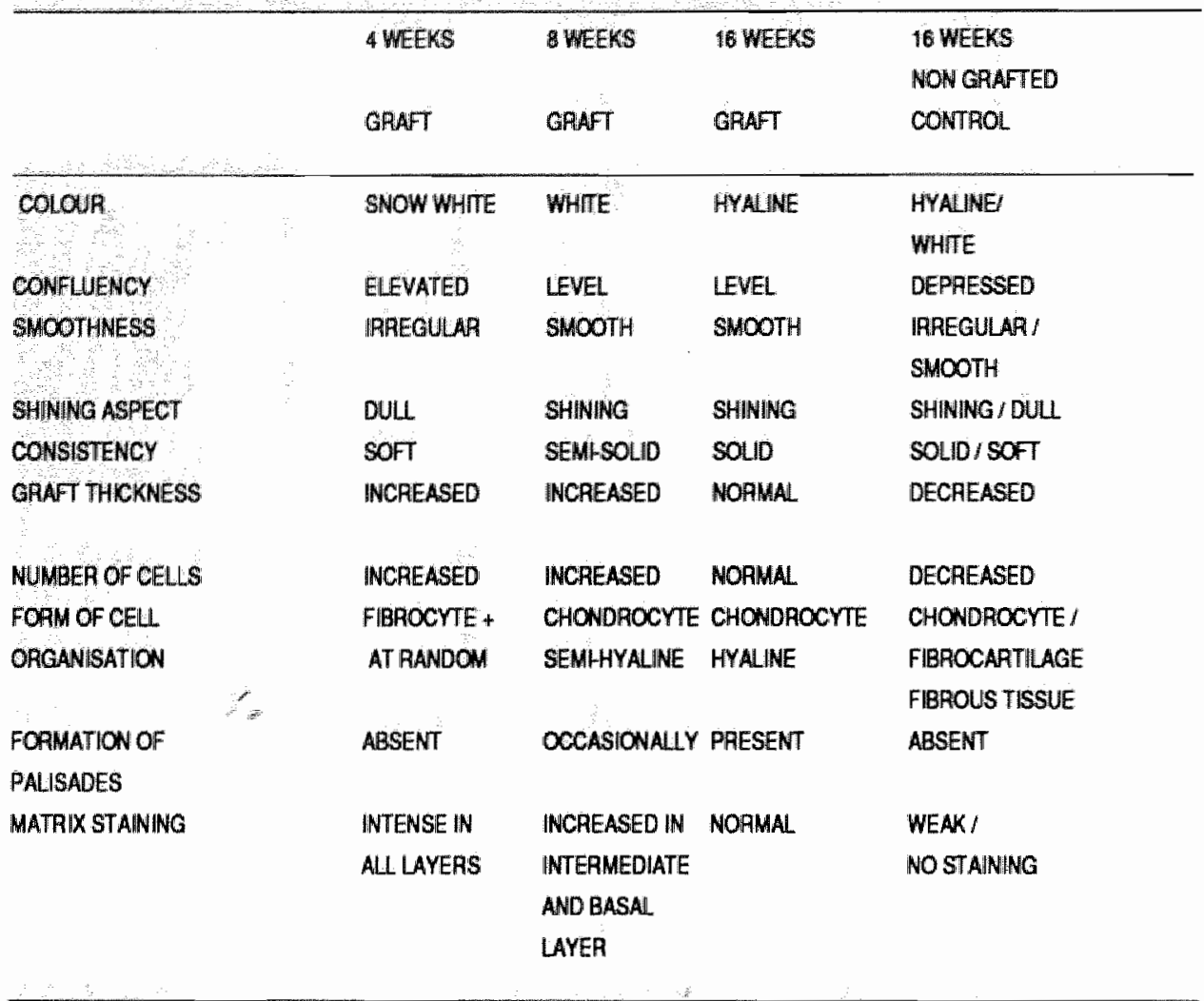

TABLE 6.1. MACROSCOPICAL AND HISTOLOGICAL GRADING OF THE NEWLY-FORMED TISSUE AFTER PERICHONDRIAL GRAFTING AND SPONTANEOUS HEALING AFTER SUBSEOUENT POST-TRANSPLANTATION TIMES. 


$\begin{array}{rll}\text { GRAFT } & \text { NUMBER OF } & \text { CELLS PER MM 2 PERCENTAGE } \\ \text { THICKNESSIN } \mu M & \text { DEEP LAYER } & \text { SUPERFICIALY CHONDROCYTES }\end{array}$

\begin{tabular}{|c|c|c|c|c|}
\hline PERICHONDRIUM & $\begin{array}{r}230 \\
(S . D .20)\end{array}$ & $\begin{array}{l}1040 \\
\text { (S.D.140) }\end{array}$ & $\begin{array}{l}710 \\
\text { (S.D.64) }\end{array}$ & \\
\hline \multicolumn{5}{|l|}{$N=7$} \\
\hline \multicolumn{5}{|l|}{4 WEEKS } \\
\hline GRAF; & $\begin{array}{r}1210 \\
\text { S.D. } 360)\end{array}$ & $\begin{array}{l}1812 \\
\text { (S.D.808) }\end{array}$ & $\begin{array}{l}1226 \\
\text { (S.D.396) }\end{array}$ & $\begin{array}{l}32 \\
\text { (S.D.27) }\end{array}$ \\
\hline CARTILAGE & $\begin{array}{r}340 \\
\text { (S.D.60) }\end{array}$ & $\begin{array}{l}1560 \\
\text { (S.D.266) }\end{array}$ & $\begin{array}{l}1240 \\
\text { (S.D.560) }\end{array}$ & 100 \\
\hline \multicolumn{5}{|l|}{$\mathrm{N}=9$} \\
\hline GRAFT & $\begin{array}{r}710 \\
\text { (S.D. } 440)\end{array}$ & $\begin{array}{l}335 \\
\text { (S.D.84) }\end{array}$ & $\begin{array}{l}1890 \\
\text { (S.D.11) }\end{array}$ & $\begin{array}{l}83 \\
\text { (S.D.28) }\end{array}$ \\
\hline CARTILAGE & $\begin{array}{r}380 \\
\text { (S.D.180) }\end{array}$ & $\begin{array}{l}1446 \\
\text { (S.D.434) }\end{array}$ & $\begin{array}{l}1160 \\
\text { (S.D.386) }\end{array}$ & $\begin{array}{l}94 \\
\text { (S.D.14) }\end{array}$ \\
\hline \multicolumn{5}{|l|}{$N=10$} \\
\hline GRAFT & $\begin{array}{r}410 \\
(S .0 .240)\end{array}$ & $\begin{array}{l}1028 \\
\text { (S.D.290) }\end{array}$ & $\begin{array}{l}834 \\
\text { (S.D.252) }\end{array}$ & 100 \\
\hline CARTILAGE & $\begin{array}{r}440 \\
\text { (S.D.260) }\end{array}$ & $\begin{array}{l}1088 \\
\text { (S.D.326) }\end{array}$ & $\begin{array}{l}952 \\
\text { (S.D. 128) }\end{array}$ & 100 \\
\hline $\begin{array}{l}\text { DEFECT LEFT } \\
\text { KNEE }\end{array}$ & $\begin{array}{r}190 \\
\text { (S.D.140) }\end{array}$ & $\begin{array}{l}1458 \\
\text { (S.D.516) }\end{array}$ & $\begin{array}{l}1342 \\
\text { (S.D.542) }\end{array}$ & $\begin{array}{l}37 \\
\text { (S.D.31) }\end{array}$ \\
\hline
\end{tabular}

TABLE 6.2. Quantitative data of histological specimens of the tissue formed after perichondrial grafting, a cartilage biopsy of the right knee and spontaneous healing of a non treated cartilage defect of the left knee.

Mean values are given. Thickness was measured in the middle of the graft or defect. Cells were counted over an area of $0.5 \times 0.05 \mathrm{~mm}$. SD is given in mean values. 


\subsection{Conclusions}

This experimental study confirms that perichondrium can be used to repair articular cartilage defects in rabbit knees. The histological development of perichondrium to cartilage is similar to that described by OhIsen and Widenfalk (1983). In our experiments we found great variation in graft thickness, cell number, and morphology at the same stage of repair (S.ee table 6.2). This reflects the fact that there is a great variation between grafts of different knees, although all grafts ultimately resulted in the formation of articular cartilage.

The two loose bodies, formed out of perichondrium contained $100 \%$ collagen II. This indicates that the biochemical quality of this cartilage is similar to that of hyaline cartilage.

We did not expose the cancellous bone by removing the subchondral bone. This did not impair the ingrowth of the graft as supposed by Engkvist et al. (1979). As a rule chondral lesions of the human knee do not affect the subchondral bone. In repairing these defects it might be important to leave the subchondral. bone intact as it may play an important role in preventing cartilage degeneration.

An elevated quantity of calcium was observed in the basal layer of the neocartilage. The same phenomenon was seen by Plenk and Passl (1980) who transplanted autologous pieces of cartilage into the knee of a sheep and found a raised level of mineralisation of the subchondral bone and of the basal layer of the graft. The possible influence on the biomechanical properties of the newly formed cartilage has still to be assessed.

Decreased quality or absence of articular cartilage influences the composition and structure of the underlying bone. One year after perichondrial grafting of an artificially created cartilage defect a normal subchondral bone structure was seen by radiological examination. In the knee with a nongrafted cartilage defect, the subchondral bone was irregular and a radiolucent line was seen in the cancellous bone. From this we can draw the following conclusion:

The natural repair process of an artificially created cartilage defect is insufficient to prevent destruction of the underlying bone. With a perichondrial graft no radiological change is seen in the underlying bone.

Graft fixation is a problem in perichondrial arthroplasty of major joints like the knee. Our study strongly indicates that fibrin glue gives a firm fixation of the graft when combined with an external fixation device.

No adverse reaction of the heterologous (human) fibrin glue was observed. The macroscopical, histological and radiological results of perichondrial grafting of cartilage lesions of the knee proved to be superior to the results of the natural healing process. 


\section{In vitro formation of cartilage from human adult costal perichondrium}

\section{1 introduction}

Engkvist et al.(1979) demonstrated the capacity of perichondrium to form cartilage in vitro. The aim of our experiment was to assess whether the same results may be achieved with adult human perichondrium.

Previously some doubts were expressed regarding the cartilaginous potential of adult perichondrium (Peer 1955). In the following experiments the in vitro chondrogenic potential of adult human perichondrium is examined. If this can be established more valid justification can be given to the clinical use of autologous perichondrial grafting of articular cartilage defects in adult man.

\subsection{Materials and methods}

Pieces of perichondrium were obtained from the ribs of adult patients $(n=12)$, average age 32 years. Explants measuring $10 \times 5 \mathrm{~mm}$ were transferred immediately after their removal to a sterile vial containing saline $(0.9 \% \mathrm{NaC} 1)$ and kept at $4^{\circ}$ Celsius. Within two hours after removal, the perichondrial explants were carefully examined under low magnification for residues of cartilage. Remaining cartilage was removed from the perichondrium. Dissection was performed with a thin bladed knife. All explants were cut into four pieces. Two parts were used for direct histological examination; the other two were used for culture (Bulstra et al. 1989).

Two criteria were used to determine the formation of cartilage:

- Autoradiography: The uptake of ${ }^{35} \mathrm{~S}$ suliphate, indicating the production of cartilage ground substance

- Histology: The histological appearance of the explant in terms of change of cell form, number of cells, matrix formation and thickness.

\subsection{In vitro culture technique}

Perichondrial explants were cultured in sterile petri dishes (Greiner, Nuertingen, FRG) in 2 ml of culture medium M199 (GIBCO, Paisley, UK) supple- 
mented with L-glutamine $250 \mathrm{mg} / \mathrm{ml}$, ascorbic acid $50 \mu \mathrm{g} / \mathrm{ml}$, antibiotic antimyotic solution $50 \mu \mathrm{g} / \mathrm{ml}$ containing $10.000 \mathrm{lU} / \mathrm{ml}$ penicillin, $10.000 \mu \mathrm{g} / \mathrm{ml}$ streptomycin and $25 \mathrm{mg} / \mathrm{ml}$ fungizone(GIBCO) supplemented with $10 \%$ of fetal calf serum (FCS). Every second day the medium was changed.

\subsection{Histology}

Explants were studied histologically before culture and at respectively 7 and 10 days after onset of the culture. They were fixed in neutral buffered formalin, embedded in paraffin and $5 \mu \mathrm{m}$ sections were cut. All sections were stained with haematoxylin and eosin, alcian blue periodic acid-Schiff (PAS) and safranin 0-fast green, a stain for glycosaminoglycans (GAG's). The thickness of the perichondrial explant, as well as the thickness of the newly synthesised cartilage layer was measured using a calibrated eyepiece micrometer in light microscopy. Each explant was measured on five different locations .

\subsection{Autoradiography}

After four days of culture the culture medium was supplemented with 15 $\mu \mathrm{Ci} / \mathrm{ml}^{35} \mathrm{~S}$ sulphate (specific activity $5 \mathrm{uCi} / \mathrm{mmol}$, the Radiochemical Center Amersham, UK). Subsequently the perichondrial explant was incubated for four hours. Afterwards the perichondrium was prepared for microscopical examination. Sections were dipped in 11 ford K-5 photographic emulsion , dried and stored in the dark at $4^{\circ} \mathrm{C}$. for 20 days. The autoradiographs were developed in Kodak D76 solution (Kodak, Buffalo, New York) and washed. The paraffin sections were examined unstained. In the central part of the explant the labeled cells were counted in an area of $2 \mathrm{~mm}^{2}$.

\subsection{Results}

Histological examination revealed the presence of residual cartilage on the inner layer of the perichondrium before culture in two specimens. Therefore these pieces were excluded from the study, remaining the cultures of 10 individuals for evaluation. Twenty consecutive cultures of perichondrium were performed. Two had to be excluded due to microbial infection.

\subsection{Histology of explant before culture}

When the perichondrium was dissected from the rib, the natural cleavage plane was easily found. The dissected perichondrium consists of a pliable layer, without macroscopic evidence of residual cartilage. The mean thickness of the human costal perichondrium proved to be 471 um (Table 7.1). 
The variation of the thickness of one perichondrial explant on five measurements proved to be less than $3 \%$. Histological examination of the human perichondrium showed three distinct cellular regions. The outer layer consists of fibrocytes longitudinally arranged: in the intermediate layer the celis contain oval-shaped nuclei. The inner layer adjacent to the rib cartilage consists of rounded cells with a pericellular lacuna. In three cases an area of scattered cells was present in contrast to the adjacent cartilage, not surrounded by alcian blue staining material. The perichondrial explant as a whole does not stain with safranin 0 or alcian blue, indicating the absence of glucosaminoglycans (GAG's). Thus perichondrium and cartilage can be discerned histologically by their matrix staining.

\subsection{Histology after 7 days of culture}

\section{See Table 7.1.}

One week after starting the culture, the perichondrial explants showed a marked increase in thickness from $471 \mu \mathrm{m}$ (SD 52) to $691 \mu \mathrm{m}$ (SD 63). Increase in thickness is statistically significant (paired T-test: $p<0.001$ ). The mean thickness of the newly formed cartilage layer measured $240 \mu \mathrm{m}$. There was a remarkable change in cell form and appearance. A hypercellular zone at the inner layer of the perichondrium had developed in all the cultured explants. The perichondrial cells had differentiated towards a layer with chondrocyte-like cells, having a round shape and a weak staining cytoplasm. The cells resided within a lacuna, surrounded by a zone of matrix, which stained intensely blue with alcian blue. The matrix stained with safranin 0 , indicating the presence of GAG's.

\subsection{Histology after 10 days of culture}

After 10 days of culture a further increase of the the thickness of the layer ocurred: mean thickness $746 \mu \mathrm{m}$ (SD 74). This increase, from the seventh day, is statistically significant (paired T-test: $p<0.01$ ). The mean thickness of the newly formed cartilage layer measured $300 \mu \mathrm{m}$. The differentiated cells showed the typical morphological characteristics of adult human chondrocytes (Figure 7.1). The cells had a rounded shape, lying isolated or together with an other cell within a lacuna. The intense staining of the zone directly around the lacunae suggests a further increase in the amount of GAG synthesised. Compared to the intensity of the staining with safranin $O$ after 7 days, a further increase of matrix staining was seen after 10 days.

\subsection{Autoradiography}

The autoradiographic studies showed a considerable ${ }^{35} S$ uptake in the perichondrial explant. The major part of the label was observed in the cells of the inner layer of the perichondrium (Figure 7.2), indicating a high pro- 
duction of cartilage ground substance of these cells. The grains indicating the presence of the uptake of the $35 \mathrm{~S}$ label were observed over the cells. The labeling index was determined with the use of light microscopy. It appeared that about $60 \%$ of the cells of the inner layer were labeled with ${ }^{35}$ S-sulphate, indicating that the major part of the cells of this layer took part in matrix production.

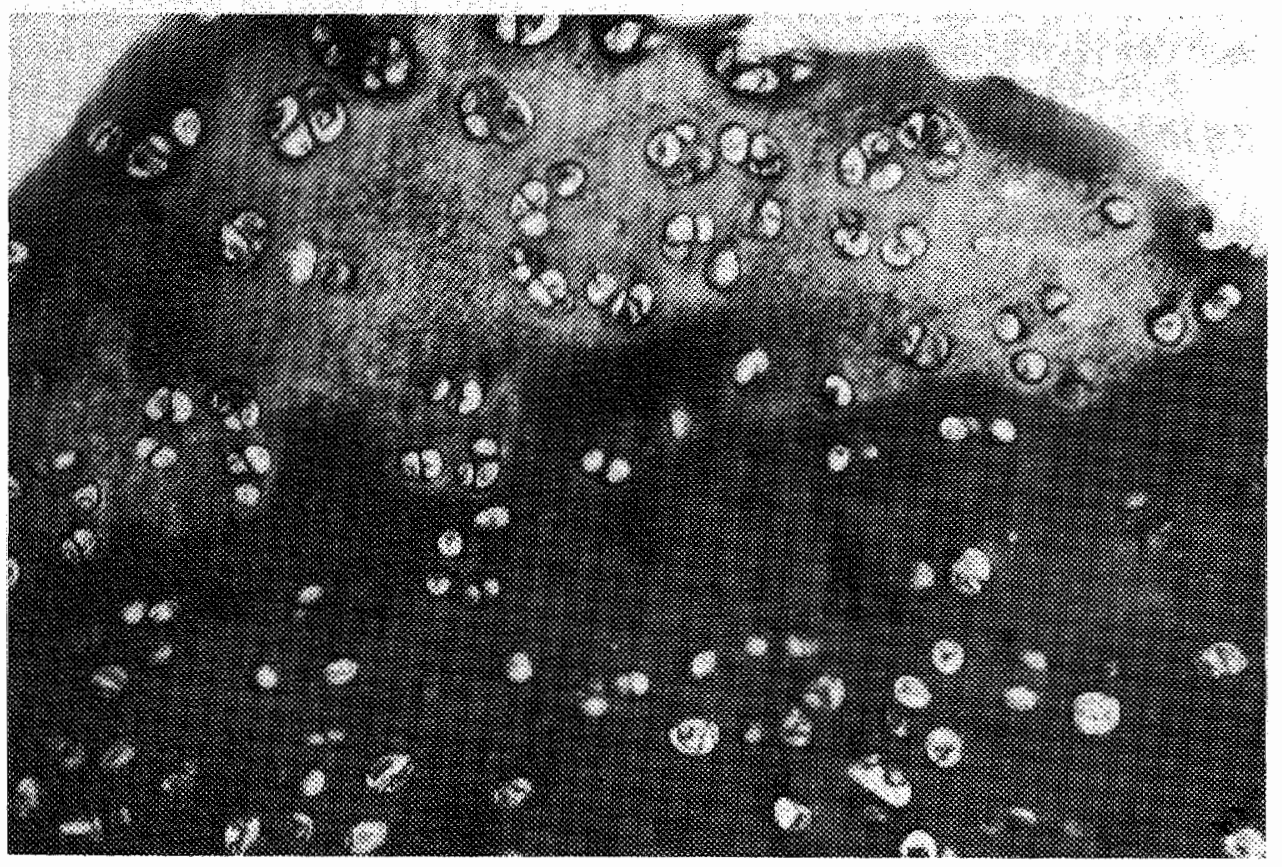

Figure 7.1

Adult human chondrocytes generated from perichondrium after 10 days in vitro culture. Safranin O $\times 91$.

\subsection{Discussion}

Adult human costal perichondrium histologically resembles perichondrium of a rabbit. The thickness of the perichondrium of these two species differs considerably: $230 \mu$ in the rabbit to $471 \mu \mathrm{m}$ in man. This culture study of human adult perichondrium confirms the chondrogenic capacity of perichondrium in vitro. These data strongly suggest that costal perichondrium from the adulthuman has the potential to form a sufficiently thick layer of hyaline cartilage. Therefore it may be useful to restore articular cartilage defects of major joints like the knee. 


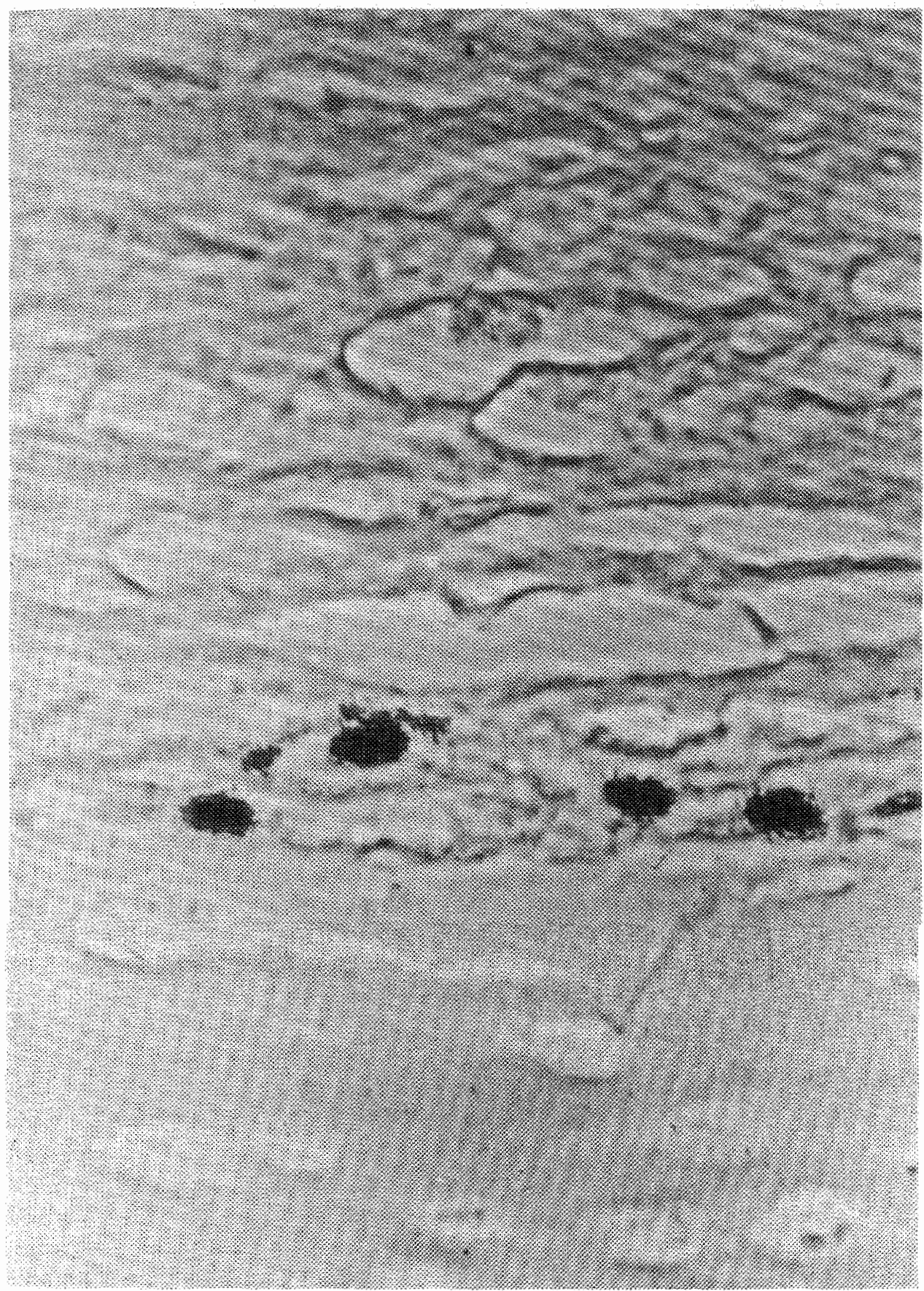

Figure 7.2

Grains of ${ }^{35} S$-sulphate uptake in the cells of the inner layer of the perichondrial explant after four days of culture. Magnification $\times 360$. 


\begin{tabular}{|c|c|c|c|}
\hline & $\begin{array}{l}\text { BEFORE } \\
\text { CULTURE }\end{array}$ & 7 DAYS & 10 DAYS \\
\hline $\begin{array}{l}\text { MEAN THICKNESS } \\
\text { OF EXPLANT }\end{array}$ & $\begin{array}{l}471 \mu \mathrm{m} \\
(\mathrm{SD} 52)\end{array}$ & $\begin{array}{l}619 \mu \mathrm{m} \\
(\mathrm{SD} 63)\end{array}$ & $\begin{array}{l}746 \mu \mathrm{m} \\
(\mathrm{SD} 74)\end{array}$ \\
\hline CARTILAGE LAYER & 0 & $\begin{array}{l}240 \mu \mathrm{m} \\
(\mathrm{SD} 42)\end{array}$ & $\begin{array}{l}300 \mu \mathrm{m} \\
(\mathrm{SD} 58)\end{array}$ \\
\hline
\end{tabular}

Table 7.1. The mean thickness of adult human perichondrium and the newly synthesised cartilage layer after 7 and 10 days of culture. 


\section{Perichondrial arthroplasty of the human knee}

\subsection{Introduction}

Nowadays symptomatic cartilage lesions of the knee are more often diagnosed because of the increasing use of the arthroscope.

Gillquist et al. (1977) found (osteo)chondral lesions in $10 \%$ of the patients with an acute injury of the knee.

Terry et al. (1988) identified 12 patients with chondral fractures in 312 consecutive knee arthroscopies; this is an incidence of $4 \%$.

All but one were able to recaill a specific mechanism of injury. All lesions were full-thickness. The average age of the entire study population was 32.4 years (range 15-67).

Johnson-Nurse and Dandy (1985) described 76 cases of fracture separation of articular cartilage in 72 patients. In 51 patients (67\%) a definite trauma was present. Twelve knees had ruptured cruciate ligaments. Twelve patients had meniscal lesions ( 7 medial and 5 lateral).

Sandberg and Balkfors (1988) reexamined 89 consecutive patients who had been operated on because of chronic insufficiency of the anterior cruciate ligament using the patellar tendon. The following cartilage lesions were seen (Classification according to Bauer and Jackson 1988):

Med.fem cond. Lat.fem.cond.

$\begin{array}{lrr}\text { None } & 55 & 70 \\ \text { Unknown } & 3 & 2 \\ \text { Grade 1 } & 3 & 2 \\ \text { Grade 2 } & 0 & 0 \\ \text { Grade 3 } & 10 & 1 \\ \text { Grade 4 } & 3 & 0 \\ \text { Grade 5 } & 15 & 14\end{array}$


Table 8.1. Cartilage lesions of the medial femoral condyle (med.fem.cond.) and lateral femoral condyle (lat.fem.cond.) in 89 patients 3.5 years after reconstruction of the anterior cruciate ligament.

\section{Number}

None

No information

Circumscript chondromalacia

Extensive chondromalacia

Old chondral fracture
56

5

20

5

1

Table 8.2. Number of cartilage lesions of the patella in 89 patients 3.5 years after reconstruction of the anterior cruciate ligament.

In summary: 68 Foci of chondral lesions were seen. Only 40 out of 89 patients had nó serious damage of the articular cartilage of their knee. It must be concluded that traumatic lesions of the cartilage of the knee are a common disorder and may be more or less symptomatic.

Other frequent causes of cartilage damage of the knee are:

Chondromalacia patellae

Osteochondritis dissecans

Crystal arthropathy e.g. chondrocalcinosis, pseudogout etc.

Justification for clinical application of perichondrial arthrosplasty of the knee.

In the Orthopedic Department of the University Hospital of Maastricht symptomatic cartilage lesions of the knee have been treated by removing degenerated cartilage and osteophytes and drilling of the subchondral bone according to Pridie (1956). The clinical results of this procedure were not in every case optimal. One of the main reasons being that the regenerated tissue derived from multipotent mesenchymal cells of the subchondral bone has the tendency to form fibrocartilage.

Perichondrial arthroplasty of smaller joints like the metacarpophalangeal joints and the interphalangeal joints of the finger may result in the formation of hyaline cartilage as was suggested by Engkvist and Johansson (1980), Sully et al. (1980) and Jackson et al. (1981). Grafting of a cartilage defect of the knee was reported in a case study by Hvid and Andersen (1981), who claimed repair of the lesion with articular cartilage after more than one year. The results of perichondrial arthroplasty in animal experiments together with the encouraging reports from clinical application in smaller joints formed the base for our decision to start treating symptomatic cartilage lesions of the knee with an autologous perichondrial graft of the rib. 
For the fixation of the graft fibrin glue was used because of its proven adhesive, nontoxic and biodegradable qualities.

The purpose of this prospective clinical study is:

-To establish the change in clinical condition by perichondrial arthroplasty of the knee,

-To observe the macroscopical aspect of the perichondrial graft by arthroscope from three months to one year after the operation,

- To study the histological features of a biopsy from the tissue generated from the perichondrial graft,

-To analyze the change in clinical condition in relation to the patients age, the preoperative delay and the graft location. In this way it may be possible to identify and predict conditions which may influence the final result, -To describe changes in radiological appearance of the knee after perichondrial grafting.

\subsection{Patients and methods}

From november 1986 on we started to treat patients with symptomatic cartilage lesions of the knee with a perichondrial graft of the rib. All patients were selected after a diagnostic arthroscopy. Informed consent was aquired from all patients before operation. Patients with radiological and arthroscopical evidence of generalised gonarthrosis were excluded from this kind of treatment. Most patients had been treated conservatively for a long time e.g. with temporary reduction of weight bearing, muscle strengthening excersises, physiotechnical applications or NSAID's. The mean time between the onset of the symptoms and the operation was 37 months (SD 37), range one month to twelve years. This implies that a majority of the patients had complaints for more than 2 years. Two patients were operated within three months after a traumatic event.

The professional status of the patients at the time of operation is shown in Table 8.3.

Thirty cartilage lesions of the knee in 25 patients were treated by perichondrial arthroplasty: 12 right and 13 left knees of 20 men and 5 women. Mean age at the time of operation 31 years (SD 8), range 18-45 years.

Etiology of the cartilage lesions.

Ten lesions were of traumatic origin. Three cartilage defects were caused by osteochondritis dissecans and had previously been treated by drilling the subchondral bone. Five times chondromalacia patellae was the supposed cause of a chondral lesion. Five times no cause could be pointed out. Seven times degeneration of cartilage had taken place: two times chondrocalcinosis was present and five times no specific cause could be identified. 


\begin{tabular}{|c|c|c|c|c|c|}
\hline NUMBER & SEX & AGE & PROFESSION & KNEE & \\
\hline & & & & PRE & POST \\
\hline 1. & M & 35 & Bookkeeper & 87 & 96 \\
\hline 2. & $F$ & 45 & Housewife & 66 & 89 \\
\hline 3. & M & 45 & Unemployed & 62 & 86 \\
\hline 4. & $M$ & 31 & Unemployed & 71 & 80 \\
\hline 5. & $F$ & 41 & Unemployed & 66 & 87 \\
\hline 6. & $\mathrm{~F}$ & 23 & Student & 75 & 76 \\
\hline 7. & M & 26 & Clerk & 72 & 98 \\
\hline 8. & $M$ & 32 & Clerk & 56 & 75 \\
\hline 9. & $M$ & 27 & Lab techn. & 81 & 98 \\
\hline 10. & M & 32 & Labourer & 78 & 100 \\
\hline 11. & $M$ & 23 & Clerk & 58 & 93 \\
\hline 12. & M & 24 & Nurse & 63 & 96 \\
\hline 13. & $M$ & 35 & Shopkeeper & 79 & 90 \\
\hline 14. & M & 35 & Labourer & 72 & 59 \\
\hline 15. & $M$ & 24 & Mechanic & 90 & 94 \\
\hline 16. & $F$ & 30 & Secretary & 78 & 100 \\
\hline 17. & $\mathrm{~F}$ & 20 & Student & 73 & 97 \\
\hline 18. & M & 30 & Driver & 75 & 90 \\
\hline 19. & M & 42 & Carpenter & 81 & 92 \\
\hline 20. & $M$ & 46 & Painter & 69 & 93 \\
\hline 21. & M & 23 & Labourer & 76 & 88 \\
\hline 22. & M & 38 & Operator & 73 & 97 \\
\hline 23. & M & 45 & Mechanic & 64 & 80 \\
\hline 24. & $M$ & 18 & Student & 83 & 100 \\
\hline 25. & M & 28 & Waiter & 87 & 100 \\
\hline
\end{tabular}

TABLE 8.3. Personal data of each patient and change in kneescore

Previous surgery

11 patients had operative treatment before, mainly consisting of removal of degenerated cartilage and drilling of the underlying bone. Lateral release was done in three cases of chondromalacia patellae. One patient, with severe chondromalacia patellae, had undergone a Maquet procedure of the knee, three years before, without result.

Knee score

Before operation a detailed knee assessment sheet was filled, which scored symptoms, signs and effect on daily activities, work and sports activities. This sheet was used to give every patient a kneescore 
between 0 and 100 (Table 8.3), according to the knee assessment sheet of the Hospital of Special Surgery (Ranawat 1976: Table 8.4).

\section{Radiological examination}

Before operation X-rays of the affected knees of all patients were taken in anteroposterior, lateral and patella axial view position. In seven knees osteophytes were present (Fairbanks grade one).

Three cases with an old osteochondritis dissecans, previously treated by drilling of the subchondral bone, showed an irregular calcification in the cartilage zone at the affected side. In five patients with cartilage lesions of the patella , a dysplastic or/and a subluxating patella was seen. Two knees showed a slight calcification in the medial and lateral tibiofemoral joint space which was interpreted as a sign of chondrocalcinosis.

The indication for the operation was made after arthroscopy (Figure 8.4a). Attention was paid to the type of lesion regarding the following characteristics: Location of the defect, fibrillations, flap tears, visibility of the bone and extension of the lesion. If necessary a hook was used to assess whether the chondral lesion reached the underlying bone.

All 30 lesions were classified according to Bauer and Jackson(1988) and are listed in Table 8.5:

Type of llesion

Number

One

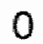

Two

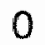

Three

Four

Five

Six

TABLE 8.5. Classification of cartilage lesions. Type 1: Line crack lesion; type 2: Stellate fracture type; type 3: Flap type; type 4: Crater type; type 5: Fibrillation type; type 6: Degrading type.

The most prevalent places of cartilage lesions in our group of patients were at the lateral (intercondylar) side of the medial femoral condyle and the medial and central part of the patella. Table 8.6. enumerates the number of lesions at the various locations. 


\section{KNEE DISABULITY ASSESSMENI}

1. PAIN 30 points

1. No pain at any time 30

2. No pain on walking 15

3. Mild pain on walking 10

4. Moderate pain on walking 5

5. Severe pain on walking : 0

6. No pain at rest 15

7. Mild pain at rest 10

8. Moderate pain at rest 5

9. Severe pain at rest 0

2. FUNCTION-22 points

A1. Waking and standing unlimited $\quad 12$

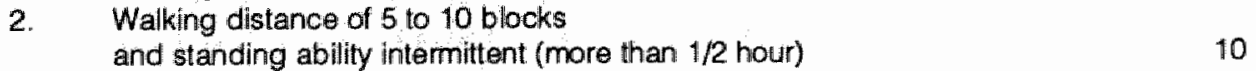

3. Walking 1 to 5 blocks and standing
ability up to $1 / 2$ hour

4. Walk less than 1 block 4

5. Can't walk, $\quad 0$

B1. Climb stairs $\quad 5$

2. Climb stairs with support 2

3. Transfer activity 5

4. Transter activity with support 2

3. ROM-18 points

1. 1 point for each $B$ of arc of motion-maximum of 18 points

4. MUSCLE STRENGTH-10 points

1. Good-Can't break quadriceps power 10

2. Good-Can break quadriceps power $\quad 8$

3. Fair-Moves through arc of molion 4

4. Poor-Can't move through arc of motion 0

5. FLEXION DEFORMITY-10 points

1. No deformity 10

2. Fow degrees 8

3. 5-10 degrees 5

4. 11 degrees or more 0

INSTABULITY-10 points

1. None 10

2. Mild- 0-5 degrees 8

3. Maderate-6-15 degrees $\quad 5$

4. Severe- 16 or more 0

Remarks: Substract 1 point lor using a cane, 2 points for 1 crutch and 3 points for 2 crutches. Two points for 5 degrees of extension lag. 3 points for 10 and 5 points for 15 or more. One point for 5 valgus and varus deformities.

TABLE 8.4. Ranawat et all. 1976. 
Number

Medial femoral condyle 15

Patella

Lateral femoral condyle Intercondylar groove

TABLE 8.6. Localisation of the cartilage lesions $(n=30)$.

The size of the graft varied from 1 to $5 \mathrm{~cm}^{2}$ (mean 2,13 $\mathrm{cm}^{2}$ ).

In two cases a ruptured anterior cruciate ligament was diagnosed with clinical signs of instability.

\subsection{Surgical procedure}

All operations have been performed by the author.

General anaesthesia is used. The affected leg is made bloodless. Leg and chest wall are cleaned with iodine and draped with sterile cloths.

The knee is opened through a medial parapatellar incision and the patella is dislocated laterally. The chondral lesion is identified and cleaned to the subchondral bone. The osseous bone plate is not removed or perforated to reach the cancellous bone, but scraped with a sharp spoon until point haemorrhages are seen. The lesion is extended into the surrounding cartilage creating a perpendicular border with a sharp edge (Figure 8.1.).

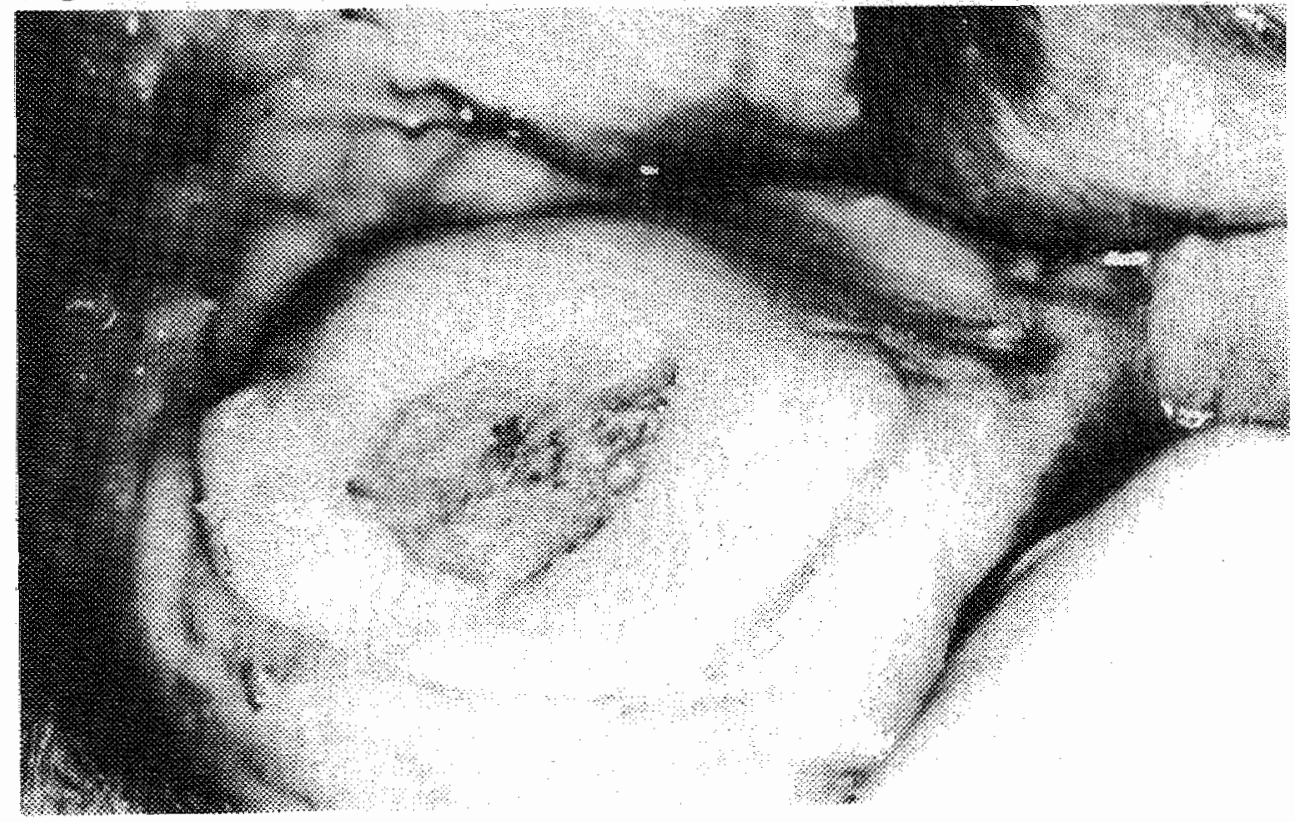

Figure 8.1

A cartilage defect of the patella after removal af remnants of degenerated and damaged cartilage up to the subchondral bone. A sharp border is created into the sound surrounding cartilage. 
An oblique incision is made over the lower part of the left side of the chest. The fascia of the rectus abdominis muscle is split transversely and the muscle fibers are split longitudinally, in line of its fibers. The ribs are cleaned of remaining muscle fibers and fat. At the inferior part of the costal arc, the sixth and seventh rib have the broadest surface. Here the perichondrium is incised and separated from lateral to medial from the underlying cartilaginous part of the rib. This is done with as little adhering cartilage as possible. The perichondrium is removed together with its chondrogenic layer dissecting it through the natural cleavage plane (Figure 8.2).

The size of the graft is cut down to the size of the defect. Sometimes it is necessary to use two pieces of perichondrium.

When the knee is opened and the cartilage lesion considered to be suitable for perichondrial grafting, the preparation of Tissucol( $\mathrm{R})$, a fibrin glue, is started. Fibrinogen $(70-110 \mathrm{mg} / \mathrm{ml})$ is mixed with aprotinin $(3000 \mathrm{KIE} / \mathrm{ml})$ and thrombin (4I.E.) with calciumchloride $(40 \mathrm{mmol} / 1)$. These mixtures are heated to $37^{\circ} \mathrm{C}$ in the Fibrinotherm, a warming and stirring device. The fibrinogen vial is placed in the opening with the magnetic stirrer. When complete reconstitution has taken place the components are drawn into

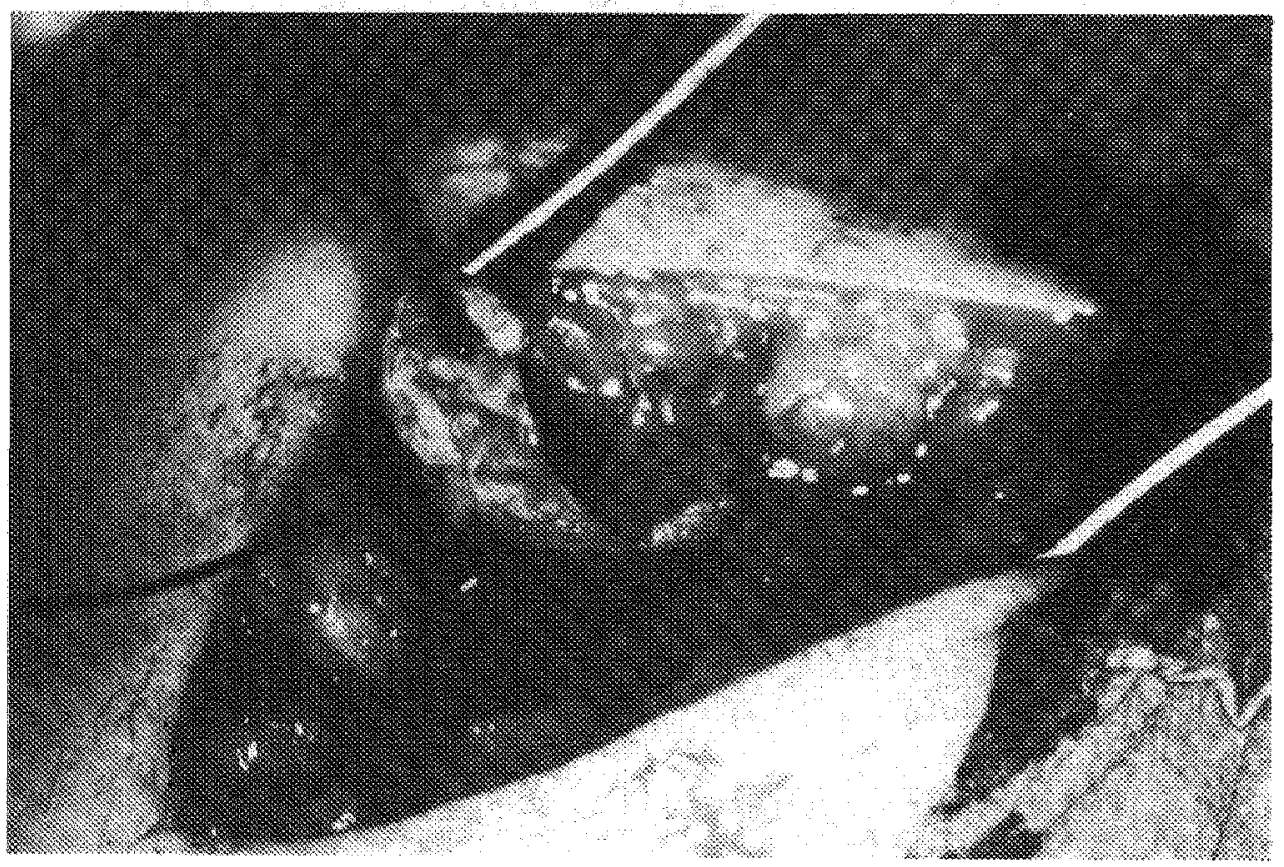

Figure 8.2

Dissection of the perichondrium through the natural cleavage plane, from the cartilaginous part of the rib. 
sterile syringes, which are placed in the Duploject system. The two components are applied simultaneously to the cartilage defect. The perichondrial graft is placed on the subchondral bone with the chondral side facing the knee joint after which it is firmly pressed to the subchondral bone with a wet gause for one minute. After closing the wounds a Robert Jones bandage is applied around the leg together with a dorsal slab of P.O.P.

Two weeks after the operation the P.O.P. is removed and the leg is placed on a motor unit for continuous passive motion (C.P.M.) (Figure 8.3).

For grafted lesions of the patella or intercondylar groove, flexion is restricted to $30^{\circ}$. From the fourth week after operation the patient is allowed out of bed and to walk with crutches without putting weight on the operated leg. Active and frequent movement of the knee joint is encouraged. Patients with an arthroplasty of the patellofemoral joint get a hinged cast to restrict flexion to $30^{\circ}$.

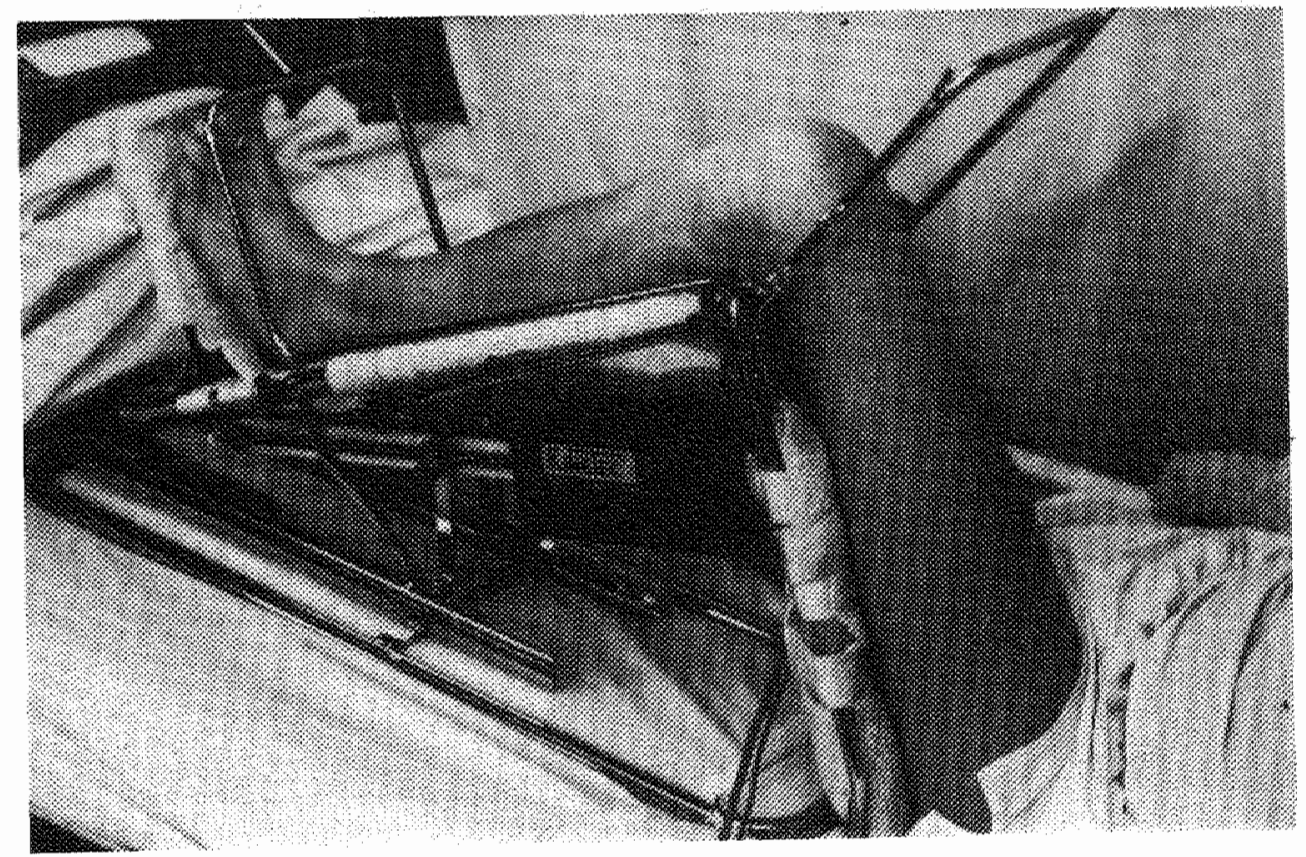

Figure 8.3

The leg is placed on a motor unit for continuous passive mation(CPM). 
Three months after operation the cast, if present, is removed and full weight bearing is permitted.

In two patients at the same time cartilaginous loose bodies were removed from the knee joint during the operation.

In two patients with instability of the knee, due to a ruptured anterior cruciate ligament ${ }_{\text {p }}$ perichondrial arthroplasty was combined with a reconstruction of the anterior cruciate ligament with the central part of the patellar tendon.

\subsection{Results}

The results of perichondrial arthroplasty was assessed by means of:
A. Arthroscopy $(n=25)$
B. Biopsy of the graft $(n=3)$
C. Radiological examination $(n=25)$
D. Knee score after one year $(n=25)$

\section{A. Arthroscopy,}

Arthroscopy was performed in all 25 knees from three months to one year after operation (average 10 months). Of the 30 grafted cartilage defects 27 showed a complete filling of the defect with tissue resembling cartilage. In two cases an unchanged crater type defect of the weight bearing part of the medial femoral condyle was seen. One patellar graft location was covered with a white tissue though the surface was fibrillated.

Sometimes it was difficult to find the grafted place because no visible border could be seen between the newly formed tissue and the surrounding cartilage (Figure $8.4 \mathrm{~b}$ ).

In these cases identification of the graft was only possible by a slight difference in colour: the grafted place being more white than the rest of the cartilage.

In six cases the transplant was elevated above the level of the surrounding articular surface (Figure $8.5 \mathrm{~b}$ ). In the first 6 months all grafts were elevated while after one year, only those cartilage defects which had been treated in the past by drilling the subchondral bone showed this phenomenon. A hook was always used to assess the consistency of the graft. In 20 cases the surface of the graft was soft though a solid structure was felt below. This superficial imprintability seemed to diminish with the increase of the postoperative time. 


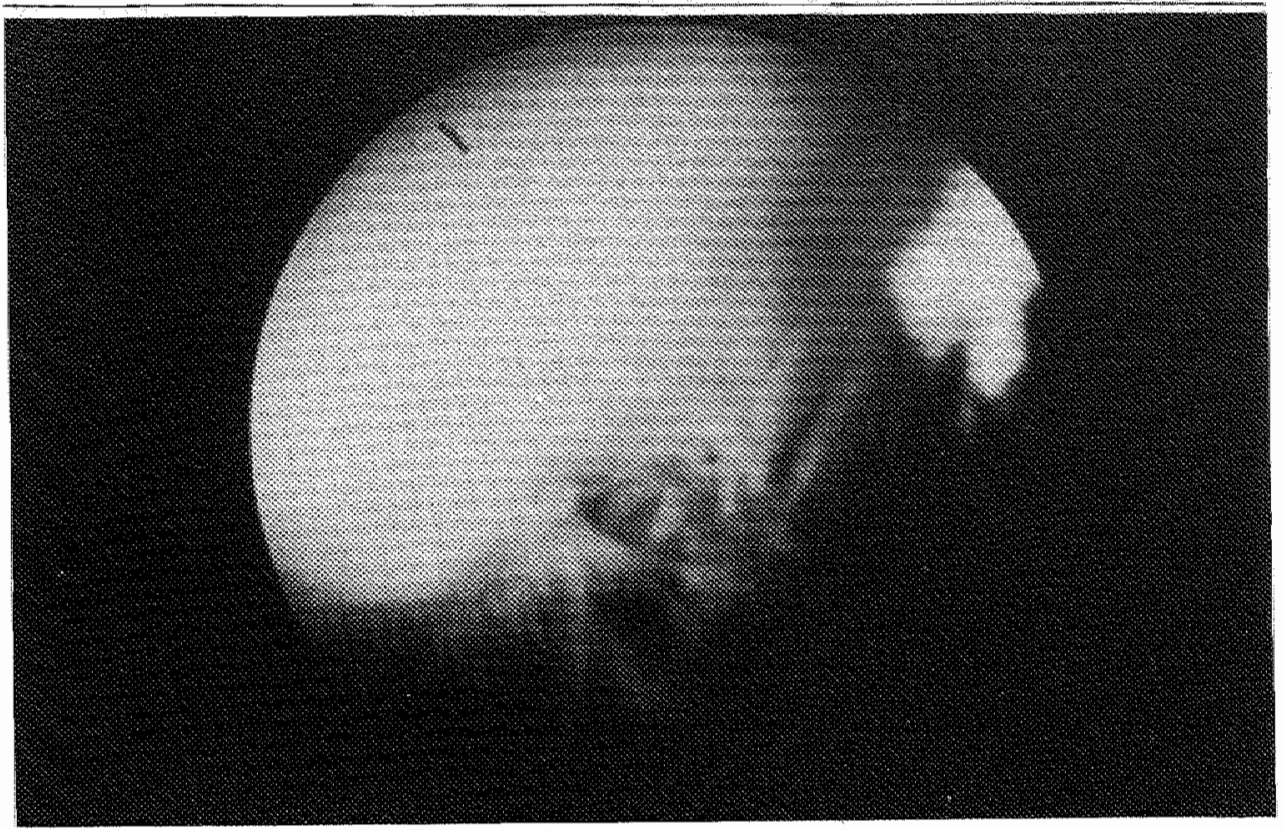

\section{Figure $8.4 a$}

Anthroscopy, before operation, of a cartilage defect with fibrillations of the weight bearing part of the medial femoral condyle.

\section{Figure 8.4b}

Anthroscopy of the same defect, one year after perichondrial grafting. The defect has completely filled up with articular cartilage resembling tissue, in level with the joint surface. 


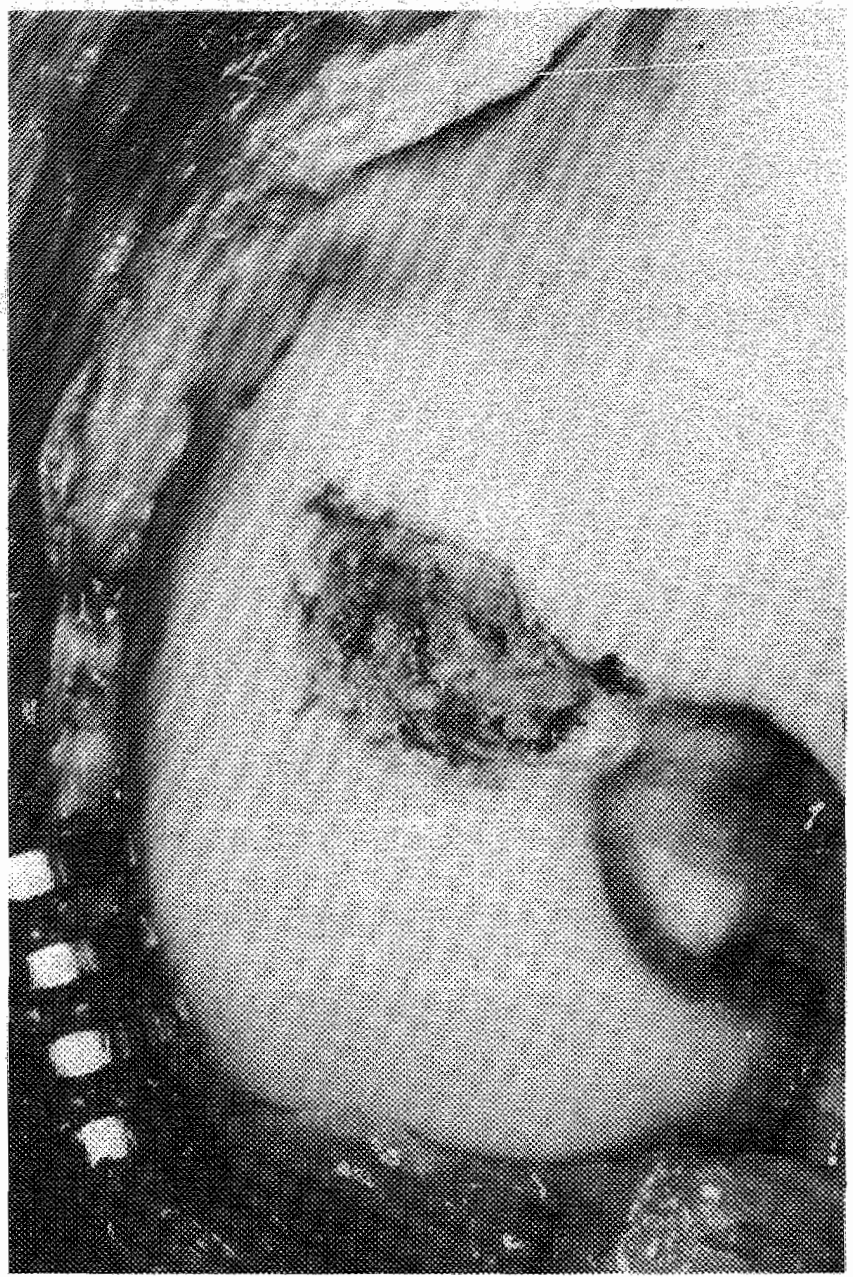

Figure $8.5 a$

An old osteochondritic lesion of the proximal, lateral part of the medial femoral condyle.

\section{B. Biopsy}

For a long time ethical considerations have prevented us from taking biopsies after apparently succesful transplantation of costal perichondrium and formation of normal looking cartilage. In the end we took biopsies from three grafts for the following reasons:

1. Macroscopical features are in no way a guarantee for the histological aspect. To plan further activities for the patient it seems essential to know whether the tissue formed is able to withstand greater forces. 


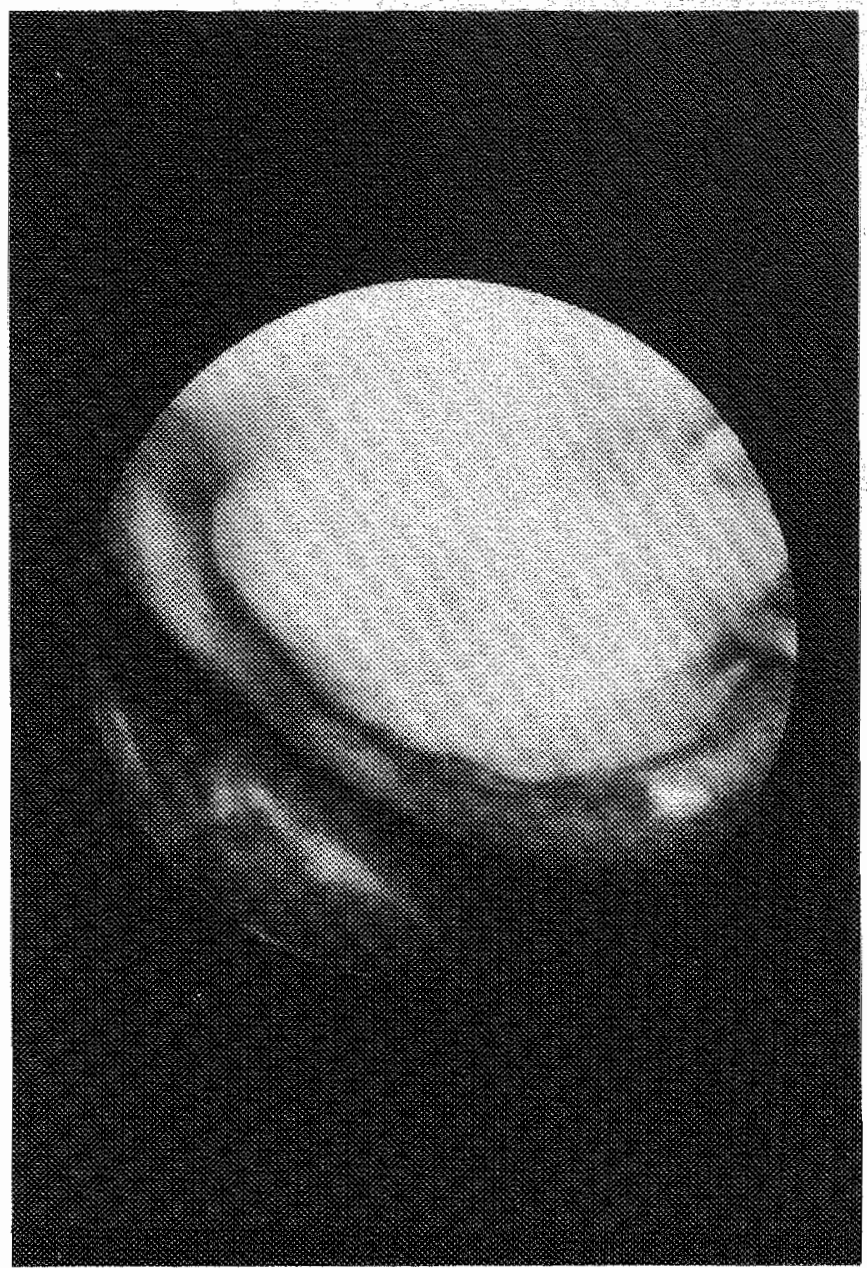

Figure 8.56

Arthroscopy of one year after perichondrial grafting: The neocartilage is elevated above the level of the joint surface.

2. A biopsy needle of $1.8 \mathrm{~mm}$ diameter was used, so the result is comparable with a Pridie-drilling in normal cartilage.

Macroscopically the biopsies formed a solid core of bone firmly attached to a thick layer of tissue resembling cartilage.

Biopsies were taken one year after grafting and kept in neutral formaline, decalcified, embedded in paraffin sectioned at $10 \mu \mathrm{m}$ and stained with haematoxyline-eosin, alcian Blue-PAS. The second biopsy was not decalcified, so that calcium staining according to Von Kossa was possible.

Examination of the histological picture of the tissue twice revealed a disrup 
Figure 8.6

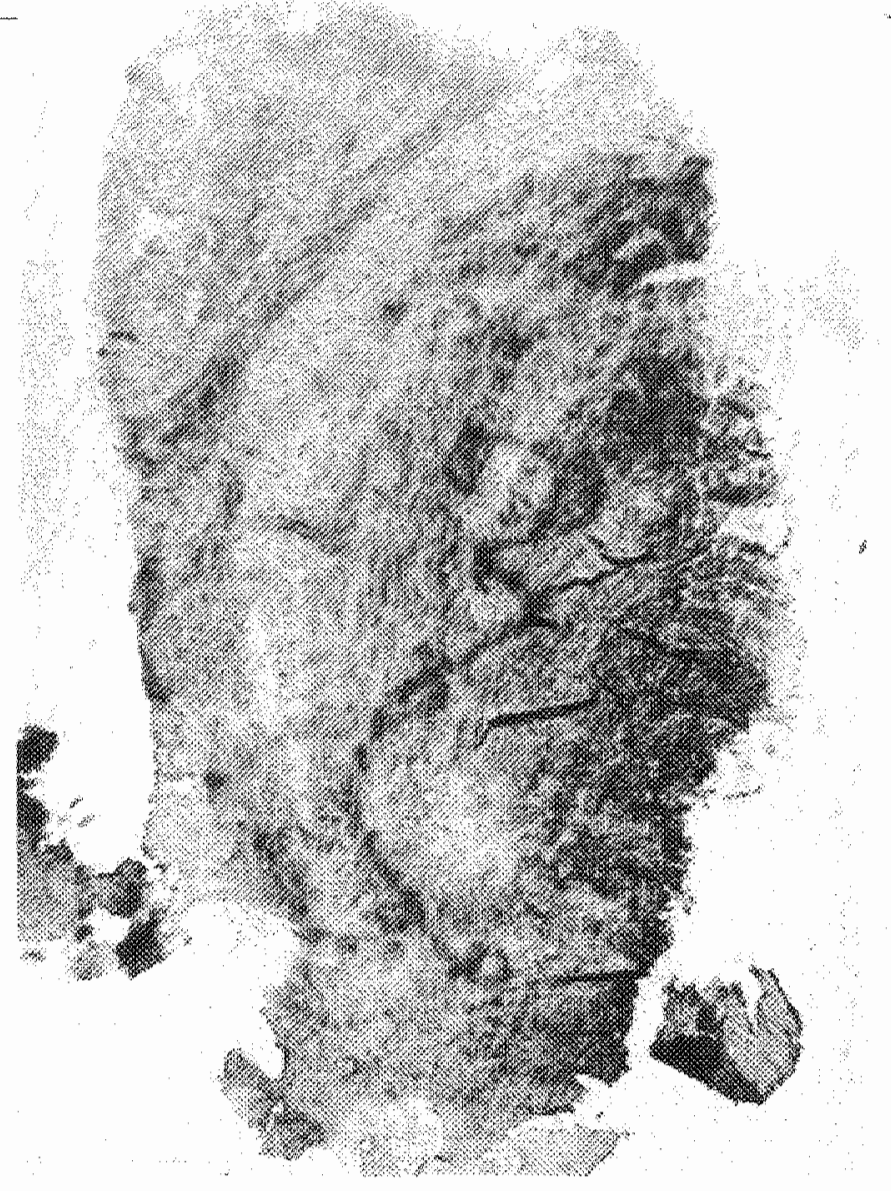

A biopsy taken from the tissue of Figure 8.56 ; thickness $312 \mu \mathrm{m}$. HE $\times 36$.

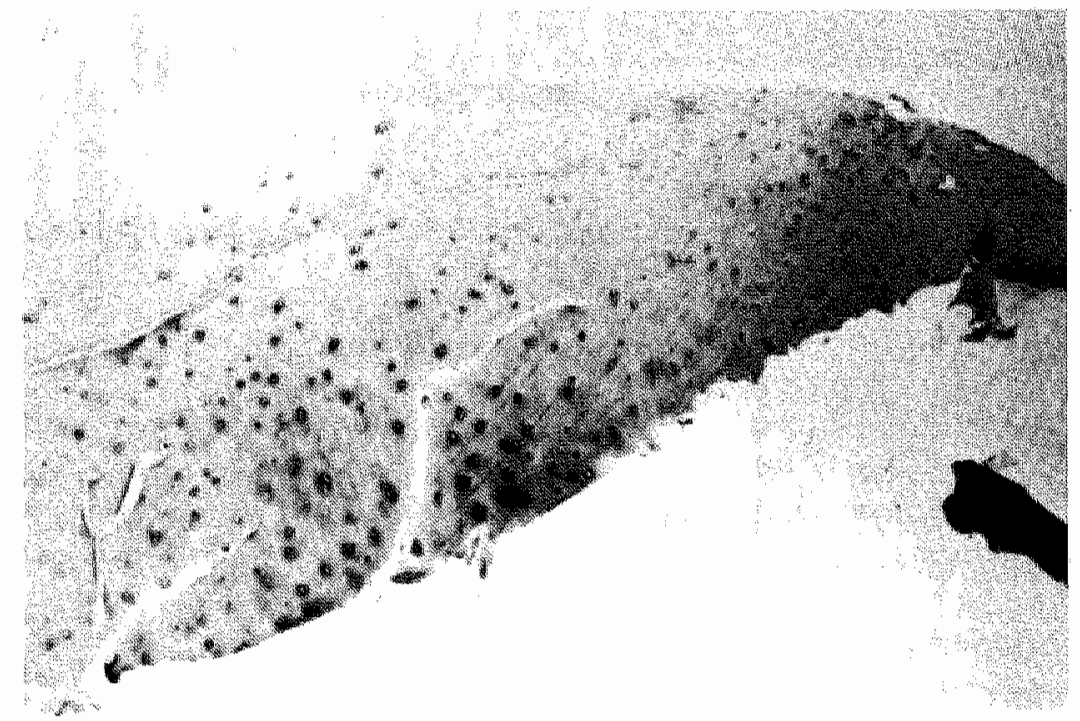

Figure 8.7

Low-power photomicrograph of a biopsy taken from the graft seen in Figure 8.4b. Normal articular cartilage is seen with chondrocytes located without clustering: thickness $152 \mu \mathrm{m}$. HE $\times 36$ 
Figure 8.8

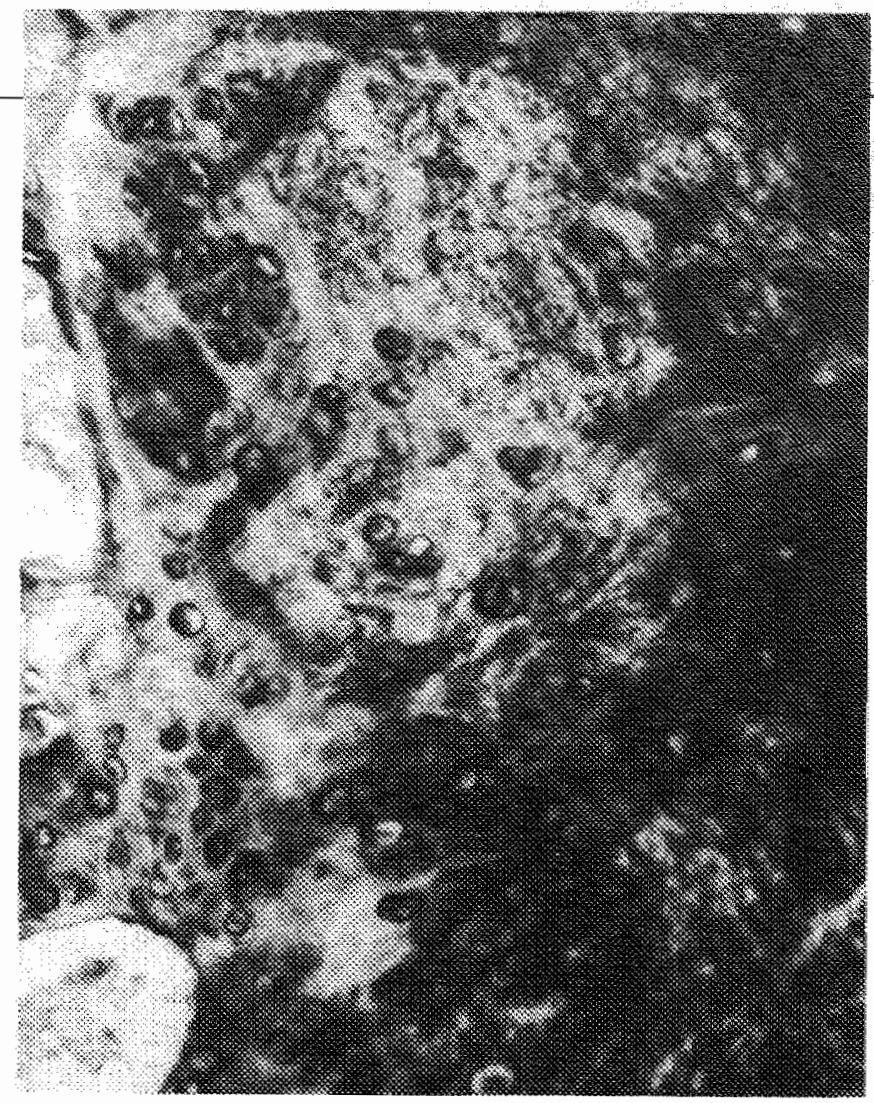

Histology of a biopsy taken from the graft at the edge of the medial facet of the patella, one year after perichondrial grafting. Normal articular cartilage is seen with a good bond between bone and cartilage. Alcian Blue PAS $\times 91$.

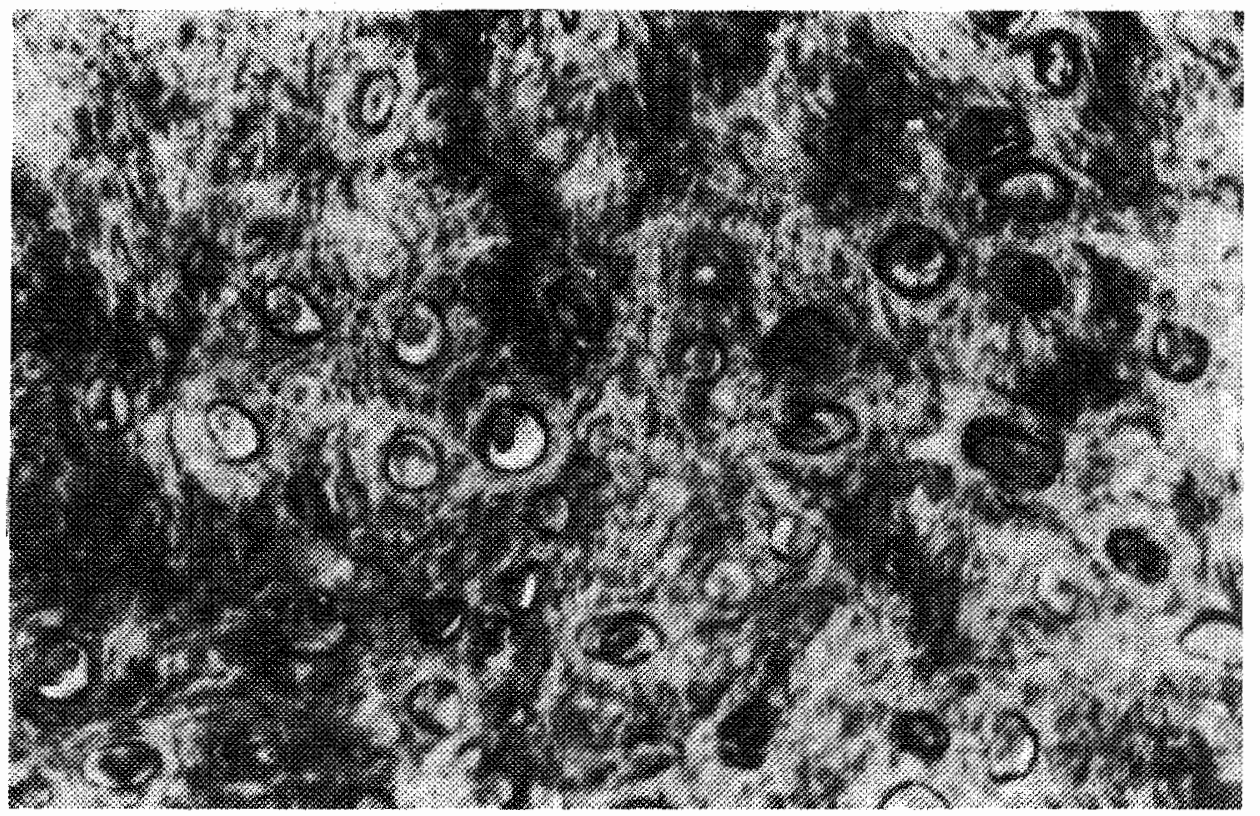

Figure 8.9

Detail of the cartilage formed after one year: magnification of Figure 8.6. Isolated chondrocytes with pericellular lacunae are located in a normally staining matrix. Alcian Blue $\times 360$. 
tion of cartilage and bone. In the third biopsy an uninterrupted contact was present between the two tissues.

The predominant tissue in the biopsies was cartilage (Figure 8.6, 8.7, 8.8,8.9 and 8.10 ).

The biopsy of figure 8.6 was taken from a graft located at the lateral, proximal part of the medial femoral condyle and has a measured thickness of $321 \mu \mathrm{m}$. It showed a longitudinal streak of fibrous tissue, which may be the transitional zone between the two pieces of perichondrium used in this case.

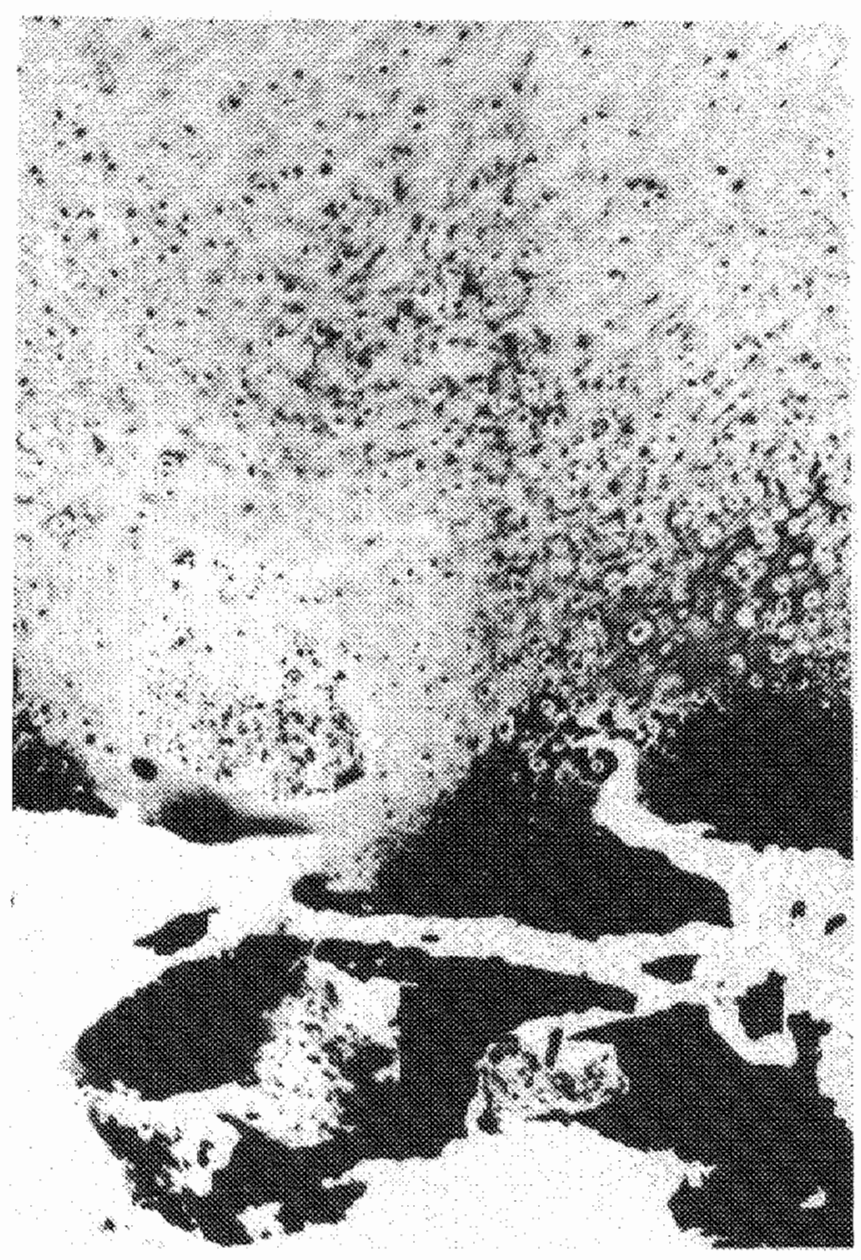

Figure 8.10

Calcium staining, black, is seen in the bone and in the basal laver of the cartilage. Von Kossa $\times 91$. 
The superficial layer mainly consisted of fibrocytes while the underlying tissue has all the characteristics of articular cartilage (Figure 8.9). No mitoses or clustering of cells were seen. In the alcian blue PAS a diffuse blue staining of the intercellular ground substance (matrix) was seen indcating the presence of acid mucopolysaccharides, exclusively produced by chondrocytes. In the higher magnification the shape of the cells was studied: normal looking chondrocytes with pericellular lacunae, the wall of which stained red with PAS (Figure 8.9). With the Von Kossa staining the subchondral bone stains black, whereas in the basal layer of the cartilage black staining of the intercellular substance was visible, suggesting the presence of calcium (Figure 8.10).

\section{Radiological examination}

One year after operation, X-rays in AP and lateral direction were taken of all knees as well as tangential views of the patella in $30^{\circ}$ of flexion. A density was seen at the level of the cartilage in 20 knees suggesting an increase of calcification of the cartilage layer (Figure 8.11).

In none of the $X$-rays taken after one year an increase of joint space narrowing, number of osteophytes, increase of subchondral bone density or cystes were observed. So radiological signs of progress of arthrosis were not visible.

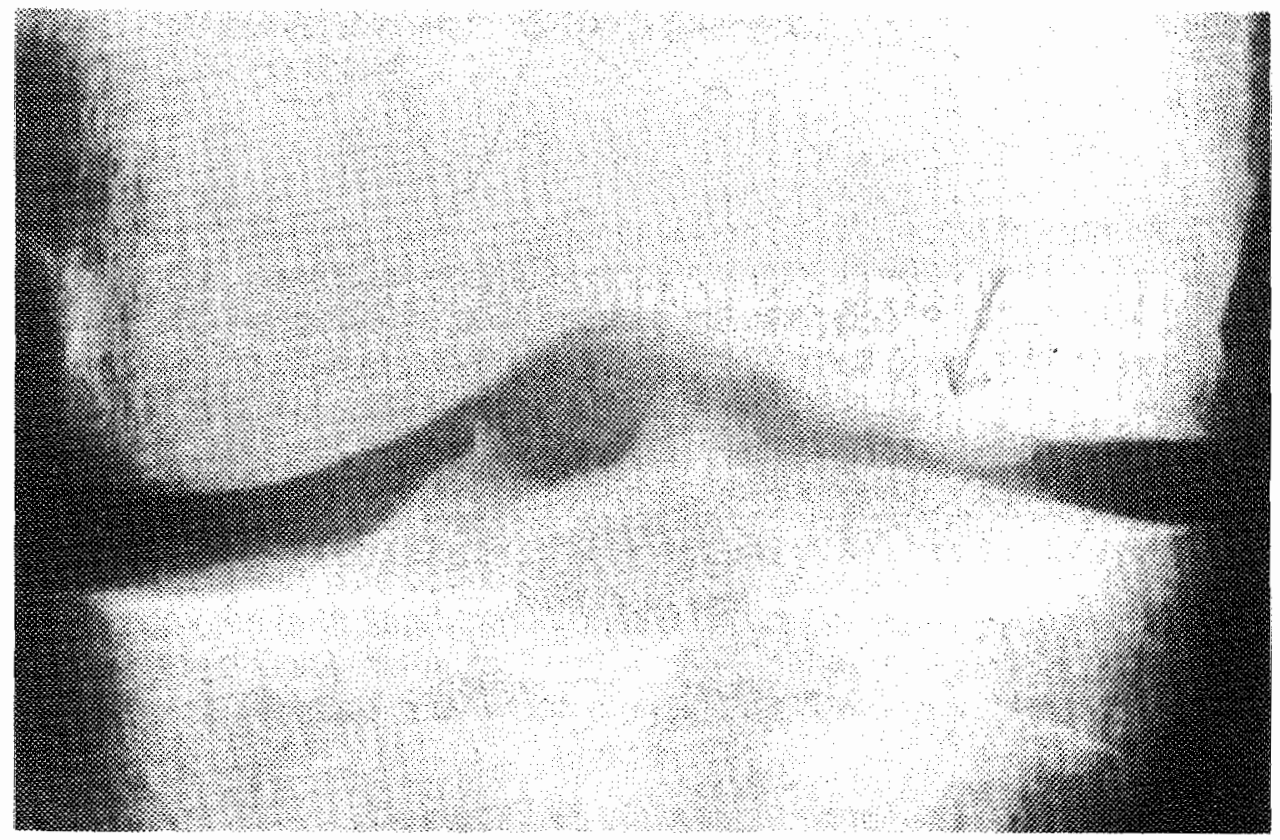

Figure 8.11

Roentgenogram of the knee in AP shows an increased density of the cartilage zone where the graft has been placed. 


\section{Knee score}

One year after operation all patients were questioned and examined and the follow-up sheet was completed. A summary of the most relevant symp toms and signs is given in Table 8.7. A comparison was made with the number of positive symptoms and signs before operation. Statistically significant alterations were established for starting pain, swelling, limitation of extension, locking, giving way, pain at night, pain in rest, pain in motion, hydrops and synovial swelling. Morning stifness, feeling of compression. crepitus, walking distance, quadriceps waisting, crepitus at examination and the use of aids did not change significantly compared with the situation before operation.

The mean postoperative kneescore was 89.9 (SD 9.9), range 58.5-100. The individual change in kneescore is elucidated in Table 8.3., the mean change in knee score in table 8.8. One year after operation all patients, but one, had a higher kneescore than before (Figure 8.12).

\section{CHANGE OF KNEE SCORE}

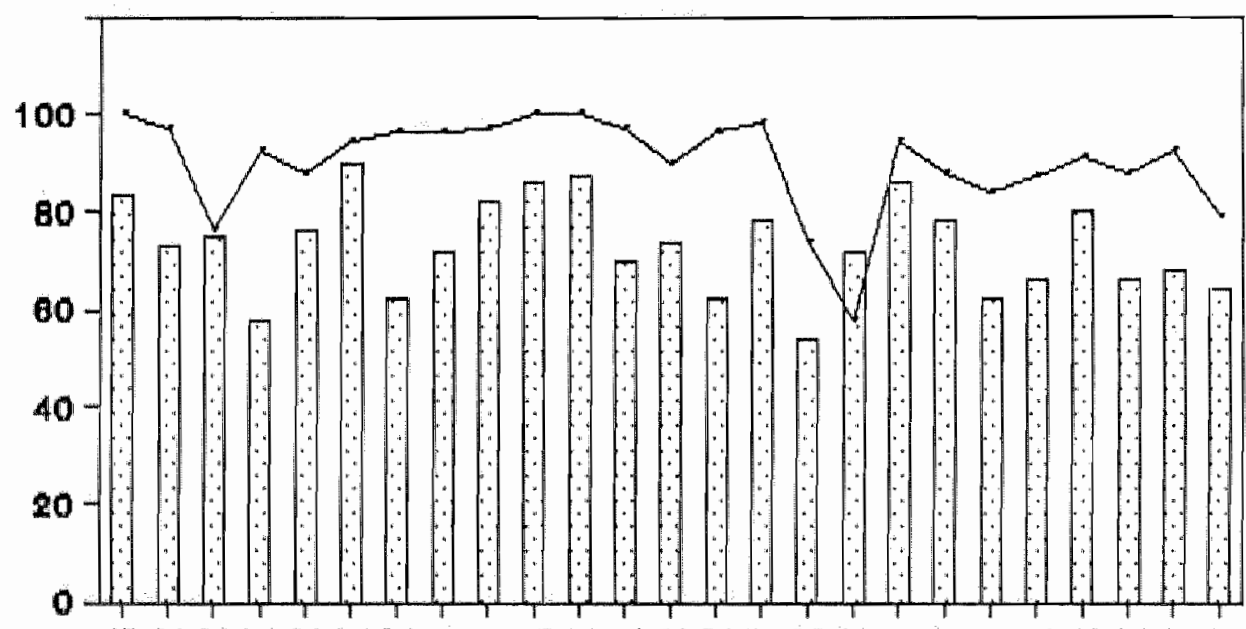

18212222222424262828293031313232333436414141444646 age of patlent

$\because$ proop $\rightarrow$ postop

Figure 8.12

Graphical presentation of the change in knee score before and one year after operation related to the age of the patient at the time of the operation. 


$\begin{array}{llll} & \text { Pre } & \text { Post } & P \\ \text { Kneescore } & 73(\text { SD 9) } & 90(\text { SD 10) } & <0.001^{*}\end{array}$

TABLE 8.8. Mean knee score analyzed before and one year after operation.

\section{* Paired T-test}

The mean change in knee score is 17 (SD 9), range -14.5 to 35 .

One year after operation 18 patients were completely free of symptoms: they resumed their previous work and sports activities. All these patients had localised cartilage defects without changes of the rest of the cartilage. According to Ranawats classification (1976) the results were as follows:

$\begin{array}{lrr}\text { Result } & \text { Pre } & \text { Post } \\ \text { Perfect } & 0 & 2 \\ \text { Excellent } & 3 & 18 \\ \text { Good } & 13 & 4 \\ \text { Fair } & 7 & 0 \\ \text { Poor } & 2 & 1\end{array}$

TABLE 8.9. Change of condition before and one year after operation, assessed with the knee disability sheet according to Ranawat (1976).

Perfect: 100 points; excellent: $85-100$ points; good: $70-84$ points; fair: $60-69$ points; poor $<60$ points.

Most patients changed from good to excellent $(n=10)$, some from fair to excellent $(n=5)$ and a minority from good to perfect $(n=2)$.

One patient changed from poor to good, one from poor to excellent and another one from fair to good. Two patients remained good and two remained excellent.

The two patients who scored excellent preoperatively complained about pain during working activities. In all three cases they were able to resume their work 4-5 months after the operation. In one patient arthroscopy was done at a previous time because of symptoms of locking and pain. At arthroscopy the graft appeared to have a flap at the side, interposing between the articular surfaces.

This part was resected, after which the patient became free of symptoms. 


$\begin{array}{llll} & \text { Pre } & \text { Post } & \text { P } \\ \text { Starting pain } & 14 & 3 & 0.01^{*} \\ \text { Morning stiffiness } & 14 & 9 & \text { NS * } \\ \text { Swelling } & 18 & 6 & 0.02 * \\ \text { Limitation of extension } & 8 & 1 & 0.04 * \\ \text { Locking } & 14 & 4 & 0.03 * \\ \text { Crepitus } & 21 & 15 & \mathrm{NS} * \\ \text { Feeling of compression } & 10 & 3 & \mathrm{NS} * \\ \text { Giving way } & 20 & 7 & 0.02 * \\ \text { Pain at rest } & \mathrm{M} 2.16 & \mathrm{M} 1.4 & 0.001^{* *} \\ \text { Pain at night } & \mathrm{M} 2.16 & \mathrm{M} 1.32 & <0.001^{* *} \\ \text { Pain in motion } & \mathrm{M} 3.4 & \mathrm{M} 1.6 & <0.001^{* *} \\ \text { Walking distance } & \mathrm{M} 3.56 & \mathrm{M} 3.84 & \mathrm{NS} * \\ & & & \\ \text { Quadriceps waisting } & 16 & 15 & \mathrm{NS} * \\ \text { Hydrops } & 10 & 3 & \mathrm{NS} * \\ \text { Synovial swelling } & 12 & 3 & 0.03 * \\ \text { Crepitation } & 11 & 17 & \mathrm{NS} * \\ \text { Aids } & 2 & 2 & \mathrm{NS} *\end{array}$

TABLE 8.7. Number of patients with symptoms and signs analyzed before and one year after operation.

* McNemar test

** Wilcoxon signed rank test

\section{Problem cases}

The results of the patients who improved hardly or not $(n=4)$ or got worse $(n=1)$ will be discussed in the following:

- A 24-year old woman had undergone several operations, including a Maquet procedure, for disabling chondromalacia patellae. Her knee score did not alter after perichondrial arthroplasty of the complete medial facet of the patella (75-75.7). At arthroscopy one year later the medial facet was covered with cartilage resembling tissue. A biopsy was taken, showing normal looking cartilage (Figure 8.8). However, the lateral facet seemed depressed and brownish discoloured and soft.

The knee function as a whole did not improve because of proceding deterioration of the lateral facet of the patella.

- A 35-year old man, a road constructing labourer, had a large defect of the 
lateral femoral condyle extending to the subchondral bone. Perichondrial arthroplasty of this defect did not reduce his complaints. Postoperatively he complained of giving way although no instability could be demonstrated and the anterior cruciate ligament seemed to be intact. At arthroscopy after operation the defect showed an unchanged crater defect. He is the only patient whose condition got worse: his knee score dropped from 72 to 58 .

- A 31-year old painter was treated for an old crater in the weight bearing part of the medial fernoral condyle and a degenerated cartilage spot at the medial facet of the patella. The former cartilage defect was caused by osteochondritis disssecans and had been drilled. Eight months after perichondrial grafting of both defects arthroscopy was performed: The patella defect was filled up with cartilage resembling tissue while a crater remained at the medial femoral condyle. No specific reason could be found why grafting failed in this case. The man could not resume his job as a painter and had to be reeducated to an office job.

- Since 6 years a 32-year old clerk had disabling pain and symptoms of locking and giving way due to a ruptured anterior cruciate ligament and a cartilage defect of the lateral femoral condyle. Before operation he used an orthosis in order to walk. The anterior cruciate ligament was reconstructed using the central part of the patella tendon and the cartilage defect was covered with a strip of costal perichondrium. One year after operation his knee score had gone up from 55 tot 75 . He walks without aids and has resumed his work. He still feels unable to perform strenuous activities and at examination a slight instability remained to be demonstrated.

- A 46-year old mechanic was treated for a cartilage defect of the medial femoral condyle. Postoperatively he developed algodystrophy with intense pain. Seven months after the operation a diagnostic arthroscopy was performed: The defect was completely filled up with tissue resembling articular cartilage, slightly elevated above the joint surface. One year after operation his knee score was 79 (preop. 64). He receives workers compensation and is not likely to resume his professional occupation in future.

\section{Long term results}

The first 14 patients were evaluated again after 17-32 months (mean 23.5 months). This was done to assess whether the condition of the graft and subsequently of the knee might deteriorate with time passing.

The mean knee score after this period of time was 86.6 (range 67-100) while after one year the knee score was 84.3 (range 75-100). No statistical difference in kneescores could be assessed (Paired T-test: NS). Three patients had a considerable lower kneescore than after one year: -A carpenter with severe chondrocalicinosis and degenerative changes in all three compartments of the knee. Roentgenograms showed osteophytes 
of the medial and lateral condyle and calcifications in joint lines.

-The 24-year old woman with chondromalacia of the patella of the which medial facet was grafted. At arthroscopy after one year, softening and brownish discoloration of the lateral facet was seen.

-A 46-year old man who developed algodystrophy of his leg after a succesfull perichondrial grafting of a defect of the medial femoral condyle. He got labourers compensation and did not resume his work. No radiological signs of arthrosis were seen after 16 months.

Those patients $(n=8)$ who had no complaints after one year had resumed their work and sports activities and did not notice any change in the condition of their knee from the first to the second year after operation.

Relation between the age of the patient and the result

It may be possible that with increasing age the chondrogenic capacity of perichondrium decreases, which may influence the result of perichondrial grafting of cartilage defects of the knee in a negative way. Therefore we studied the relation between the age of the patient at the time of operation and the knee score. With increasing age a decrease in kneescore was found before as as well as one year after operation. The result of the operation, ,measured as the difference in knee score, is not influenced by the age of the patient (Figure 8.12).

The Spearman rank correlation coefficient for this relation is 0.0172 (NS). For the relation age and postoperative kneescore the Spearman rank correlation coefficient is -0.2656 . From this it may be concluded that in our patient group with perichondrial arthroplasty of the knee the result of the procedure was not related to the patients age.

Relation between preoperative delay and result

Long existing cartilage lesions may affect the condition of the rest of the cartilage of the same joint, by causing a chronic synovitis and subsequently a diminished muscular control and degeneration of the rest of the cartilage. In our group the majority of patients had complaints for a longer period of time (Mean 37 months, range one month to twelve years). The relation between the preoperative delay and the change in knee score was analyzed and graphically presented (Figure 8.13).

The Spearman rank correlation coefficient is -0.3822 . When a trend line is constructed from the individual changes in knee score, a decrease is seen with increasing preoperative delay (Figure 8.14). 


\section{CHANGE OF KNEE SCORE related to preop delay}

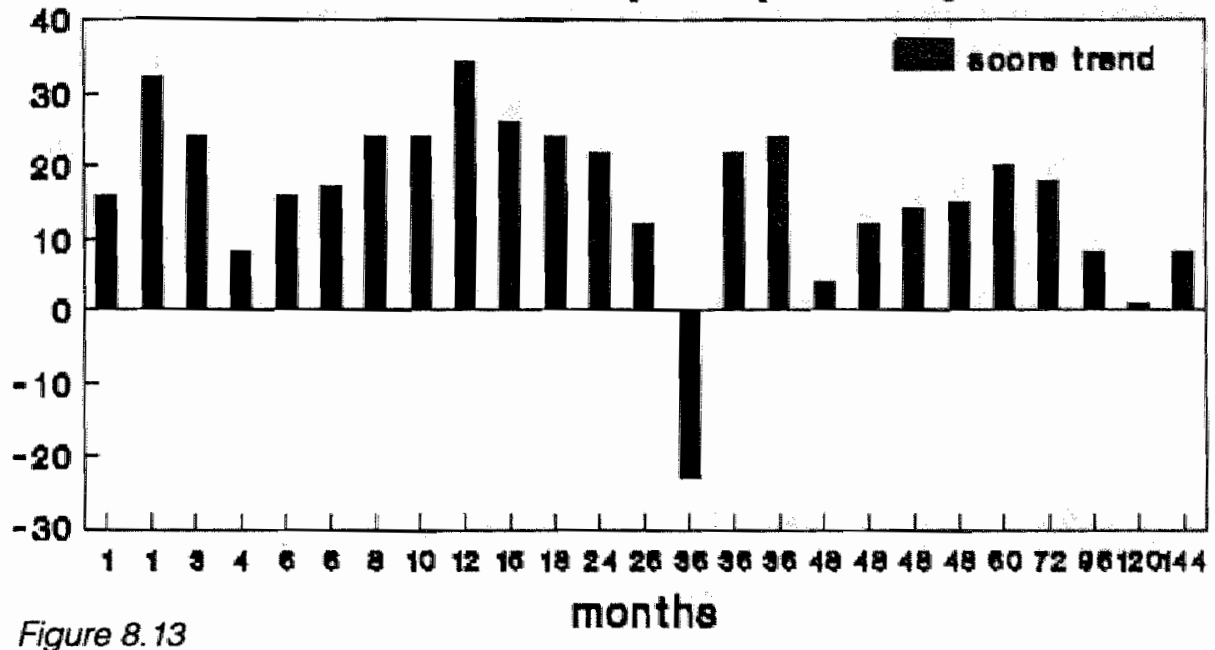

Graphical presentation of the change in knee score related to the time between the onset of the symptoms and the operation ie.preoperative delay.

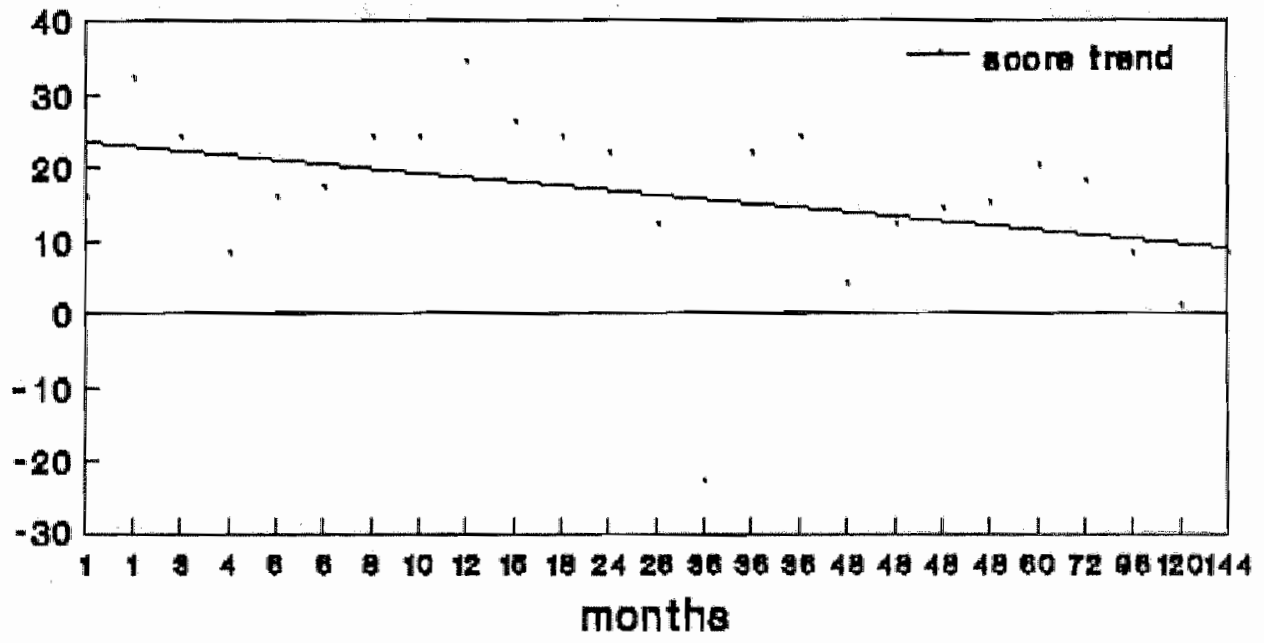

Figure 8.14

Graphical presentation of the trend in result related to the preoperative delay. There is a slight decrease in result with increasing preoperative delay.

The result of treatment of long existing cartilage lesions by perichondrial arthroplasty in our group of patients is worse than the results of treatment of relative recent cartilage lesions. However, we studied a relative small group of patients, so it is too early to conclude that all symptomatic cartilage lesions must be treated as soon as possible to get better results. 
Relation between graft location and result

The formation of cartilage depends on movement and loading, as was discussed in chapter two. With this knowledge in mind one may wonder whether cartilage formation out of a perichondrial graft from the rib gives similar results on different locations in the knee. We therefore analyzed the relation between the mean change of knee score and the graft location and presented this graphically (Figure 8.15).

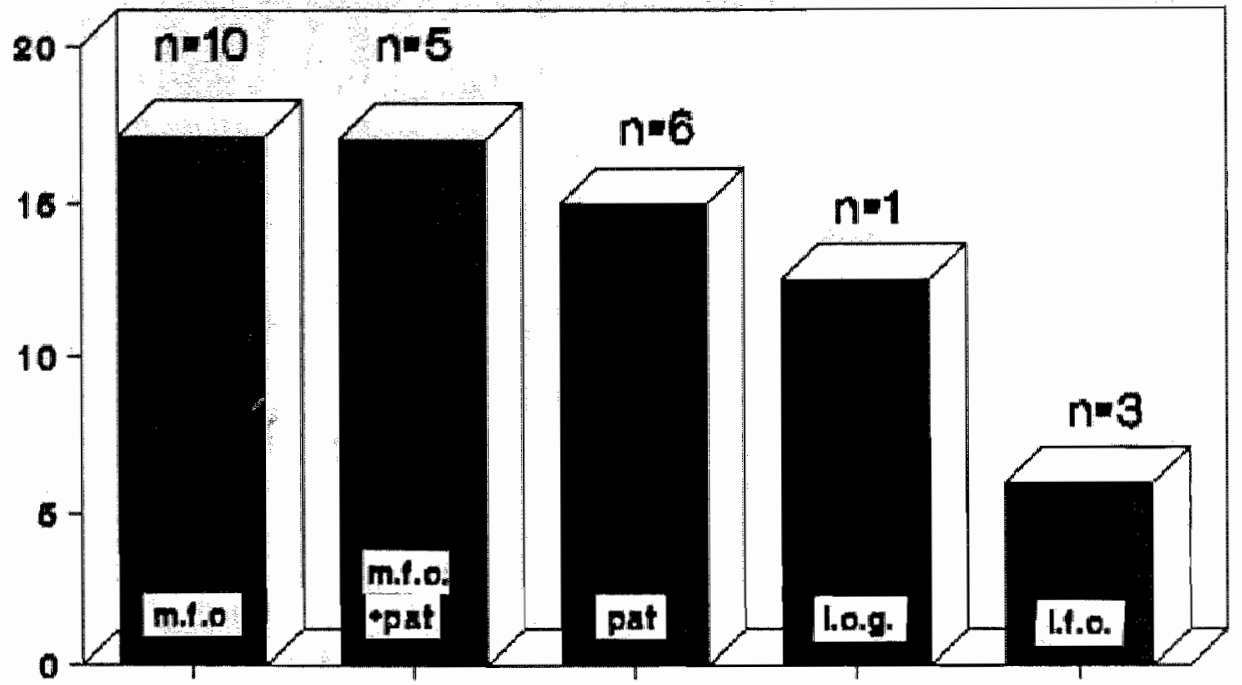

Figure 8.15

Graphical presentation of the mean change in knee score in relation to the graft location. m. f.c. = medial femoral condyle; pat $=$ patella; i.c.g. = intercondylar groove; I. f.c. = lateral femoral condyle.

No significant difference in change of knee score is seen between the grafts located on the medial femoral condyle, , medial femoral condyle plus patella, patella alone, lateral femoral condyle and intercondylar groove (Kruskall-Wallis test statistics $=2.96$. Level of significance $=0.5650$ ).

Biopsies were taken from the medial femoral condyle $(n=2)$ as well as from the patella $(n=1)$. In all three cases histologically articular cartilage was seen, with varying thickness and locally increased calcification concentration. It may be concluded that the formation of cartilage out of a perichondrial graft is not influenced by the location of grafting.

\subsection{Conclusions and discussion}

In this clinical prospective study 25 patients with a symptomatic articular cartilage defect of the knee, were treated by grafting the defect with an autologous piece of perichondrium taken from the rib.

The most relevant preoperative symptoms such as pain in rest and in motion, swelling, locking and giving way changed considerably and at a 
statistically significant level $(p<0.01-0.001)$. The preoperative knee score (range 0-100) changed from a mean of 73 before to a mean of 90 one year after operation $(p<0.001) .80 \%$ Of the 25 patients became free of symptoms; in one patient the clinical condition got worse.

Radiological signs of a beginning arthrosis, i.e. small osteophytes, in 6 patients (mean knee score after one year 88 )are not a negative predictive value in the outcome of our patients (mean postoperative knee score 90 ). Therefore it may be concluded that with perichondrial grafting of cartilage defects of the knee a great improvement can be achieved in the clinical condition of the patients involved. Apart from the case study of Hvid and Andersen (1981) these are the first results of perichondrial arthroplasty of the knee ever published. Therefore it is not possible to compare the results with other studies.

Long term results still have to be established. More definite conclusions about the durability of the newly formed tissue can only be drawn after longer follow up studies with larger groups of patients.

No relation between the result and the age of the patient was found as was suggested by Seradge et al. (1984), who grafted metacarpo- and interphalangeal joints in the hand. They concluded that over the age of 40 the results became worse and that perichondrial arthroplasty is not indicated to restore destroyed joints. In the cases we studied the change in knee score was comparable for younger and older patients( below the age of 47). Fixation of the perichondrial graft with fibrin glue was secure and adequate when combined with immobilization of the joint for two weeks. The same results were reported by Braun et al. (1982) who fixed chondral fragments with fibrin glue and applied an additional plaster for two weeks.

Continuous passive motion (C.P.M.) is the most favourable condition for the regeneration of articular cartilage (Salter et al. 1980, O'Driscoll et al.1988). Therefore the affected knee joint is submitted to this stimulus by placing the leg on a motor unit for two weeks, after the plaster has been removed.

Motion of the knee is continued for a minimum of 20 hours a day. In this way a favourable situation is created for the graft to develop to articular cartilage. It is difficult to say whether the final result is influenced by the two weeks of CPM. A comparative clinical study of patients with and without CPM after operation will answer this question.

Weight bearing was not allowed until three months after the operation. When a perichondrial graft was placed in the patello- femoral joint flexion of the knee is restricted to $30^{\circ}$ on the motor unit. In this case a hinged cast was applied before the patient was mobilized. Thus it was prevented that major forces damage the newly formed tissue.

In the first few months after operation the superficial layer of the graft is soft and can easily be damaged. Weight bearing may give peak loading of the graft and may damage it. The after treatment given in our group of patients reduced this possibility considerably.

Hvid (1981) reported a case history of traumatic chondromalacia. The 
defect was grafted with a piece of perichondrium and fixed with transfixing sutures. Full weight bearing was allowed after two weeks. One and a half year later tissue resembling cartilage had developed without damage of the joint surface. In our patient group the perichondrial graft developed to articular cartilage after an initial period of low pressure. Whether this protection of the graft is an absolute necessity has still to be established.

In 2 of the 30 recipient sites no regenerated tissue was seen at arthroscopy. No special reason could be pointed out as to why this occurred in these particular patients or graft locations.

Follow up arthroscopy was performed from 3 to 12 months after operation. In the first few months after operation a slightly elevated tissue was seen, resembling articular cartilage. Graft locations in the weight bearing area of the medial femoral condyle were more at level with the surrounding cartilage after one year than those in low friction areas and grafted places of old osteochondritic lesions, previously drilled. The mean change in knee score of patients with graft locations of medial femoral condyle, patella or medial femoral condyle plus patella showed no significant difference.

Most grafted defects had an intact subchondral bone plate which was only scraped until point haemorrhages became visible. In 7 cases the graft was placed onto the cancellous bone which was opened by previous drilling. long existing degenerative cartilage defects or osteochondritis dissecans. No difference was found in cartilage formation or change in knee score in relation to the presence or absence of the subchondral bone plate. This is in contradiction with the suggestion of Engkvist (1980), who concluded that cartilage regeneration from perichondrium can only occur when the perichondrium is placed onto cancellous bone.

Roentgenograms of the knees taken one year after perichondrial arthroplasty showed a density in the grafted place indicating an increased mineralization of the cartilage. Calcium staining techniques of a biopsy taken from the graft also revealed an increased uptake of calcium of the basal layer of the cartilage. This finding agrees with the results of Plenk and PassI (1981) who found an increased mineralization of the basal layer of the cartilage after fixing chondral fragments with fibrin glue into the knees of sheep. It must be assumed that the mineralization of the basal layer of the newly formed cartilage in the grafts of our patient group is also increased compared with normal cartilage. What intpact this will have on the viscoelastical qualities of the cartilage and on its durability is still unclear. Up to now it seems that the new cartilage can withstand major forces as applied to it in contact sports.

Long term results in larger groups of patients will give a more definite judgement of the cartilage, generated from a perichondrial graft of the rib. The results of this study justify the following conclusion: Grafting of articular cartilage lesions of the knee with an autologous perichondrial graft results in the formation of cartilage and gives subsequent clinical improvement to the patient. 


\section{SUMMARY}

Cartilage defects of the knee are often symptomatic and have little tendency to spontaneous healing. In chapter one the incidence and current methods of treatment of cartilage lesions are discussed. It is concluded that the results are often not satisfactory especially for the localised lesions in young patients. The main reason for this is that no surgical technique can fill the defect with a new layer of hyaline cartilage.

Perichondrium is the basic structure responsible for the formation of cartilage during the embryonic period. Animal studies have indicated that cartilage generated from perichondrium has the same qualities as normal articular cartilage. Clinically perichondrium has been used to restore small arthrotic joints of the hand with good results. For the use of a perichondrial graft in larger joints like the knee the main problem is graft fixation and the role of the subchondral bone plate in the regeneration of cartilage.

After the problem description a new treatment for cartilage lesions of the knee is suggested. The purpose of this thesis is formulated:

To assess the chondrogenic capacity of perichondrium in the rabbit knee. To establish the cartilage generating capacity of costal perichondrium of the adult man.

To test the usefulness of fibrin glue in fixing a perichondrial graft to a cartilage defect of the knee.

To describe the change in clinical condition of patients treated with a perichondrial graft of the knee.

To observe and to describe this graft arthroscopically and histologically. In chapter two the normal structure, composition and qualities of articular cartilage are summarized.

In chapter three a review of the literature is given on the subject of the reaction of articular cartilage to damage, its etiology and its natural course. Different types of lesions and locations are mentioned. Factors influencing the repair reaction are discussed.

In chapter four the chondrogenic capacity of perichondrium is elucidated.

The qualities of the newly formed cartilage are described referring to animal experiments and clinical application. It is suggested to use fibrin glue as an adhesive in order to restore cartilage defects in larger joints like the knee 
with a perichondrial graft.

In chapter five the composition and mode of action of fibrin glue is discussed. Its non-toxicity and biodegradability make fibrin glue suitable for the fixation of a perichondrial graft. These qualities outline the initial low adhesive strength. This was confirmed in animal experiments and clinical studies in which (osteo)chondral fragments succesfully were fixed with fibrin glue. In chapter six the animal experiments are described. it was confirmed that costal perichondrium when placed in a cartilage defect of the knee forms articular cartilage. The non grafted control defect of the other knee showed the formation of fibrous or fibrocartilaginous tissue. Tissucol, a fibrin glue was used to fix the graft to the subchondral bone. This proved to be an adequate method when combined with an external fixation device and did not show any adverse reactions.

Long term results in adult rabbits gave similar results.

In chapter seven in vitro culture of human adult costal perichondrium was done to test the chondrogenic capacity of this structure in the adult man. After 7 and 10 days the thickness of the layer had increased considerably and the chondrocytes generated out of the perichondrial explant had formed intensely staining matrix, indicating the formation of glycosaminoglycans. It was concluded that human adult perichondrium has the ability to produce cartilage.

In chapter eight a prospective clinical study is presented in which the effect of perichondrial grafting of a cartilage defect of the knee is evaluated. This is done by means of assessing changes in knee score, arthroscopy, biopsies and radiological examination. The mean knee score changed from 73 to $90(p<0.001)$. The surgical procedure is described as well as the mode of postoperative treatment: 2 weeks P.O.P. 2 weeks CPM and postoperatively 3 months without weight bearing.

Biopsies were taken from three grafts after one year: all showed tissue closely resembling articular cartilage. Calcium staining is present in the basal layer.

In a majority of the cases roentgengrams after one year showed a density in the basal layer of the graft suggesting an increased calcium uptake. An increase in the number of radiological signs of gonarthrosis was not seen. Finally the results are discussed and conclusions are drawn. Perichondrial grafting of a cartilage defect of the knee results in the formation of a tissue, closely resembling articular cartilage. This is a considerable improvement compared to other techniques used at the moment which result in the formation of fibrous or fibrocartilaginous tissue. The clinical results are excellent or perfect in 80 percent of the patients. Preoperative delay, age of the patient at the time of the operation and graft location seem to play a minor role in the final result of the procedure. The knee score of the first ten patients hardly changed between the first and second year after the operation. This suggests that at longer term good results may be expected, even when maximal loading of the knee is permitted. 


\section{SAMENVATTING}

Kraakbeenlesies van de knle geven vaak aanleiding tot klachten en hebben slechts een zeer geringe neiging tot spontaan herstel. In hoofdstuk eén worden het voorkomen en de huidige experimentele en klinische behandelingsmethoden van gewrichtskraakbeendefecten van de knie besproken. Samengevat kan men zeggen dat de behandeling van gelokaliseerde defecten bij met name jonge patienten vaak teleurstellend is. De belangrijkste reden hiervoor is dat met geen van de huidige chirurgische technieken het defect opgevuld kan worden met normaal gewrichtskraakbeen. Perichondrium is de structuur die tijdens de embryonale periode verantwoordelijk is voor appositionele groei van kraakbeen. Dierstudies hebben uitgewezen dat kraakbeen gevormd door perichondrium dezelfde eigenschappen bezit als normaal gewrichtskraakbeen. In de kliniek is perichondrium met goed resultaat gebruikt om de arthrotische gewrichtjes van de hand te behandelen. Wil men kraakbeenlesies van grotere gewrichten zoals de knie met perichondrium gaan behandelen dan is er het probleem van de fixatie van het transplantaat. Omdat bij zuivere kraakbeenlesies de onderliggende botlaag intact is dient nader te worden bekeken wat de rol is van de subchondrale botplaat op de nieuwvorming van kraakbeen. Tevens dient er duidelijkheid te komen over de chondrogene eigenschappen van perichondrium van volwassenen.

Nadat de probleemstelling is geformuleerd worden de doeistellingen van dit proefschrift samengevat:

Aantonen dat ribperichondrium een kraakbeendefect in de konijneknie kan herstellen en vergelijken met het resultaat van een niet behandeld defect. Het uittesten van de effectiviteit van fibrinelijm bij het bevestigen van het perichondrium transplantaat.

Het beschrijven en evalueren van de patienten met een kraakbeeniesie van de knie, die behandeld worden met een perichondrium transplantaat. Het perichondrium transplantaat wordt arthroscopisch gecontroleerd en histologisch onderzocht.

In hoofdstuk twee worden de normale structuur, samenstelling en eigenschappen van gewrichtskraakbeen samengevat.

Hoofstuk drie geeft een overzicht van de literatuur betreffende de reactie 
van gewrichtskraakbeen op beschadiging, de oorzaken hiervan en het natuurijke beloop. Factoren die de herstelreactie van het kraakbeen kunnen bernvloeden worden besproken.

De kraakbeenvormende eigenschappen van perichondrium worden toegelicht in hoofstuk vier. De eigenschappen van het nieuwgevormde kraakbeen worden beschreven met verwijzing naar dierexperimenten en klinische toepassing. Om kraakbeendefecten in grotere gewrichten te kunnen bedekken is een lijmstof nodig. Fibrinelijm lijkt hiervoor het meest geschikt. In hoofstuk vijf wordt de samenstelling en werkingswijze van fibrinelijm besproken. Zijn niet-toxische en biologische afbreekbare eigenschappen lijken fibrinelijm zeer geschikt te maken om een perichondrium transplantaat te fixeren. Deze beide eigenschappen bleken belangrijker dan de kleefsterkte die aanvankelijk nogal laag is. Dit werd aangetoond in dierexperimenten en klinische studies waarbij (osteo)chondraal lesies van de knie met succes met fibrinelijm werden gefixeerd.

Het dierexperimenteel onderzoek wordt gerapporteerd in hoofdstuk zes. De nieuwvorming van gewrichtskraakbeen wordt beschreven nadat een stukje ribperichondrium in een kraakbeendefect van de knie is geplaatst. Na een jaar wordt een verhoogd calciumgehalte aangetoond van de basale laag van het kraakbeen. In het controle defect zien we slechts de vorming van fibreus en fibrocartilagineus weefsel. Tissucol(R), een humane fibrinelijm werd gebruikt om het transplantaat te bevestigen op de subchondrale botplaat. Dit blijkt een adequate fixatietechniek mits gecombineerd met een fixateur externe. Er werden geen nadelige gevolgen van de lijm waargenomen. Ook na éen jaar en bij volgroeide konijnen werd de vorming gezien van normaal gewrichtskraakbeen. Het intact laten van de subchondrale botplaat bleek geen negatieve invloed te hebben op het resultaat. In een weefselkweek van ribperichondrium van volwassen mensen werd de vorming van weefsel waargenomen met alle eigenschappen van gewrichtskraakbeen. De techniek en het resultaat hiervan wordt beschreven in hoofdstuk zeven. Geconcludeerd wordt dat perichondrium van volwassen mensen kraakbeenvormende eigenschappen bezit.

In hoofstuk acht wordt een prospectieve klinische studie gepresenteerd. Bij 25 patienten werd een kraakbeendefect van de knie bedekt met een autoloog perichondrium transplantaat van een der onderste ribben. De operatie techniek wordt besproken alsook de nabehandeling: twee weken een dorsale gipsspalk, twee weken CPM en in totaal drie maanden onbelast. Het resultaat van de ingreep wordt na een jaar geevvalueerd met behulp van een kniescore, arthroscopie "biopsieen en röntgenonderzoek.

De gemiddelde kniescore veranderde van 73 tot $90(p<0.001)$. In 27 van de 30 transplantaten wordt bij arthroscopie een volledige opvulling gezien van het kraakbeendefect met op kraakbeen gelijkend weefsel. In een aantal gevallen wordt, met name in de eerste maanden na de operatie, gezien dat het nieuwgevormde weefsel verheven is boven het gewrichtsvlak. Drie maal wordt een biopt genomen: in alle drie gevallen wordt weefsel gezien met 
grote overeenkomsten met gewrichtskraakbeen. Met een kalkkleuring wordt een verhoogde opname gezien van calcium in de basale laag.

Rontgenopnames van de knie, genomen één jaar na de operatie, vertonen in een meerderheid van de gevallen een densiteit in het kraakbeenniveau ter plaatse van het transplantaat. Dit suggereert een verhoogde calciumopname ter plaatse. In geen van de opnames wordt een toename gezien van tekenen van arthrosis.

Tenslotte worden er conclusies getrokken en de resultaten besproken. Wanneer een kraakbeendefect van de knie bedekt wordt met een perichondriumtransplantaat vormt zich weefsel dat grote gelijkenis vertoont met gewrichtskraakbeen. Dit op zich moet beschouwd worden als een grote verbetering van de huidige behandelingsmethoden waarbij zich hetzi] fibreus hetzij fibrocartilaginair weefsel vormt. De klinische verbetering. gemeten met de kniescore, is dusdanig dat 80 procent van de patienten vrijwel klachtenvrij wordt. De leeftijd van de patient ten tijde van de operatie, indien beneden 47 jaar, lijkt niet van invloed op het resultaat evenmin als de tijd dat de klachten reeds bestaan ten tijde van de operatie. Bij de eerste tien patienten blijkt twee jaar na de operatie de kniescore nauwelijks veranderd t.o.v. een jaar tevoren. Dit is mogelijk een aanwijzing dat het nieuwgevormde kraakbeen zich ook op wat langere termijn handhaaft, ook bij patienten die maximale eisen stellen aan hun kniegewricht. 


\section{REFERENCE LIST}

-Amiel D, Coutts RD, Harwood FL, Ishizue KK and Kleiner JB.

The chondrogenesis of rib perichondrial grafts for the repair of full- thickness articular cartilage defects in a rabbit model: A one year postoperative assessment. Connective Tissue Res 1988;18:27-39.

-Amiel D, Coutts RD, Abel M, Stewart W, Harwoord F and Akeson WH. Ribperichondrial grafts for the repair of full-thickness articular cartilage defects. A morphological and biochemical study in rabbits.

J Bone Joint Surg 1985;67-A(6):911-20.

-Amiel D, Harwood FL, Abel MF and Akeson WH. Collagen types in neocartilage tissue resulting from rib perichondrial graft in an articular cartilage defect- a rapid semi-quantative methodology. Collagen Rel Res 1985;5:33747.

-Archalensky: Centralblatt für die Medizinische Wissenschaften 1868. Uber die Regeneration des hyalinen Knorpels.

-Basset CAL. Current concepts of bone formation. J Bone J Surg 1962;44A:1217-44.

-Bauer $M$ and Jackson RW. Chondral lesions of the femoral condyles: A system of arthroscopic classification. Arthroscopy 1988;4(2):97-102.

-Bennet GA, Bauer W and Maddock SJ.

A study of the repair of articular cartilage and the reaction of normal joints of adult dogs to surgically created defects of articular cartilage: "joint mice" and patella displacement. Am J Path 1932;8:499-524.

-Bentley G and Greer RB. Homotransplantation of isolated epiphyseal and articular cartilage chondrocytes into joint surfaces of rabbits. Nature $1971 ; 230: 385-8$. 
-Bentley G, Dowd G and Orth MCh. Current concepts of etiology and treatment of chondromalacia patellae. Clin Orthop Rel Res 1983:189:20928.

-Benum P. Autogenous transplantation of apophyseal cartilage to osteochondral defects of joints. Acta Orthop Scand 1974;suppl.156.

-Bernett P, Pfister A, Sauer W and Erhart W. Klebung von Knorpelfragmente in Fibrinekleber in Orthopadie und Traumatologie; Ed. Cotta und Braun p. 145-50. Georg Thieme Verlag Stuttgart New-York 1982.

-Bohler N und Gaudernak T. Fibrineklebung osteochondraler Frakturen, in Fibrinklebung p.189-92. Springer Verlag Berlin Heidelberg New York Tokyo 1984.

-Braun von F, Holle J, Knapp W, Kovac W. Passl R und Spăngler HP. Immunologische und histologische Untersuchungen der Gewebeklebung mit heterologen hochconcentrierten Fibrinogen. Wien Klin Wschr $1975 ; 87: 815-9$.

-Braun A, Schumacher G und Heine WD. Fibrineklebung zur Replantation osteocartilaginarer Fragmente am Kniegelenk Kaninchens. Hefte zur Unfallheilkunde 1979;138:294-297.

-Braun A, Schumacher G und Heine WD. Fibrineklebung osteochondraler Fragmente im Tierexperiment. In: Fibrinekleber in Orthopadie und Traumatologie. Herausgegeben von H. Cotta und A. Braun p.110-124. Georg Thieme Verlag Stuttgart New York 1982.

-Brent B and Ott R. Perichondro-cutaneous graft. Plast Reconstr Surg $1978 ; 62: 1-14$

-Bulstra SK, Buurman WA, Walenkamp GHIM and Van der Linden AJ. Metabolic Characteristics of in vitro cultured chondrocytes in relation to the histopathological grade of osteoarthritis. Clin Orthop Rel Res 1989; 242:294-302.

-Burck $\mathrm{HC}$. Histologische Technik. Georg Thieme Verlag Stuttgart New York 1981.

-Calandruccio RA and Gilmer WS. Proliferation, regeneration and repair of articular cartilage of immature animals. J Bone Joint Surg 1962;44-A:43155. 
-Campbell CJ. The healing of cartilgae defects. Clin Orthop Rel Res 1969;64:45-63.

-Carison $\mathrm{H}$. Reactions of rabbit patellary cartilage following operative defects. Acta Orthop Scand 1957;Suppl.28:1-104.

-Chrisman OD. The effect of growth hormone on esthablished cartilage lesions. Clin Orthop 1975; 107:232-8.

-Claes L, Burri C, Helbing G and Lehner E. Biomechanische Untersuchungen zur Festigkeit verschiedener Knorpelklebungen. Helv.Chir.Acta 1981;48:11.

-Clark ER and Clark EL. Microscopic observations on new formation of cartilage and bone in the living mammal. The Am J of Anat 1942; vol 7,no 2:167-200.

-Convery FR, Akeson WH and Keown GH. The repair of large osteochondral defects. An experimental study in horses. Clin Orthop 1972;82:253-62.

-Coutts RD, Amiel D, Woo S-L-Y, Woo Y-K and Alieson WHO. Technical aspects of perichondrial grafting in the rabbit. Eur Surg Res 1984;16:322-8.

-Czitrom AA, Langer $F$, Mckee $N$ and Gross AE. Bone and cartilage allotransplantation. Clin Orthop Rel Res 1986;208:141-5.

-Davies DV. Properties of synovial fluid. Proc.Instn mech Engrs 1967;181(3J):2509.

-Dehaven KE. Diagnosis of acute knee injuries with hemartrosis. Am J Sports Med 1980; Vol 8(1):9-14.

-Dekel S and Weismann SL. Joint changes after overuse and peak overloading of rabbit knees in vivo. Acta Orthop Scand 1978;49:519-28.

-Dinges HP, Redl $H_{1}$ Thurner M, Schiesser A and Schlag. Morphometric studies on wound healing after systemic administration of an adriamycine and local application of fibrin sealant. Application of a new wound healing model using spongiosa implants. Pathol. Res.Pract. 1986;181:746.

-Dzioba RB. The classification and treatment of acute articular cartilage lesions. Arthroscopy 1988;4(2): 72-81. 
-Engkvist $\mathrm{O}$; Ohisen $\mathrm{L}$, Johansson $S$ and Skoog T. Reconstruction of articular cartilage using autologous perichondrial grafts. A preliminary report. Scand J Plast Reconstr Surg 1975;9:203.

-Engkvist O, Skoog T, Pastacaldi P, Yormuk E and Juhlin R. The cartilaginous potential of the perichondrium in rabbit ear and rib. Scand J Plast Reconstr Surg 1979:13:275-80.

-Engkvist $O$ and Wilander $E$. Formation of cartilage from rib perichondrium grafted to an articular cartilage defect in the femoral condyle of the rabbit. Scand J Plast Reconstr Surg 1979;13:371-6.

-Engkvist $O$ and Ohlsén $L$. Reconstruction of articular cartilage with free autologous perichondrial grafts. Scand J Plast Reconstr Surg 1979;13:26974.

-Engkvist $\mathrm{O}$ and Johansson SH. Perichondrial arthroplasty. A clinical study in 26 patients. Scand J Plast Reconstr Surg 1980;14:71-87.

-Erronen I, Videman T, Friman C and Michelsson J-E. Glycosaminoglycan metabolism in experimental osteoarthrosis caused by immobilization. Acta Orthop Scand 1978:49:329-34.

-Fawn HT and Landells JW. Histological studies of rheumatic conditions. I.Observations on the fine structure of the matrix of normal bone and cartilage. Ann Rheum Dis 1953;12:105-13.

-Fell HB. The osteogenic capacity in vitro of periosteum and endosteum isolated from the limb skeleton of fowl embryos and young chicks. J Anat 1932;66:157-80.

-Ficat $P$. Ficat $C$ and Gédéon P. Arthrose post-traumatique et chondrose post-contusive. Revue de Chirurgie orthop 1978;64:19-34.

-Finsterbush A and Friedmann B. Early changes in immobilized rabbits knee joints: A light and electron microscopic study. Clin Orthop Rel Res 1973;92:305-19.

-Fisher AGT. Physiological principles underlying the treatment of injuries and diseases of the articulations. Lancet 1923;1:541-8.

-Fuller JA and Ghadially FN. Ultrastructural observations on surgically produced partial-thickness defects in articular cartilage. Clin Orthop 1972;86:193-205. 
-Furukawa T, Eyre DR, Koide S and Glimcher MJ. Biochemical studies on repair cartilage resurfacing experimental defects in the rabbit knee. J Bone Joint Surg 1980;62-A:79-89.

-Ghadially FN, Thomas I, Oryschak AF and LaRonde JM. Long term results of partial -thickness defects in articular cartilage. A scanning electron microscope study. J Pathol 1977;121:213-7.

-Giebel $G$ and Rimpler M. Klebungen am Skeletsystem: Klebstoffe, 50 Jahre Hilfstoffe für den Chirurgen (Teil I). Biomed Tech 1981;86:35.

-Gillquist J, Hagberg $G$ and Oretorp.N. Arthroscopy in acute injuries of the knee joint. Acta Orthop Scand 1977;48:190-6.

-Glückert K und Weselch $\mathrm{G}$. Verlaufsbeobachtungen osteochondraler Fracturen mit Fibrinekleber; in Fibrinekleber in Orthopadie und Traumatologie; Ed. Cotta und Braun p.155-7. Georg Thieme Verlag Stuttgart New-York 1982.

-Haas SL. Regeneration of cartilage and bone with a special study of these processes as they occur at the chondrocostal junction. Surg Gynaec and Obst 1914;19:604-27.

-Hall BK. Hypoxia and differentation of cartilage and bone from common germinal cells in vitro. Life Sci 1969; 553-58.

-Hamblen DL and Carter RL. Sarcoma and joint replacement (editorial). J Bone Joint Surg 1984;66-B:625-27.

-Helbing $G$ und Burri C. Der Fibrinerklebung bei der Chondrocyten Transplantation. In Cotta $\mathrm{H}$ und Braun A (ed): Fibrinkleber in Orthopadie und Traumatologie. Georg Thieme Verlag Stuttgart. New York 1982, p.153-4.

-Hernborg JS and Nilsson BE. The natural course of untreated osteoarthritis of the knee. Clin Orthop 1977;123:130-7.1977.

-Hjerquist S-O and Lempberg R. Transplantation of autologous costal cartilage to an osteochondral defect on the femoral head. Virchows Arch Abt Path Anat. 1969;346:345-60.

-Homminga GN, van der Linden AJ, Terwindt-Rouwenhorst EAW and Drukker J. Repair of articular defects by perichondrial grafts: experiments in the rabbit. Acta Orthop Scand 1989;60:326-30. 
-Honner $\mathrm{R}$ and Thompson RC. The nutritional pathways of articular cartilage. J Bone Joint Surg 1971;53-A(4):742-48.

Hopkinson WJ, Mitchell WA and Curl WW. Chondral fractures of the knee. Cause for confusion. Am J Sports Med 1985; voll3(5):309

- Hvid I and Andersen LI. Perichondrial autograft in traumatic chondromalacia patellae. Acta Orthop Scand 1981;52:91-3.

-Ito LK. The nutrition of articular cartilage and its method of repair. British $\mathrm{J}$ Surg 1924; Vol 12:31-42.

-Jackson IT, Sully L, Tanner NSB and McGlynn MJ. An interpositional elastomeric cup for metacarpophalangeal joint perichondrioplasty in rheumatoid arthritis. Hand 1981;13:58-63.

-Johansson $\mathrm{H}$ and Engkvist $\mathrm{O}$. Small joint reconstruction by perichondrial arthroplasty. Clin Plast Surg 1981;8:107-14.

-Johnson-Nurse C and Dandy DJ. Fracture separation of articular cartilage in the adult knee. J Bone J Surg 1985;67-B(1):42-3.

-Joseph $\mathrm{J}$ and Dyson $\mathrm{M}$. Tissue replacement in the rabbits ear. J Bone Joint Surg 1966;53-B:372-80.

-Keller J, Andreassen TT, Joyce F, Knudsen VE, Jorgensen PH and Lucht U. Fixation of osteochondral fractures. Fibrin sealant tested in dogs. Acta Orthop Scand 1985;56:323-6.

-Kennedy JC. Grainger RW and Mcgraw RW. Osteochondral fractures of the femoral condyles. J Bone J Surg (Br) 1966;48-B:437-40.

-Kempson GE. Mechanical properties of articular cartilage. In "Adult articular cartilage" edited by MAR Freeman. Pitman Medical Publishing 2th ed. 1979;pp333.

-Kolliker A. Manual of human histology. Sydenham Society (London) $1853 ; 1: 59$.

-Kon M. Cartilage formation from perichondrium in a weight-bearing joint. Eur Surg Res 1981;13:387-96.

-Kulick MI, Brent B and Ross J. Free perichondrial graft from the ear to the knee in rabbits. J Hand Surg 1984:9A:213-15. 
-Landells JW. The reactions of injured human articular cartilage. J Bone Joint Surg 1957;39-B:548-62.

-Lane $J M_{1}$ Brighton $C T$, Ottens HR and Lipton $M$. Joint resurfacing in the rabbit using an autologous osteochondral graft. J Bone Joint Surg 1977;59$A(2): 218$

-Leidy J. On the intimate structure and histology of the articular cartilage. Am J Med Sci(N.S.) 1849;17:277-94.

-Lester CW. Tissue replacement after subperichondrial resection of costal cartilage: two case reports. Plast Reconstr Surg 1959;23:49-52.

-Lindahl O. Uber den Wassergehalt des Knorpels. Acta Orthop Scand 1948;17:134-42.

- Luxembourger MM, Malkani K and Rebel A. Etude au microscope électronique de la région de la transition entre le périchondrium et le cartilage de la plaque epiphysaire chez le foetus de cobaye. Arch d'Anat microscop 1974;63, no 2:117-32.

- Maltesta R. Uber Knorpelheilung nach aseptischen Verletzungen am hyalinen, von Perichondrium überzogenen, fertigen Knorpel, Virchow's Arch. f. path. Anat., etc., Berl., 1906, clxxiv, 123-37.

- Mankin HJ and Lippiello L. Biochemical and metabolic abnormalities in articular cartilage from osteo-arthritic human hips. J Bone J Surg 1970;52A:424-34.

-Marmor L. Unicompartimental knee arthroplasty: Ten to 13-year follow-up study. Clin Orthop Rell Res 1988;226:14-20.

- Maruyama $Y$. An experimental study on cartilage induction in autogenous perichondrial transplantation in rabbits. Keio J Med 1979;28:49-61.

-Maruyama $Y$. An experimental study on cartilage formation in autogenous perichondrial transplantation in rabbits. Kei $J$ med 1979;28:63-72.

-Maruyama Y. Clinical study on cartilage formation in autogenous perichondrial transplantation in plastic surgery. Keio $J$ Med 1979;28:49-61.

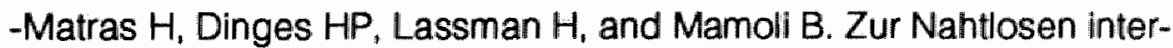
faszikularen Nerventransplantation im Tierexperiment. Wien Med. Wochenschr.1972;122:517. 
-Matsuoka M. Die Regeneration des Knorpelgewebes. Virchow's Arch. f. path. Anat, ect., Berl., 1904;clxxv:32.

-Matthewson MH and Dandy DJ. Osteochondral fractures of the lateral femoral condyle. J Bone Joint Surg (Br) 1978;60:199.

-McDermott AGP, Langer F, Pritzker KPH and Gross AE. Fresh-small fragment osteochondral allografts. Long-term follow-up study on first 100 cases. Clin Orthop Rel Res 1985;197:96-102.

- Meyers MH and Herron M. A fibrin adhesive seal for the repair of osteochondral fracture fragments. Clin Orthop 1984;182:258-63.

-Minns RJ, Muckle DS and Donkin JE. The repair of osteochondral defects in osteoarthritic rabbit knees by the use of carbon fibre. Biomaterials 1982; Vol 3:81-6.

-Mitchell $N$ and Shepard $N$. The resurfacing of adult rabbit articular cartilage by multiple perforation through the subchondral bone. J Bone Joint Surg 1976;58-A:23-33.

-Morscher E. Traumatische Knorpellasionen am Kniegelenk. Chirurg 1979;50:599-604.

-Nelson $\mathrm{BH}$, Anderson DD, Brand $\mathrm{R}$ and Brown TD. Effect of osteochondral defects of articular cartilage. Contact pressure studies in dog knees. Acta Orthop Scand 1988;59(5):574-9.

-Niedermann B, Boe S, Lauritzen J and Rubak JM. Glued periosteal grafts in the knee. Acta Orthop Scand 1985;56:457-60.

-Oakshott RD, Farine I, Pritzker KPH, Langer F and Gross AE. A clinical and histologic analysis of failed fresh osteochondral allografts. Clin Orthop Rel Res 1988;223:283-94.

-O'Donoghue $\mathrm{DH}$. Chondral and osteochondral fractures. The Journal of Trauma 1966; vol 6(4):469-81.

-O'Driscoll SW and Salter RB. The induction of neochondrogenesis in free intra-articular periosteal autografts under the influence of continuous passive motion. J Bone Joint Surg 1984;vol 66-A, no 8:1248-57.

-O'Driscoll SW, Salter RB and Keeley FW. A method of quantative analysis of ratios of types I and II collagen in small samples of articular cartilage. Analytic Biochemistry 1985;145:277-85. 
-O'Driscoll SW, Keeley FW and Salter RB. Durability of regenerated articular cartilage by free autogenous periostal grafts in major full-thickness defects in joint surfaces under the influence of continuous passive motion. J Bone Joint Surg 1988;70-A(4):595-606.

-Ohlsén $L$ and de la Fuente A. Reconstruction del cartilago articular mediante injertos libres de perichondrio: estudio experimental. Rev Quir Espan $1976 ; 3: 4$.

-Ohisén L. Cartilage formation from free perichondrial grafts: an experimental study in rabbits. Br J Plast Surg 1976;29:262-7.

-Ohisén L. Cartilage regeneration from perichondrium. Plast Reconstr Surg 1978;4(62):507-13.

-Ohlsén $L$ and Widenfalk B. The early development of articular cartilage after perichondrial grafting. Scand J Plast Reconstr Surg 1983;17:163-77.

-Olijhoek G, Drukker J, van der Linden AJ and Terwindt-Rouwenhorst EAW. Drug effect on arthrosis-comparison in rabbits of 3 mode action. Acta Orthop Scand.1988;59:186-90.

-Outerbridge RE. The etiology of chondromalacia patellae. J Bone Joint Surg 1961;43-B:752-5.

-Paar $O$, Bernett $P$ und Erhardt $W$. Versorgung chondraler und osteochondraler Fracturen am Knie und oberen Sprunggelenk mit Fibrinekleber; in: Fibrinklebung; Ed. J. Scheele p.193-7. Springer Verlag Berlin Heidelberg New York Tokyo 1984.

-Paget. Healing on injuries in various tissues. Lectures on surgical pathology 1853. Voll.I, Lexture XII, 262.

-Passl R, Plenk H, Sauer G, Sprangler HP and Radaskiewcz T. Die homololge reine Gelenkknorpeltransplantation im Tierexperiment. Arch.Orthop.Unfall-chir 1976;86:243-56.

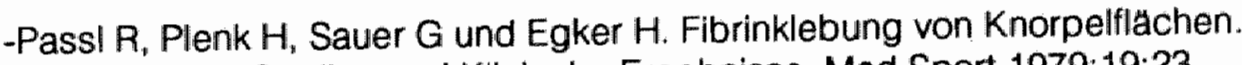
Experimentele Studien und Klinische Ergebnisse. Med Sport 1979;19:23.

-Pastacaldi $P$ and Engkvist $O$. Perichondrial arthroplasty in rheumatoid patients. Hand 1979;1l:184-90.

-Peer LA. Transplantation of tissues Vol. I 1955. Williams and Wilkins. Baltimor. 
-Plenk H und PassI R. Trans and replantation of articular cartilage using the fibrin adhesive system. In Gastper(ed): Biology of the articular cartilage in Health and Disease: Proceedings of the second Munich Symposion on Biology of connective tissue. New York, Schattauer 1981, p 439.

-Pridie $\mathrm{KH}$. A method for resurfacing osteoarthritic knee joints. J Bone Joint Surg 1959;41-B:618.

-Puhl W and Dustmann HO. Die Reaktionen des Gelenkknorpels auf Verletzungen. Z Orthop 1973;111:494-7.

-Radin EL, Paul IL and Lowy M. A comparison of the dynamic force transmitting properties of bone and articular cartilage. J BOne J Surg 1970;52A:444-56.

-Radin EL, Ehrlich MG, Chernak R, Abernethy P. Paul IL and Rose RM. Effect of repetitive impuls loading on the knee joints of rabbits. Clin Orthop 1978;131:28-93.

-Radin EL and Rose RM. Role of subchondral bone in the initiation and progression of cartilage damage. Clin Orthop Rel Res 1986;213:34-40.

-Ranawat CS, Insall $\mathrm{J}$ and Shine J. Duo-condylar knee arthroplasty. Clin Orthop Rel Res 1976;120:77-82.

-Redfern P. On the healing of wounds in articular cartilage (1851). Reprinted in Clin Orthop Rel Res 1969;64:4-6.

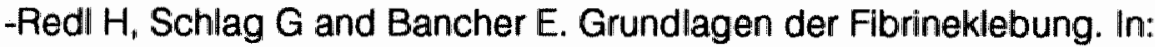
Fibrinekleber in Orthopadie und Traumatologie 4. Heidelberger Orthopadie Symposium. H. Cotta/ A. Braun(Ed.) Georg Thieme Verlag 1982:18-21.

-Ritsila $V$ and Alhopuro S. Regeneration of articular cartilage defects with free perichondrial grafts. IRCS Medical Science. Connective Tissue, Skin and Bone; Surgery and Transplantation 1975;3:49-50.

-Rosenberg $\mathrm{NJ}$. Osteochondral fractures of the lateral femoral condyle. $J$ Bone Joint Surg 1964;46-A:1013.

-Rosenberg $L$. Chemical basis for biological use of safranin 0 in the study of articular cartilage. J Bone Joint Surg 1971:53A:69-82.

-Rubak JM, Poussa M and Ritsila V. Effects of joint motion on the repair of articular cartilage with free periosteal grafts. Acta Orthop Scand 1982;53:187-91. 
-Rubak JM, Poussa $M$ and Ritsila V. Chondrogenesis in repair of articular cartilage defects by free periosteal grafts in rabbits. Acta Orthop Scand 1982;53:181-6.

-Rupp G und Stemberger A. Fibrinklebung in der Orthopadie. Med Welt 1978;18:768-9.

-Salter RB, Simmons DF, Malcolm BW, Rumble DJ, McMichael Douglas and Clements ND. The biological effect of continuous passive motion on the healing of full-thickness defects in articular cartilage. An experimental investigation in the rabbit. J Bone Joint Surg 1980;62-A:1232-51.

-Sandberg $R$ and Balkfors $B$. Reconstruction of the anterior cruciate ligament. A 5-year follow-up of 89 patients. Acta Orthop Scand 1988;59(3):28893.

-Scheele J, Schricker KTh, Goy RD, Lampe / und Panis R. Hepatitisrisiko der Fibrinklebung in der Algemeinchirurgie. Med Welt 1981;32:783-8.

-Scheele J und Pesch HJ. Morphologische Aspekte des Fibrinekleberabbaues im Tierexperiment. In $\mathrm{H}$ Cotta und A Braun, Fibrinekleber in Orthopadie und Traumatologie p35-43. Thieme Stuttgart 1982.

-Schlag G and Redl H. Fibrin sealant in orthopedic surgery. Clin Orthop Rel Res 1988;227:269-85.

-Seradge $H$, Kutz JA, Kleinert HE, Lister GD, Wolff TW and Atasoy E. Perichondrial resurfacing arthroplasty in the hand. J Hand Surg 1984; Vol 9A,6:880-6.

-Shands Ar. The regeneration of cartilage in joints. Arch Surg 1931:22:13778.

-Simmons DP and Chrismann OD. Salicylate inhibition of cartilage degeneration. Arthritis Rheum 1965;8:960-9.

-Skoog T, Ohisen L and Sohn SA. Perichondrial potential for cartilagenous regeneration. Scand J Plast Reconstr Surg 1972;6:123-5.

-Skoog T. Plastic Surgery. New methods and refinements. Almqvist and Wiksell International, Stockholm, and W.B. Saunders, Philadelphia, 1974.

-Skoog T and Johansson SH. Nytt ledbrosk fran transplanterat perikondrium. Lakartidningen 1975;72(12):1789-92. 
-Skoog T, Ohisen L and Sohn SA. The chondrogenic potential of perichondrium. Chir.plastica(Berl) 1975;3:91-103.

-Skoog $\mathrm{T}$ and Johanisson $\mathrm{SH}$. The formation of articular cartilage from free perichondrial grafts. Plast Reconstr Surg 1976:57:1.

-Sohn SA and Ohlsen L. Growth of cartilage from a free perichondrial graft placed across a defect in a rabbits trachea. Plast Reconstr Surg $1974 ; 53(1): 55-60$.

-Speer DP, Chvapil M, Volz RG and Holmes MD. Enhancement of healing of osteochondral defects by collagen sponse implants. Clin Orthop $1979 ; 144: 326-35$.

-Staind $O$ and Galvan $O$. Zur Resorption des Fibrinklebers nach plastischen Operationen im Gesichtsbereich. Eine Untersuchung mit radio-aktiven Isotopen. In H Cotta und A Braun; Fibrinekleber in Orthopadie und Traumatologie p.11-14. Thieme Stuttgart 1982.

-Stockwell RA. Biology of cartilage cells. Cambridge University Press 1977.

-Streeter GL. Development horizons in human embryos. A review of the histogenesis of cartilage and bone 1949;220:149-67.

-Sully L, Jackson IT and Somerlad BC. Perichondrial grafting in rheumatoid metacarpophalangeal joint. Hand 1980;12:137-48.

-Tajima S, Aoyagi F and Maruyma Y. Free perichondrial grafting in the treatment of temporomandibular joint ankylosis. Plast Reconstr Surg 1978;61(6):877-80.

- Tanaka $\mathrm{H}$ and Shinno $\mathrm{N}$. Histochemical studies on regeneration of articular cartilage. Tok J Exp Med 1971;18:63-73.

-Terry GC, Flandry F, Van Manen JW and Norwood LA. Isolated chondral fractures of the knee. Clin Orthop Rel Res 1988; $\quad 234: 170-8$.

-Tizzoni. Archiv per le scienze mediche 1878; T II:28.

-Upton J, Sohn SA and Glowack J. Neocartilage derived from transplanted perichondrium: what is it? Plast Reconstr Surg 1981; Vol 68(2):166-72.

-Wasteson A and Ohlsen L. Biosynthesis of chondroitin sulphate in cartilage regenerated from perichondrium. Scand J Plast Reconstr Surg 1977;11:1722. 
- Weber SC and Chapman MW. Adhesives in orthopaedic surgery. A review of the literature and in vitro bonding strengths of bone-bonding agents. Clin Orthop Rel Res 1983;191:249-62.

- Wiberg G. Roentgenographic and Anatomic studies on the femoropatellar joint. With special reference to chondromalacia patellae. Acta Orthop Scand 1941;12:319-410.

-Widenfalk B, Engkvist $O$ and Segerstrom K. Perichondrial arthroplasty using fibrin glue and early immobilization. Scand J Plast Reconst Surg 1986;20:251-8.

-Wilbrand $\mathrm{H}$ and Engkvist $\mathrm{O}$. Radiography in joint reconstruction with perichondrial grafts. Acta Radiologica Diagnosis 1979;20:967-76.

-Woo SL-Y, Kwan MK, Lee TQ, Field FP, Kleiner JB and Coutts RD. Perichondrial autograf for articular cartilage. Shear modulus of neocartilage studied in rabbits. Acta Orthop Scand 1987;58:510-15.

-Young $J Z$ and Medawar PB. Fibrin suture of peripheral nervus. Lancet $1940 ; 1: 126$.

-Zilch $\mathrm{H}$. Tierexperimentelle Untersuchungen zur Klebung kleiner osteochondraler Fragmente mit dem Fibrinekleber. Handchirurgie 1980:12:71-5.

-Zilch $\mathrm{H}$ and Friedebold $\mathrm{G}$. Klebung und osteochondraler Fragmente und Fixierung von Dissecaten bei der Osteochondrosis dissecans. In: Fibrinekleber in Orthopadie und Traumatologie. Ed. H.Cotta and A.Braun p.142-145. Georg Thieme Verlag Stuttgart-New York 1982.

-Zilch $\mathrm{H}$ and Wollf $\mathrm{R}$. Fibrinekleber und Knochenneubildung. Z Orthop $1987 ; 125: 214-8$. 


\section{ACKNOWLEDGEMENTS}

This study was initiated by professor dr. A.J. van der Linden, my teacher in orthopedics from 1985 to 1990 . The animal experiments were carried out in the centralized experimental animal facilities department of the biomedical centre of the Rijks Universiteit Limburg (head: A.E.J.M. van den Bogaard). The preparation of the histological specimens was done in the department of Anatomy and Embryology (head: Professor dr. J.Drukker) by Mrs. E. Terwindt-Rouwénhorst. Dr. R. Kuyer, formerly assigned to the Jan van Breemen Instituut in Amsterdam as a biochemist, did the chemical analysis. Sjoerd Bulstra, orthopedic surgeon, was always there to discuss problems with. He developed a very useful culture system to carry out the experiments with the perichondrial explants. My colleagues of the department of orthopedics of the Academisch Ziekenhuis Maastricht stimulated and encouraged me during the experimental and clinical phase of the study. The nursing staff of the out patient department, the theatre and the orthopedic ward were open minded and helpful when this new technique was introduced. The staff of the department of physiotherapy (head: $\mathrm{mr}$. G. $M$. Rooks) showed a great interest in and participated fully in the rehabilitation program of the patients. The staff of the audiovisual department of the hospital made photographs during the operations and adjusted them for publication. Mr. Guus van Rooy, graphic designer of the audiovisual department of the Rijks Universiteit Limburg, made the drawings, designed the cover page and took care of the lay-out. Miss Phianne Bouwmeester, medical student, put all the data into the computer and made them available for analysis. Drs. A.D.M. Kersten, staff member of the department of Informatica of the Rijks Universiteit Limburg, adviced me for the statistical analysis of the patients data. Mrs Tineke Homminga translated the manuscript into English. Mrs Marjon Bastings typed out the text.

I am very gratefull to all the persons mentioned; they were a great help in completing this study. 


\section{CURRICULUM VITAE}

The author, George Nicolaas Homminga, was born on the 14th of August 1952 in Franeker, The Netherlands. He attended the Roman Catholic Elementary school. In 1964 he started secondary school in Megen (NoordBrabant) and finished the last three years of the Gymnasium beta education on the Boschveld college in Venray. He attended medical school on the Rijks Universiteit in Groningen from 1970 to 1978. During that time he worked one year as a student assistent in the department of experimental anaesthesiology (head: Prof. dr. J.C. Dorlas). From may 1978 to october 1979 he was a junior house officer in the department of general surgery of the Diaconessen Ziekenhuis in Groningen and for one year in The Tjongerschans Ziekenhuis in Heerenveen. For three months he followed a course in tropical medicine at The Tropen Instituut in Amsterdam and left the country to work for three years as a medical officer in a rural hospital in Ghana: The St.Anthony's Hospital in Dzodze (Volta Region). During this time he was especially assigned for the treatment and rehabilitation of children with disabilities due to poliomyelitis. From March to October 1983 he worked in the cardiosurgical centre of the Academisch Ziekenhuis Utrecht (head: Prof. dr. J.F. Hitchcock).

From that time to August 1985 he fulfilled his residency in general surgery in the Prinses Irene Ziekenhuis in Almelo (head: dr. O.Kluft). In the department of Orthopedics in the Academisch Ziekenhuis Maastricht (head: Prof.dr. A.J.van der Linden) he completed his training to orthopedic surgeon. During this time he was given the opportunity to perform this study. From october 1989 he is assigned at the Canisius-Wilhelmina Zlekenhuis in Nijmegen as an orthopedic surgeon. 